Universidad de Lima

Facultad de Comunicación

Carrera de Comunicación

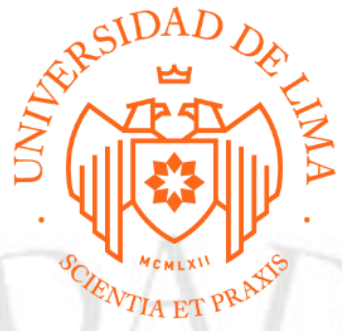

\title{
CONDOMINIO: VILLA DEL ATLETA, UN PLAN DE COMUNICACIÓN DISPUESTO A CONSEGUIR SU VENTA TOTAL
}

Trabajo de Suficiencia Profesional para optar el Título Profesional de Licenciado en Comunicación

\section{Andrea Barandiarán Hidalgo}

Código 20130116

$$
\text { Lima - Perú }
$$

Octubre del 2019 


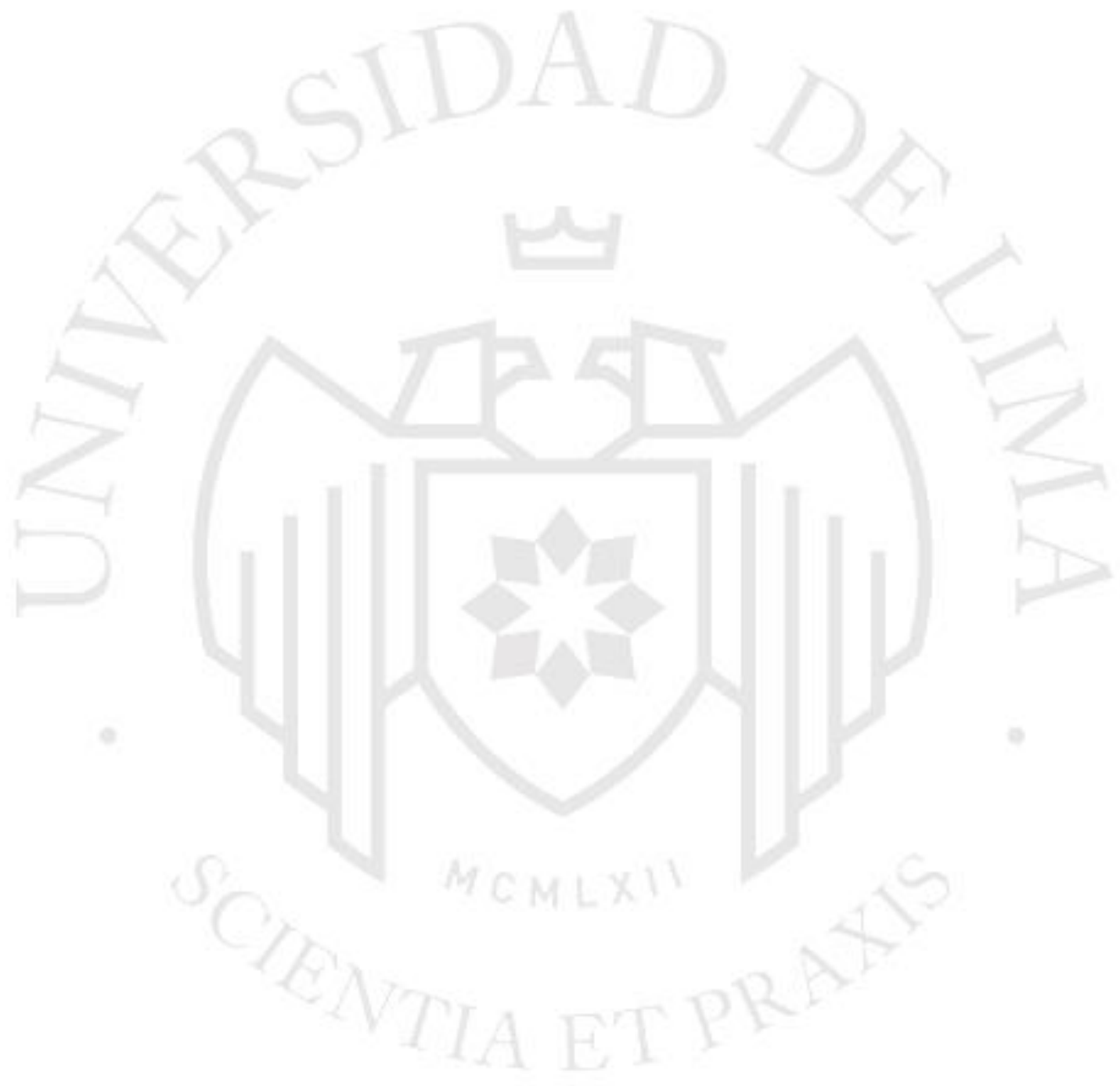




\section{CONDOMINIO: VILLA DEL ATLETA, UN PLAN DE COMUNICACIÓN DISPUESTO A CONSEGUIR SU VENTA TOTAL}




\section{ÍNDICE}

RESUMEN

INTRODUCCIÓN.................................................................................

1. ANTECEDENTES DEL TRABAJO_.......................................10

1.1. CONTEXTO POLÍTICO: ..................................................... 10

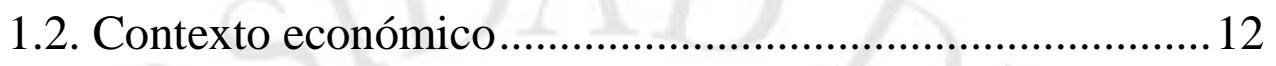

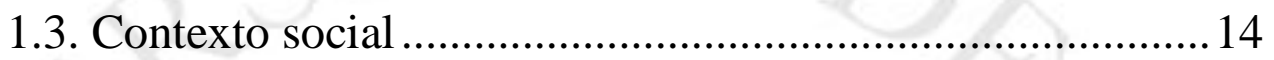

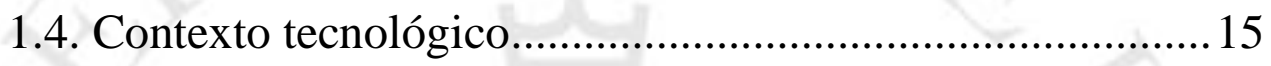

2. HALLAZGOS CLAVES ............................................................................16

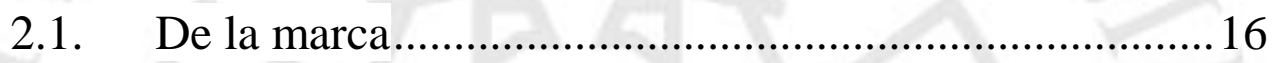

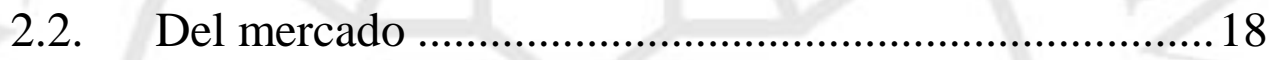

2.3. De la competencia................................. 22

2.3.2. Competencia Directa ........................................................232

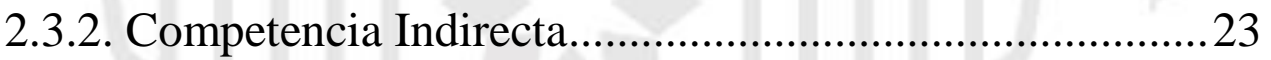

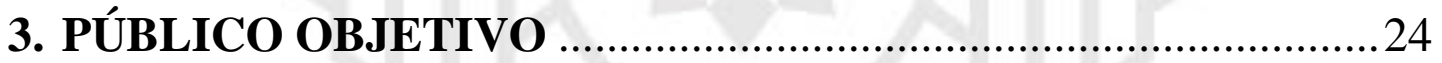

3.1. Perfil económico y demográfico: ..................................24

3.2. Perfil Social de Interés (ama de casa y jefe del hogar): 24

3.3. Perfil del adulto joven (21-35 años):...............................25

3.4. Perfil del internauta de Lima Sur .................................25

3.5. Perfil del usuario de medios de Lima Sur .....................26

3.6. Encuestas a público objetivo ........................................27

\section{LA MARCA.}

¡Error! Marcador no definido.

4.1. Posicionamiento del Condominio Villa del Atleta ........34

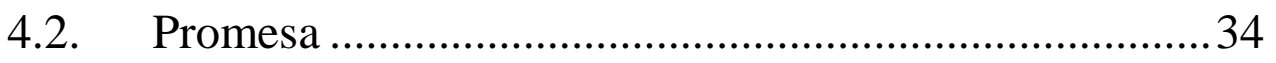

4.3. Ventaja Diferencial.........................................................34 


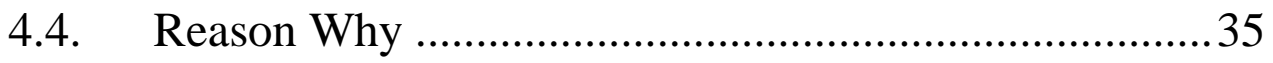

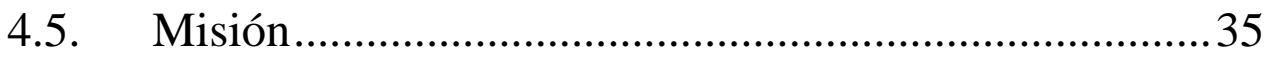

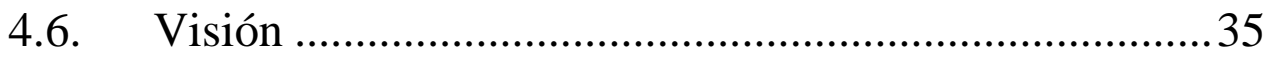

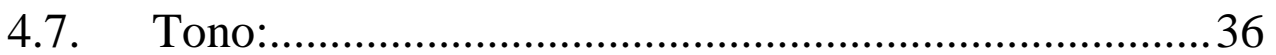

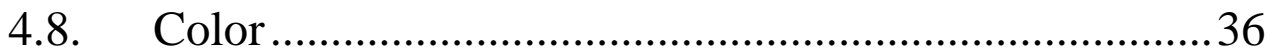

5. MANUAL DE IDENTIDAD CORPORATIVO .................35

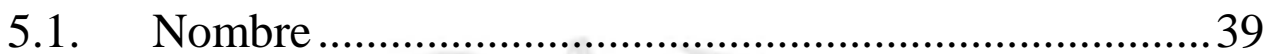

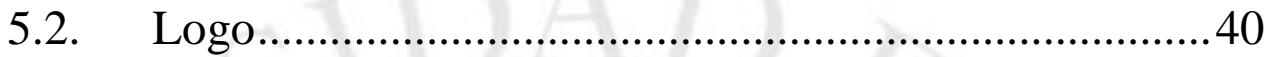

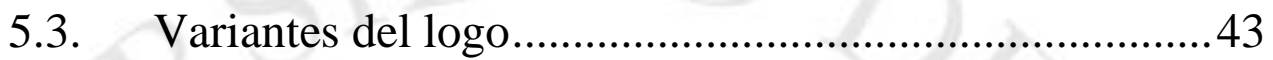

5.4. Variantes del logo en positivo y negativo ...................... 44

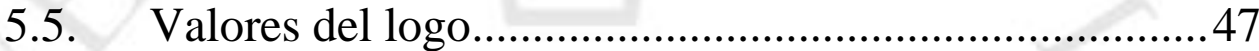

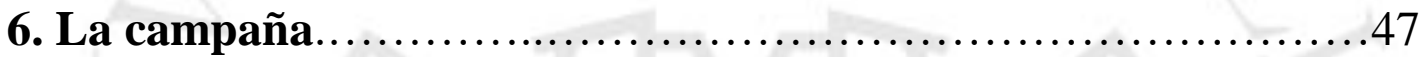

7. ETAPAS DE LA CAMPAÑA .................................47

8. SUSTENTACIÓN DE PRESUPUESTO ..........................................71

9. CONCLUSIONES ..........................................56

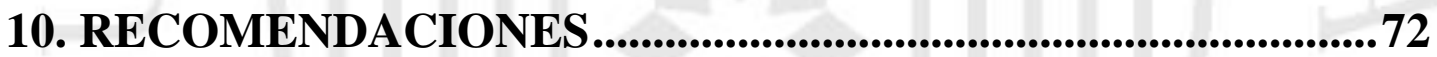

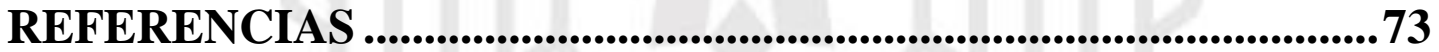

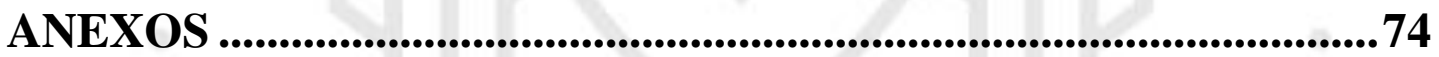




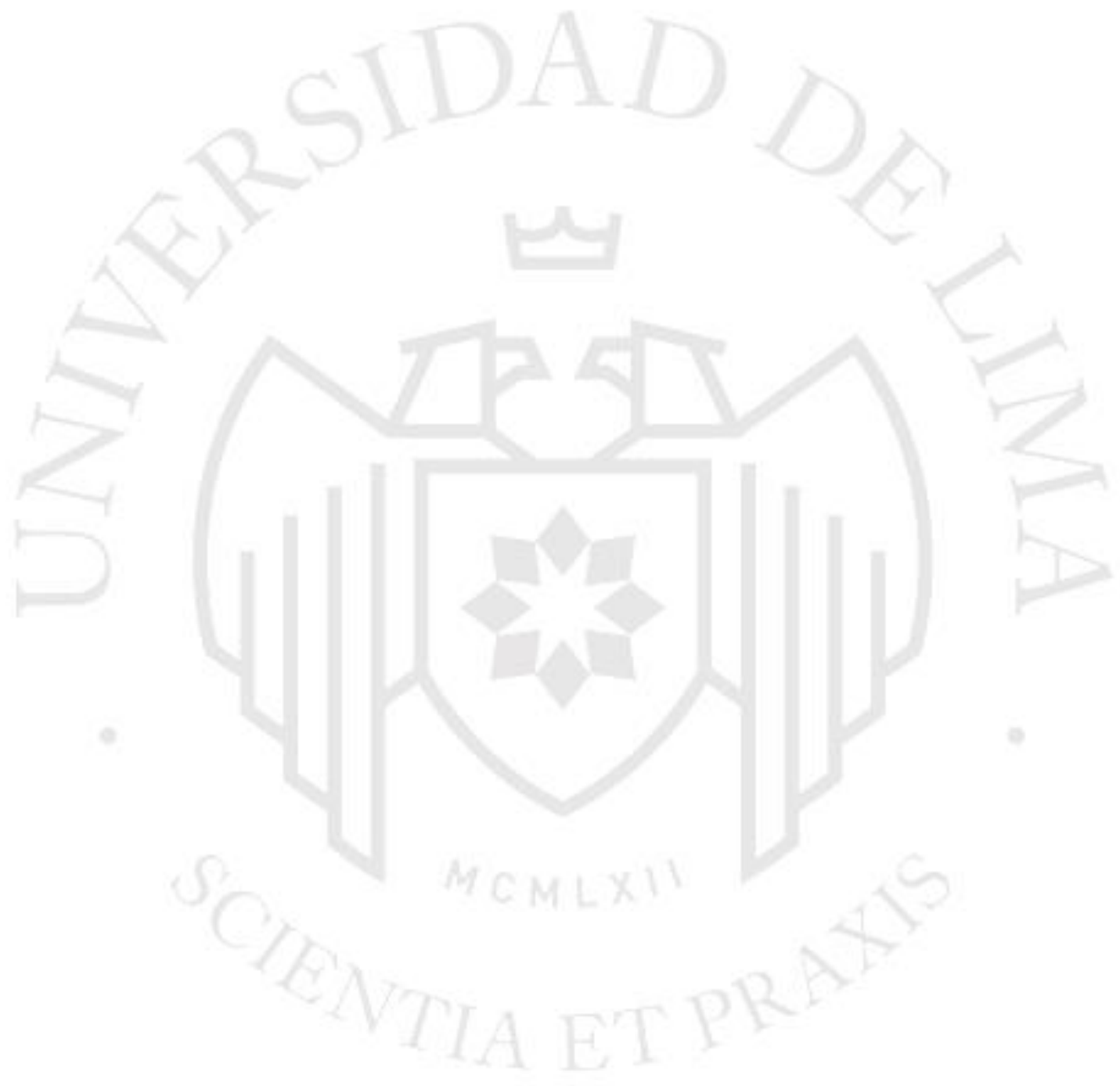




\section{Dirección web de piezas de comunicación:}

https://drive.google.com/open?id=1 otUKSm5YFjyPfraY1aK9tLiCq38aEw6o

\section{Dirección web de tablas de excel:}

https://drive.google.com/open?id=1T2-JxWw3BFJMLa-UAysEOXPdhoOkOk4q 


\section{RESUMEN}

En este trabajo se desarrollará la campaña de comunicación integral y la identidad corporativa del Condominio: Villa del Atleta, edificado, en su momento, para albergar a los deportistas que participaron en los Juegos Panamericanos y Parapanamericanos 2019. En la actualidad, terminados los juegos, se busca tener una campaña efectiva y vender el $100 \%$ de los departamentos del Condominio, ubicado en Villa el Salvador, orientado hacia a un público del NSE C y D.

Palabras clave: marketing, digital, identidad corporativa, segmentación, neuromarketing, marketing inmobiliario 


\section{INTRODUCCIÓN}

A pocas semanas de haber finalizado los Juegos Panamericanos y los Juegos Parapanamericanos 2019 en nuestra ciudad de Lima, ha quedado el condominio: Villa del Atleta a la venta para los peruanos que deseen vivir en Villa el Salvador, lugar donde se ubican las 7 torres edificadas que albergaron numerosos deportistas.

Gracias a la coyuntura y el boom que produjo la llegada de los juegos, estos departamentos cuentan ahora con un posicionamiento marcado en la mente del potencial comprador. Entonces, nuestro objetivo consta de la venta al $100 \%$ de los departamentos restantes, descontando los que fueron otorgados a nuestros medallistas peruanos.

Asimismo, el proyecto conlleva la creación de una identidad corporativa que llame al target a adquirir estos departamentos. La campaña de comunicación integral deberá informar todos los detalles sobre los departamentos y cómo poder conseguirlos, propiciar el interés en el target y con ello conseguir vender todo el Condominio: Villa del Atleta. El planteamiento y ejecución del mix de medios ayudará a conseguir nuestra meta antes de finalizar el segundo trimestre del año 2020.

Como se trata de un financiamiento a través del programa nuevo crédito Mi Vivienda, la inmobiliaria Q'umir House, la cual posee un área de comunicaciones, se encargará de toda la producción de la identidad visual y el plan de marketing integral para llevarlo a cada medio a utilizar, desde lo digital, hasta lo offline. 


\section{ANTECEDENTES DEL TRABAJO}

Nuestra labor es analizar el contexto y los ámbitos que se relacionan con el negocio de compra-venta inmobiliaria, es por ello que contaremos con un análisis PEST antes de iniciar con el planeamiento del marketing integrado y la identidad corporativa del Condominio: Villa del Atleta.

\subsection{Contexto político:}

Para poder contextualizarnos en el ámbito político- legal, se debe tener en cuenta el fondo Mi Vivienda, creado en el año 1998, mediante el cual el target podrá ser acreedor de los departamentos. De acuerdo al Marco Legal del fondo hipotecario Mi Vivienda, se decretó la siguiente ley:

De acuerdo a la Ley $\mathrm{N}^{\circ} 28579$, el Fondo MIVIVIENDA S.A. se convierte en una empresa estatal de derecho privado, comprendido bajo el ámbito del Fondo Nacional de Financiamiento de la Actividad Empresarial del Estado - FONAFE y adscrito al Ministerio de Vivienda, Construcción y Saneamiento.

Este fondo tiene como finalidad propiciar un crédito de hasta el $90 \%$ del precio de la vivienda a quienes lo necesiten para poder cumplir el sueño de una casa o departamento propio. Este crédito otorga la facilidad de pagar en cuotas cómodas mensualmente, y así facilitar el proceso compra-venta para los peruanos que cumplan con los requisitos que establece el fondo, especificados en la imagen 1. 
¿Qué requisitos debo cumplir?

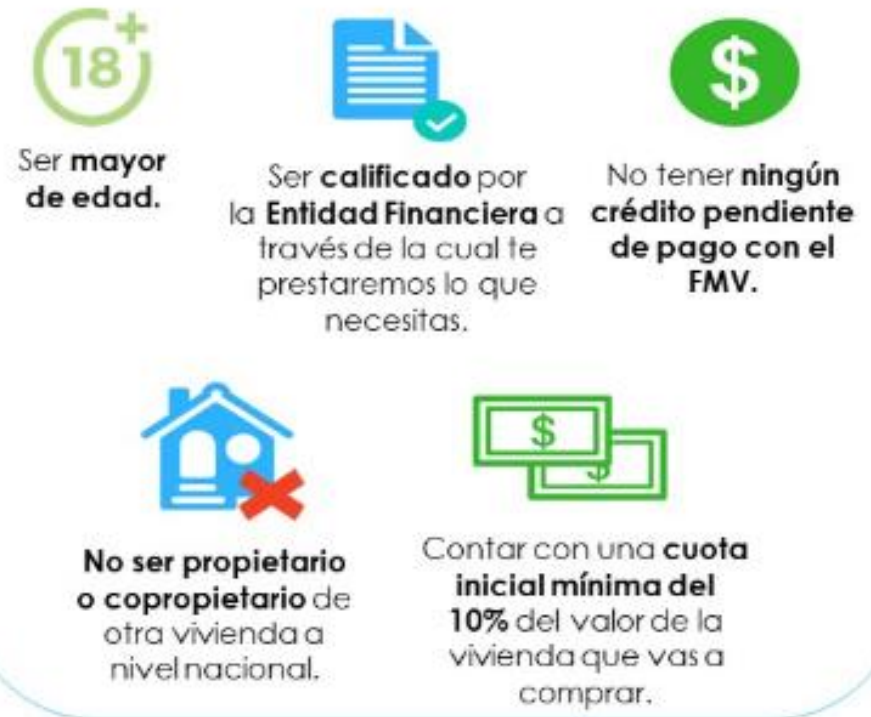

Imagen 1: Modalidades de Nuevo Crédito Mi Vivienda

Elaboración: Mi vivienda. Fuente: Portal Web Mi Vivienda

Cabe resaltar que estas viviendas tienen un rango de precio que no debe disminuir de S/ 58800 ni excederse de S/ 419600 con un plazo para completar todo el pago entre 5-20 años. Además, muy a parte de la ayuda económica que brinda en sí, el nuevo Crédito Mi Vivienda premia tu puntualidad en los pagos mensuales a través del "Bono del Buen Pagador", el cual otorga un descuento adicional a la cuota que pagas al mes.

Por otro lado, se debe tener en cuenta, que muy a pesar de que el Estado propone una facilidad para poder comprar un departamento, también, como peruanos, tenemos derecho a una vivienda. Es por ello que, la congresista Marisa Glave (2018) incorporó a la constitución política del Estado, el derecho a tener una vivienda digna en la Constitución Política del Perú. La siguiente ley expone:

Artículo 7.B.- Derecho a Vivienda Digna

El Estado reconoce y garantiza el derecho a una vivienda digna y adecuada, ello comprende el acceso a los servicios básicos e infraestructura pública necesaria. El Estado promueve las condiciones necesarias para hacer efectivo este derecho, mediante programas públicos y privados de vivienda de interés social y otros 
sistemas de financiamiento de programas de vivienda y urbanización, debiendo contar con la participación de los ciudadanos de acuerdo a ley.

Estas leyes permiten que la venta del Condominio sea factible y al mismo tiempo proporciona facilidades para aquellos que, en un primer momento, no conciben los montos totales de la compra.

Es importante también tener en cuenta que 300 de los 1096 departamentos del Condominio Villa del Atleta cuentan con una infraestructura totalmente inclusiva, que proporciona facilidades a discapacitados con lectura braille, barandas dentro de los baños, zonas mucho más anchas para poder transitar con silla de ruedas, etc.

\subsection{Contexto económico}

En la actualidad, la economía de nuestro país dirigida a bienes inmuebles y la demanda de compra de departamentos y/o casas, ha ido en aumento. Debido a que la demanda es aún mayor a la oferta, el BBVA Research de "Mercado de viviendas nuevas y oficinas prime en Lima", afirma los siguientes datos en este 2019 y años siguientes:

La demanda de departamentos excede la oferta actualmente disponible en el mercado limeño. En ese entorno, la oferta está respondiendo adecuándose gradualmente a las características de la demanda, como por ejemplo con departamentos más pequeños y de menor número de dormitorios. El Estado, por otra parte, viene induciendo (a través del bono verde) el desarrollo de proyectos que incorporen criterios de sostenibilidad ambiental.

Estimamos que las ventas de departamentos nuevos en Lima seguirán aumentando en 2019 y que alcanzarán entre 16500 unidades y 17000 unidades. En ello incidirá positivamente la mayor capacidad adquisitiva de la población (aumento del empleo formal), lo que facilitará el acceso de más familias al crédito hipotecario. Además, las tasas de interés seguirán siendo atractivas y los subsidios habitacionales ( por ejemplo el bono verde) continuarán apoyando el financiamiento de departamentos de ciertas características y precios. (2018) Se tiene la expectativa de que las ventas de 
departamentos nuevos en Lima sigan en aumento como se logró del 2017 al 2018 en un $13 \%$, como lo expone la tabla 1 de la imagen 2. Asimismo, según la segunda tabla de la Imagen 2, a mayor precio tenga el departamento, la compra aumenta, por lo cual el tema del precio no supondría un problema en cuanto a la venta de los departamentos de nuestro Condominio.

Imagen 2: Mercado de viviendas nuevas y oficinas prime en Lima

\section{Recuperación de las ventas de viviendas nuevas en Lima siguió consolidándose en $\mathbf{2 0 1 8}$, destacando el segmento de precios más altos}

Ventas de departamentos nuevos(1) (en unidades)

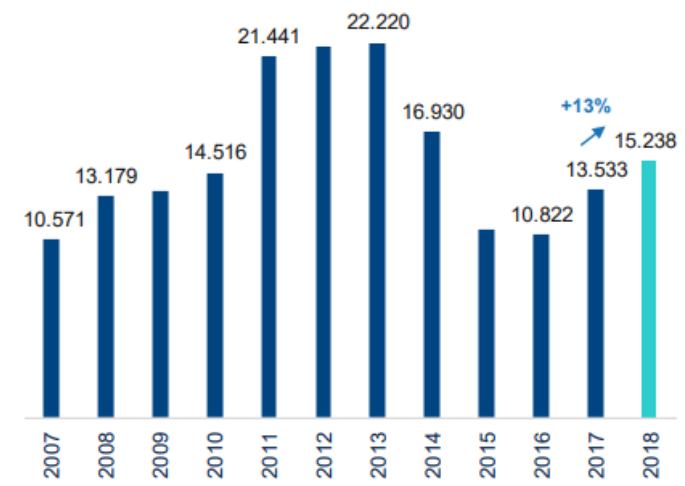

Incremento de las ventas de departamentos nuevos en 2018 según precio ${ }^{(1)}$ (en unidades)
(1) Comprende a 49 distritos de Lima-Callao. El $98 \%$ de
desde agosto del anoo previo hasta julio del ano en curso
Fuente: CAPECO y

Tabla 1

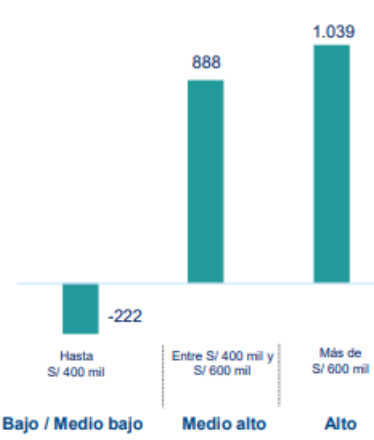

Alto

Tabla 2

Por otro lado, tengamos en cuenta un estudio del APEIM, sobre la distribución de gastos de los NSE C y D. Se puede observar en la Imagen 3 que un 13\% de los ingresos del NSE C y del D, son destinados a Vivienda. Aquello demuestra que estos sectores, incluidos dentro de nuestro target, sí invertirían en la compra de los departamentos del Condominio: Villa del Atleta y dispondrían de una cómoda cuota mensual para pagar el préstamo otorgado por el Nuevo Crédito Mi Vivienda. 


\section{Apeim}

\section{DISTRIBUCIÓN DEL GASTO SEGÚN NSE 2018 - LIMA METROPOLITANA}
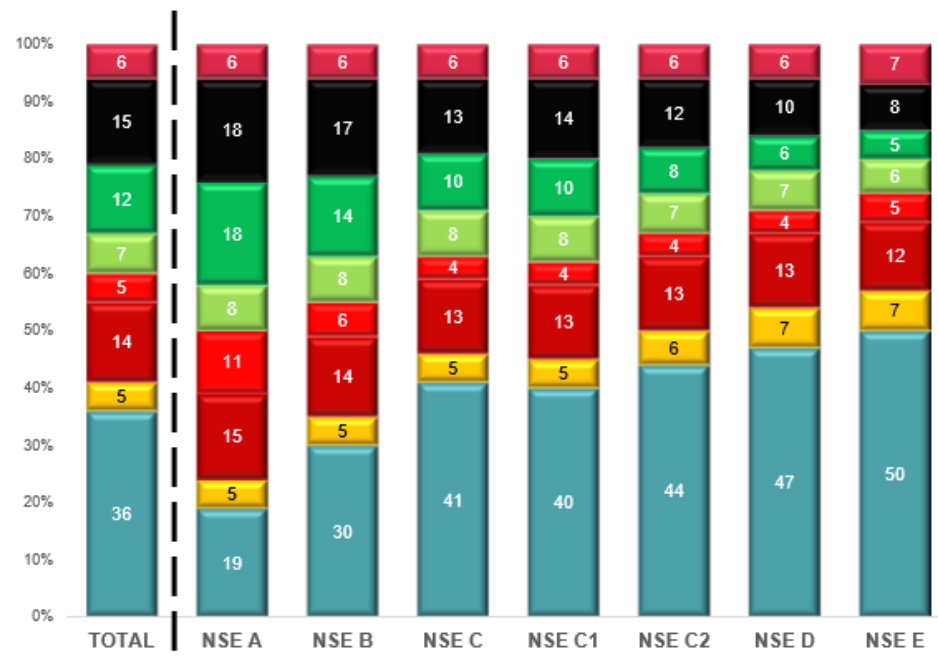

- Otros

- Educación

- Transporte

a Salud

- Muebles

- Vivienda

a Vestido

a Alimentos

\section{Fuente: APEIM 2018, p.g. 47.}

\subsection{Contexto social}

El Condominio Villa del Atleta, al ser un proyecto que debía albergar más de $7 \mathrm{mil}$ deportistas, conllevó la edificación de zonas deportivas en las que los competidores podían entrenar y realizar una rutina para llegar aptos a sus competencias. Tener un complejo habitacional con zonas que permitan a sus habitantes disponer de una vida saludable es pieza clave en la investigación. El condominio cuenta con un gimnasio y en su exterior tiene dos lozas deportivas instaladas, así como también, una vía de $1 \mathrm{~km}$ para bicicletas.

Cada año que pasa, los peruanos estamos adaptando un estilo de vida saludable y esto lo demuestran estudios como el DATUM Internacional. Basándonos en su estudio sobre "Vida Saludable ¿Yo?” encontramos que para la gran mayoría de peruanos la vida saludable es un concepto asociado con "comer sano" (68\%). Los limeños y citadinos lo asocian también con "hacer deporte" (58\%) lo cual estaría relacionado con salud física y "pasar tiempo con la familia" (56\%) que podría estar relacionado con la salud afectivaemocional. (2018) 
Ese $58 \%$ de limeños que relaciona una vida saludable a la salud física, entonces destaca los beneficios que ofrece el Condominio Villa del Atleta, puesto que preserva encontrarse en movimiento y realizar deportes a un paso de su vivienda. Asimismo, si nos basamos también en el dato que propone de que el $56 \%$ de los peruanos relaciona salud física con pasar tiempo en familia, entonces obtenemos un doble beneficio que puede aportar valor a nuestros potenciales compradores. El complejo habitacional cuenta con 3 salas multiusos, una sala de juego para jóvenes y una sala para niños. Dentro de nuestro plan de comunicación integrada, deberán resaltarse estas zonas que propician la unión y convivencia en familia y amigos.

\subsection{Contexto tecnológico}

El internet y las redes sociales han supuesto un cambio en el consumidor peruano y su forma de realizar sus actividades cotidianas. Según una nota del diario Correo, la Asociación de Empresas Inmobiliarias del Perú (ASEI) expone en el 2018 que "el $48.25 \%$ de los potenciales clientes recurren a portales inmobiliarios y ferias por internet para comprar un inmueble. Mientras que el 14\% recurre a redes sociales como Facebook o Instagram para enterarse de ofertas, promociones y planes de financiamiento. En tanto, solo el $11 \%$ recurre a la web de una determinada empresa inmobiliaria. Esto demuestra la importancia que han tomado los canales online como principal vía de venta de unidades inmobiliarias.

Al mismo tiempo, una encuesta de Ipsos sobre hábitos y actitudes hacia el Internet, demuestra que el $88 \%$ de los peruanos tiene conexión a internet desde su casa y el dispositivo mediante el cual se conectan es el celular o Smartphone con un 64\%. (2018).

En adición, el consumo de redes sociales que demuestra el estudio de LuJhon sobre Estadísticas del consumo Digital- Perú 2019 dicta que, en cuanto a medios digitales, los usuarios de Facebook e Instagram son quienes más interactúan con la red social y reciben publicidad. "24 millones de usuarios activos es la cantidad total que ven publicidad en Facebook y 5.2 millones de usuarios activos es la cantidad total que ven publicidad en Instagram.” (Lujhon, 2019) 
Por consecuencia, se sugiere utilizar las redes como Facebook e Instagram dentro de una campaña publicitaria, muy aparte de utilizar medios offline (que en el caso de la venta del Condominio, se utilizaran tanto medios off como online).

Los peruanos de 25-34 años pasan igual de tiempo en redes sociales que los de 18-24. Una campaña mixta en redes sociales ayudará a cubrir ambos públicos en tu estrategia de Publicidad digital. (Lujhon, 2019)

\section{Hallazgos claves}

\subsection{De la Marca}

La Inmobiliaria “Q'umir House" es una agencia inmobiliaria aliada a programas de ayuda social que ofrece alternativas alcanzables a través de fondos hipotecarios (como el nuevo Crédito Mi Vivienda) para que todas las personas puedan tener la oportunidad de conseguir el sueño de "la casa o depa propio". Nosotros somos una inmobiliaria que se encarga de promocionar edificios, condominios, casas y proyectos en general, que posean características amigables con el medio ambiente, con nuestra sociedad y que brinden oportunidades para todos (por ello el color verde y el nombre "Q'umir", palabra proveniente del Quechua que significa "Verde": orientado al propósito eco-friendly y el color celeste orientado a beneficiar la sociedad, y la palabra "house", del inglés, que significa hogar y completa la idea de una vivienda "verde". Asimismo, Q'umir House se posiciona como una alternativa diferente a las inmobiliarias tradicionales, ya que nos aseguramos de generar una estrategia de Marketing Digital orientada a resultados como ventas o alquileres en un corto plazo de tiempo. 

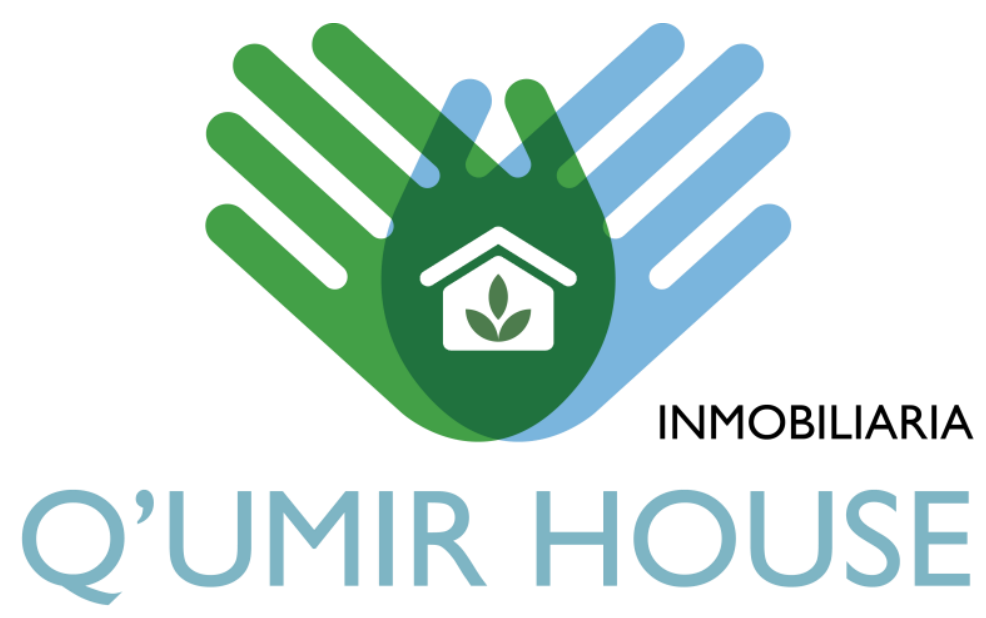

Ilustración 1: Logo Inmobiliaria Q'umir House. Fuente: Propia.

Nuestra inmobiliaria Q'umir House plantea 3 etapas en cuanto a la promoción de proyectos que tengamos con el fin de conseguir objetivos lo más rápido posible.

- Etapa 1:

En esta primera etapa se atrae a los interesados a través de un plan de marketing global con la ayuda del análisis de un experto inmobiliario.

- Etapa 2:

Se verifican las visitas, se controlan, se agendan y vienen las ofertas y propuesta de fondos hipotecarios a elección del posible comprador.

- Etapa 3:

La operación se cierra, se brindan los trámites legales la documentación y el contrato. Además, los compradores son asesorados y se les acompaña a una firma exitosa

Nuestra inmobiliaria decidió llevar a cabo la venta de este gran proyecto debido a su razón de ser. El condominio se creó con la finalidad de albergar más de 6 mil deportistas de toda América para la realización de los Juegos Panamericanos y Parapanamericanos. Este emblemático evento deportivo nos emocionó y se posicionó en nuestra mente como la alta capacidad del peruano para ofrecer un evento de calidad con instalaciones de alto estándar y dejar huella en los países invitados sobre nuestra perseverancia y garra para 
cumplir nuestros objetivos y promesas. La razón por la cual, el condominio Villa del Atleta se convirtió en nuestro proyecto, es porque nosotros buscamos vender un sueño, una posibilidad de vivir en un paraíso dedicado a fomentar el bienestar y la salud, que es inclusivo con las personas que poseen alguna discapacidad, que sus departamentos poseen características eco-amigables en su diseño y construcción: como tener ahorro energético con sistemas de iluminación de bajo consumo y también ahorro de agua.

La Villa del Atleta les brindará espacios en los cuales sus residentes podrán reunirse con sus seres queridos. En ella se podrán sentir seguros, tener comodidad y tranquilidad, interactuar con su familia dentro de sus instalaciones sin temor alguno porque se encuentran dentro de su hogar y sobretodo, los transportará a revivir los triunfos de nuestros campeones cada día porque decidieron vivir en uno de estos 1096 departamentos junto a nuestros medallistas de oro.

\subsection{Del Mercado:}

El sector inmobiliario en el Perú es un mercado altamente demandado en el cual, la compra-venta de bienes inmuebles como lo son los departamentos, se pueden adquirir mediante múltiples plataformas en las cuales puedes ser acreedor de una nueva vivienda, tanto mediante compra o alquiler.

Entre estas plataformas destacan las páginas: adondevivir.com, urbania.pe, casas.trovit.com.pe, casas.mitula.pe, infocasas.com.pe, Olx, Mercado libre y hasta en Facebook. 


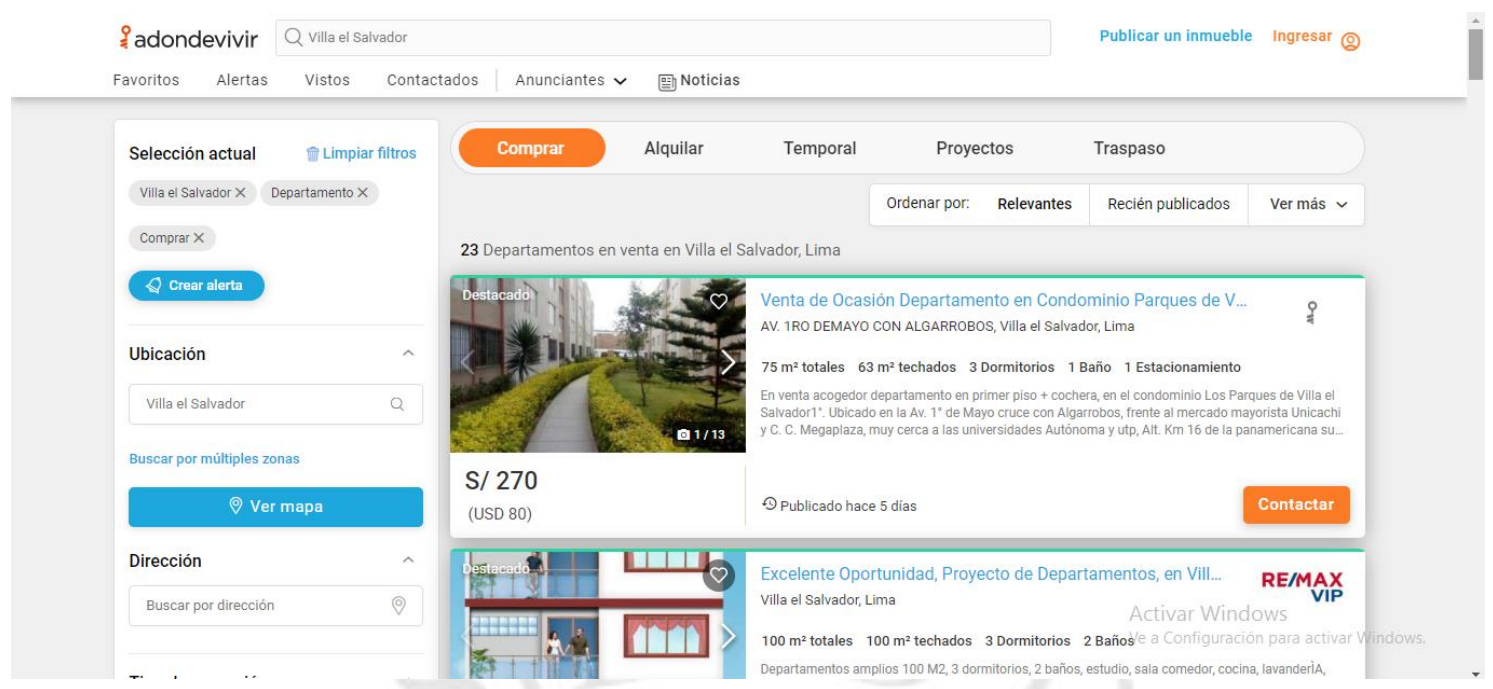

Ilustración 2: Web A donde Vivir. Fuente: adondevivir.com.pe

\section{trovit venta v departamento villa salvador}

Trovit > Departamento > Región de Lima > Provincia de Lima > Departamento villa salvador

Departamento en venta en Villa El Salvador
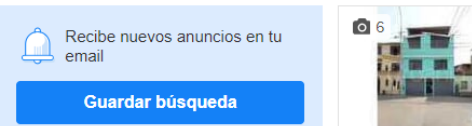

Venta de Departamento en Villa El Salvador

Villa El Salvador, Provincia de Lima, Región de Lima

Vendo departamento en villa el salvador en el $s$,
sala-comedor, dos baños, cocina, dos dormitorios.

U Urbania

Ordenar por
Relevancia

Ubicación

Ubicación
Jesús María 1.485

Las Olivos 880

Magdalena del Mar 1.2

San Bartolo 243

San Borja 4.220

San Juan de Lurigancho 3 th

San Juan de Miraflores 298

Santiago de Surco 13.1

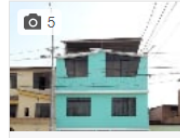

Departamento $122 \mathrm{~m}^{2}$ de 4 habitaciones con Antigüedad, Lima...

Villa El Salvador, Provincia de Lima, Región de Lima

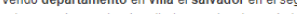

P PATRerali

이 6

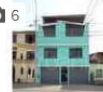

Venta de Departamento en Villa El Salvador

Villa El Salvador, Provincia de Lima, Región de Lima

sala-comedrar BLOQUEAR ACEPTAR

Ilustración 3: Web Trovit. Fuente: casas.trovit.com.pe

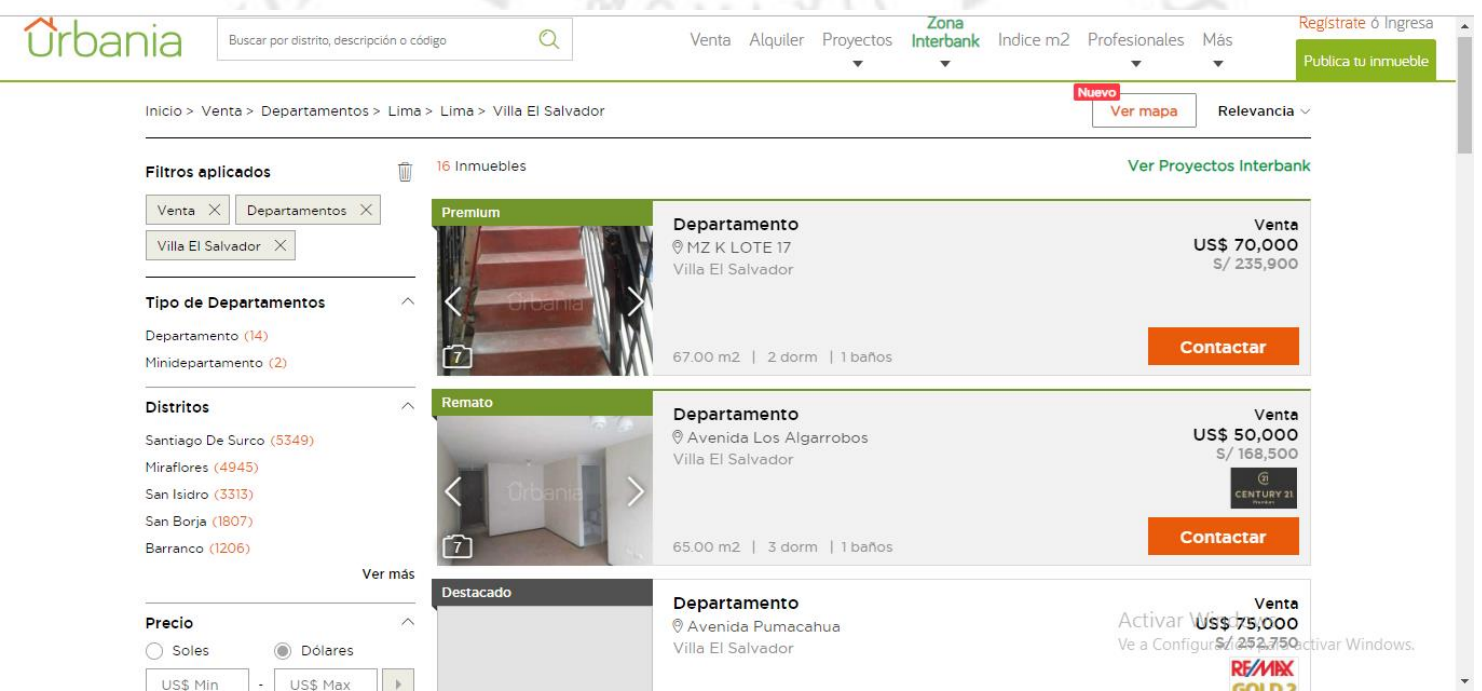

Ilustración 4: Web Urbania. Fuente: urbania.pe 


\begin{tabular}{l} 
INFOCASAS VENTA ALQUII \\
\hline Hit Búsqueda Avanzada \\
\hline Tipo de Operación \\
$\odot$ Venta \\
Alquiler \\
Alquiler Temporal \\
Tipo de Propiedad \\
$\square$ Casas \\
$\square$ Departamentos \\
$\odot$ Más opciones \\
Tu Búsqueda \\
Lima $\mathrm{x}$ Villa El Salvador $\mathrm{x}$ \\
Barrios más demandados \\
$\odot$ Nazca \\
$\odot$ Rimac
\end{tabular}

Venta de Departamentos en Villa El Salvador

Mostrando 1 - 11 de 11 resultados

Estás en: InfoCasas > Venta > Departamentos > Lima > Vilia El Salvador

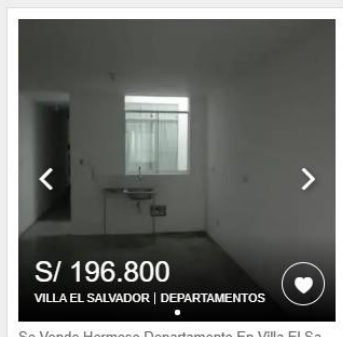

Hermoso Departamento En Villa El Sa

3 Dormitorios Baños $160 \mathrm{~m}^{2}$

Consuliar

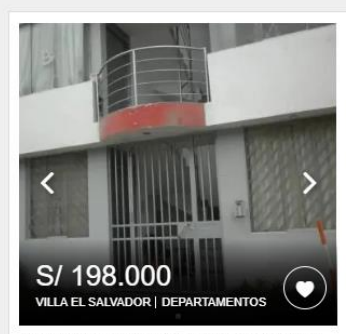

Vendo Acogedor Departamento Villa El Salvader

3 Dormitorios | Baños $\mid 60 \mathrm{~m}^{2}$

Consultar

\begin{tabular}{c|c|c} 
Contacto Publicar Iniciar Sesión & Registrarse
\end{tabular}

Mapa Popularidad

Ilustración 5: Info Casas. casas.mitula.pe

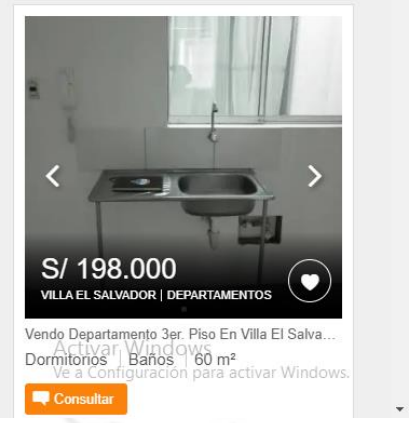

\section{ax) \\ departamento-en-villa-el-salvador \\ Q

Categorias $\vee \mid$ Ingresar $\mid$ Reglstrarse $\mid$ Ayuda $\quad$ (O) Vender

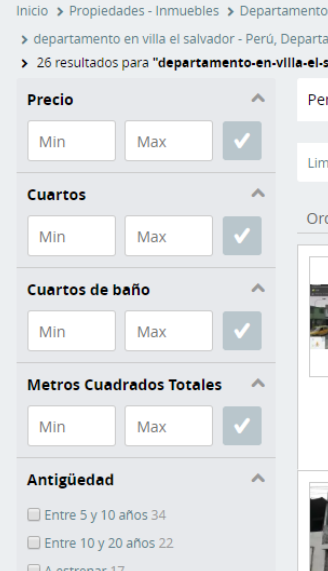

\section{Perú}

Lima 132

Ica 1

Ordenar por: Relevancia -

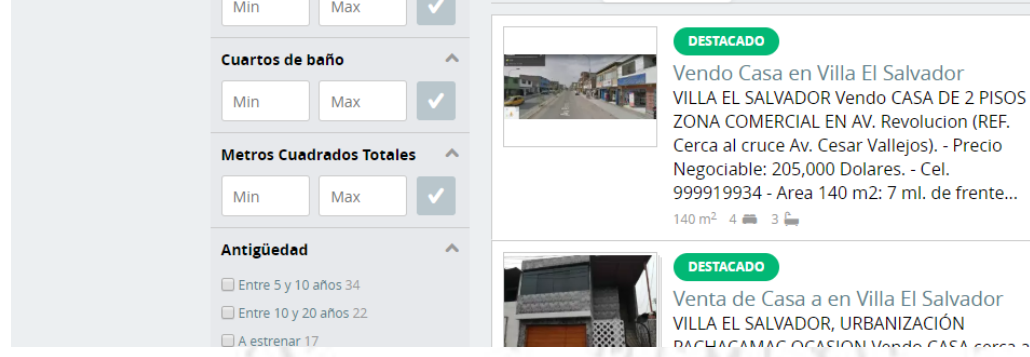

Ilustración 6: OLX. Fuente: olx.com.pe

S205.000USD

Departamento en villa el salvador Peru- 


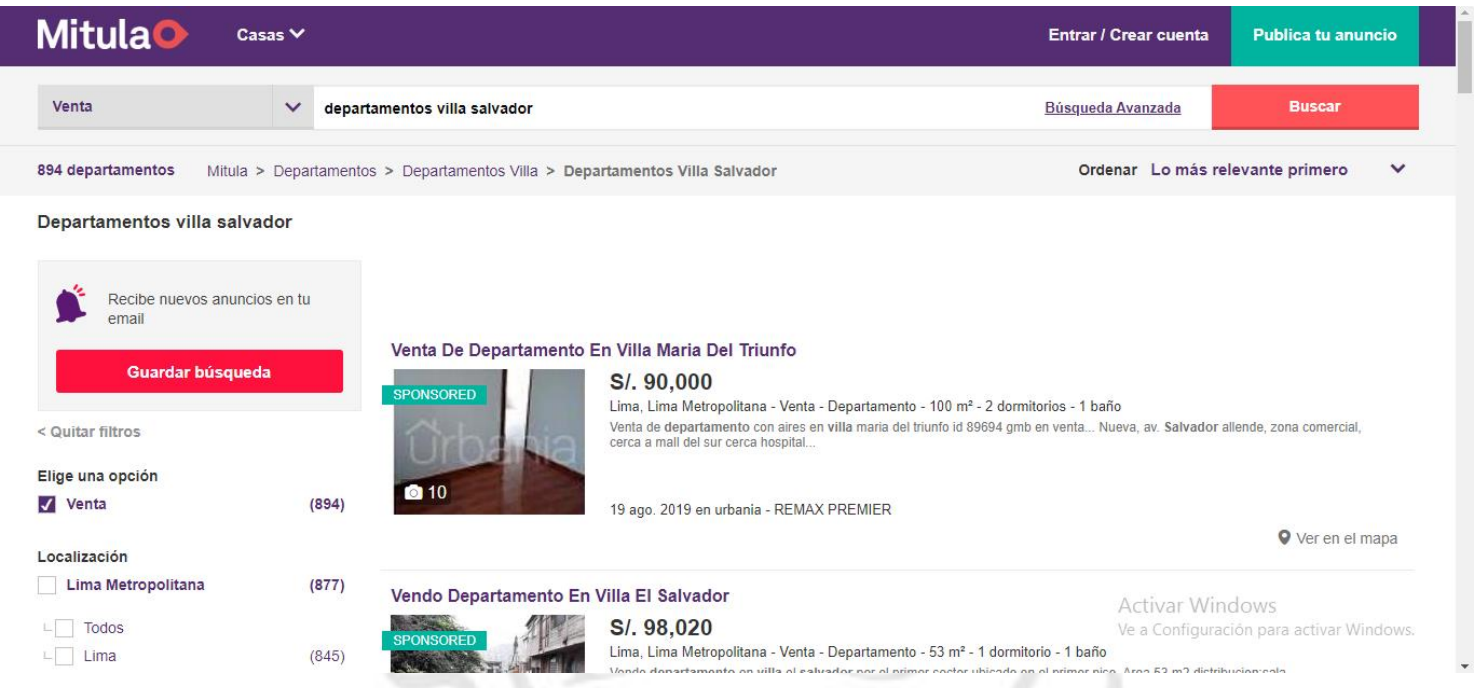

Ilustración 7: Mitula. Fuente: casas.mitula.pe

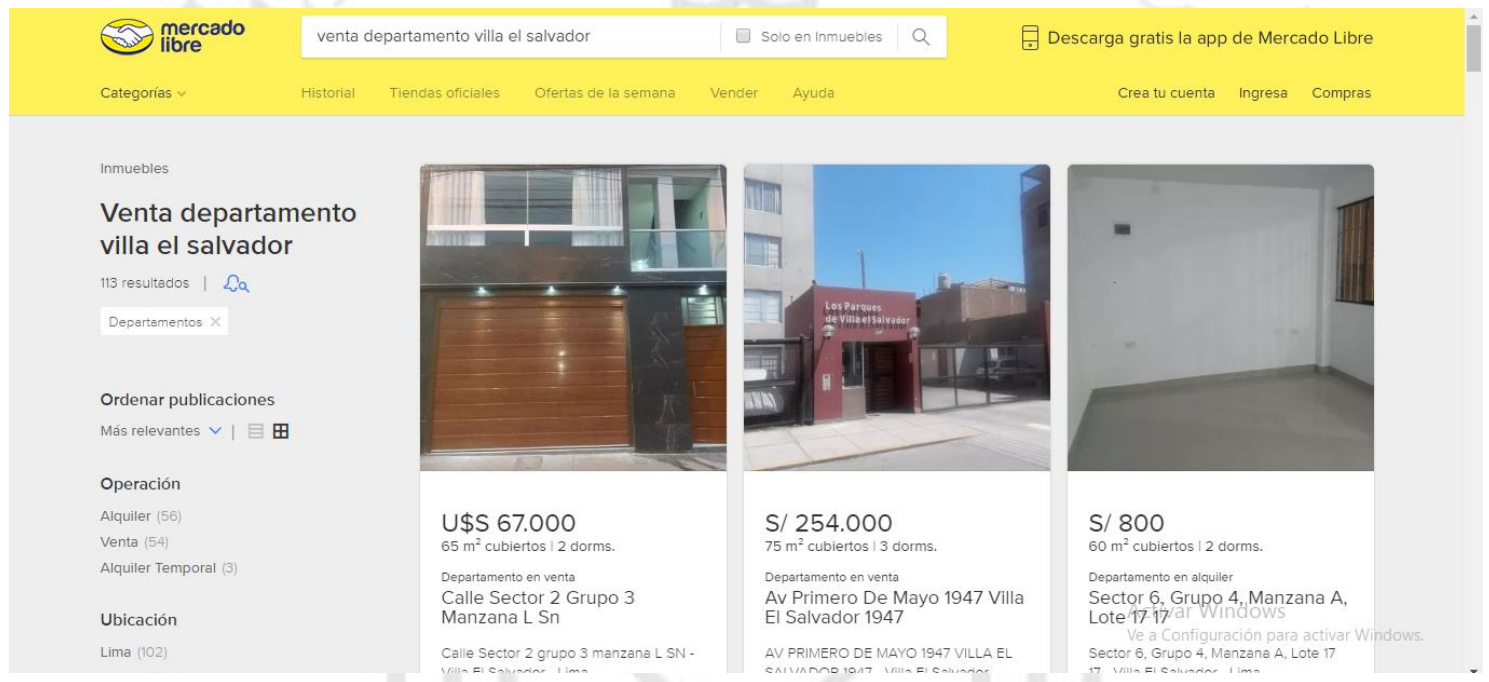

Ilustración 8: Mercado Libre Fuente: mercadolibre.com.pe

En estos sitios web puedes buscar una vivienda con las características que desees encontrar (distrito, $\mathrm{n}^{\circ}$ de cuartos, $\mathrm{n}^{\circ}$ de baños, zonas de esparcimiento, cochera, rango de precio, etc.), así como publicarla para su venta o alquiler. Solo en Olx y mercado libre podrás además buscar todo tipo de bienes tanto muebles como inmuebles.

A diferencia de todos, la búsqueda de departamentos a través de Facebook no se logra mediante el buscador, sino en páginas o grupos llamados "Compra y venta de Departamentos Villa El Salvador" o "Vecinos Villa El Salvador" o simplemente publicaciones de personas naturales que buscan vender o alquilar su departamento entre su círculo de amigos o conocidos. 
Siguiendo con el análisis del mercado, dentro de estas páginas se aprecia cómo una persona natural publica un anuncio, al igual que también lo hacen las inmobiliarias.

Si nos enfocamos en el caso de la venta del Condominio Villa del Atleta, lo más certero es que una inmobiliaria con agencia in-house se dedique al objetivo porque su negocio y objetivo es generar ventas.

En este caso, nosotros formamos parte del área de comunicaciones de la inmobiliaria Eco-Wasi y nos encargaremos de la producción de artes publicitarios para medios BTL, $\mathrm{OOH}$, prensa y digital de los cuales se explicará en el punto de la campaña.

\subsection{De la competencia:}

Para analizar la competencia debemos tener en cuenta nuestras características del Condominio para poder listar nuestros competidores. En cuanto a la competencia directa, buscamos entonces condominios dentro del distrito de Villa el Salvador que tengan 3 dormitorios y demás similitudes en cuanto a su infraestructura.

\subsubsection{Competencia Directa}

Dentro de la Competencia que existe en cuanto a la venta de condominios, tenemos un competidor que califica como directo.

Los parques de Villa el Salvador I y II, son condominios ubicados en la Avenida de Los Algarrobos en el Distrito de Villa El Salvador. Comprende 14 edificios de 5 pisos cada uno y cada piso cuenta con 4 departamentos. Posee una sala de usos múltiples, un local comercial, una terraza y juegos para niños.

Los parques de Villa El Salvador II se publicitan mediante una landing page propuesta por la inmobiliaria que las vende: "Viva GyM" donde describe sus especificaciones, otorga fotos y la facilidad de ponerse en contacto. 


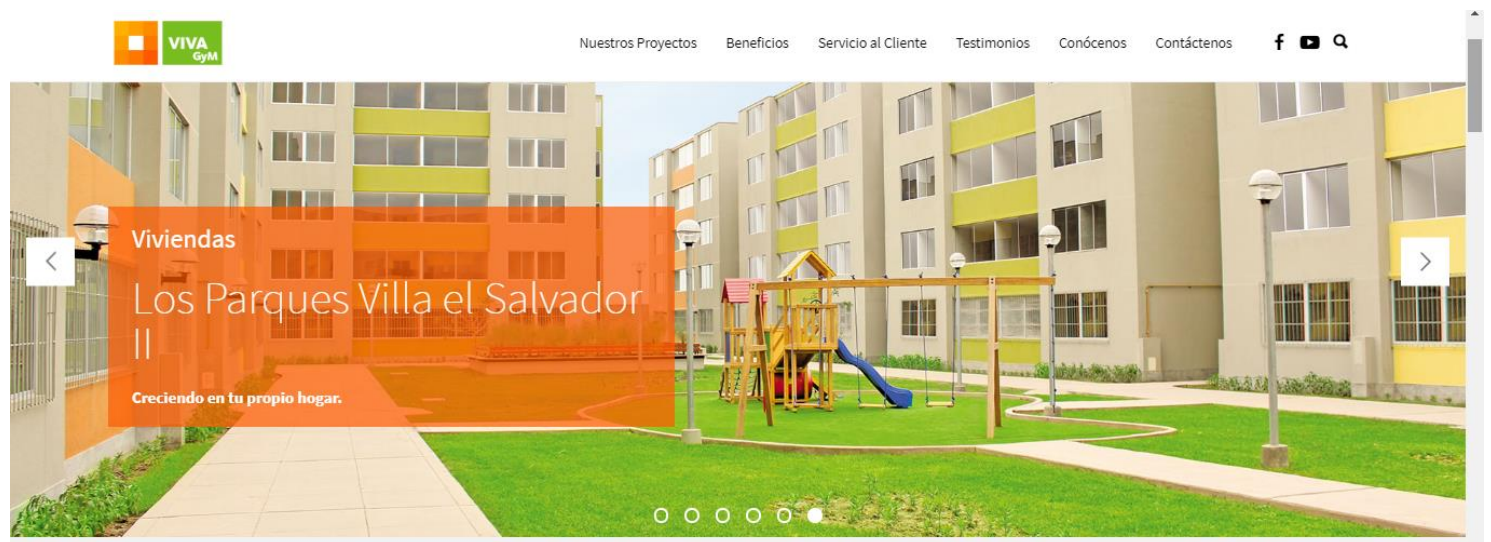

Los Parques de Villa El Salvador II

Ilustración 9: Los parques de Villa El Salvador. Fuente: Viva GyM

\subsubsection{Competencia Indirecta}

Dentro de la competencia Indirecta se encuentran condominios o departamentos independientes en la Zona Lima Sur.
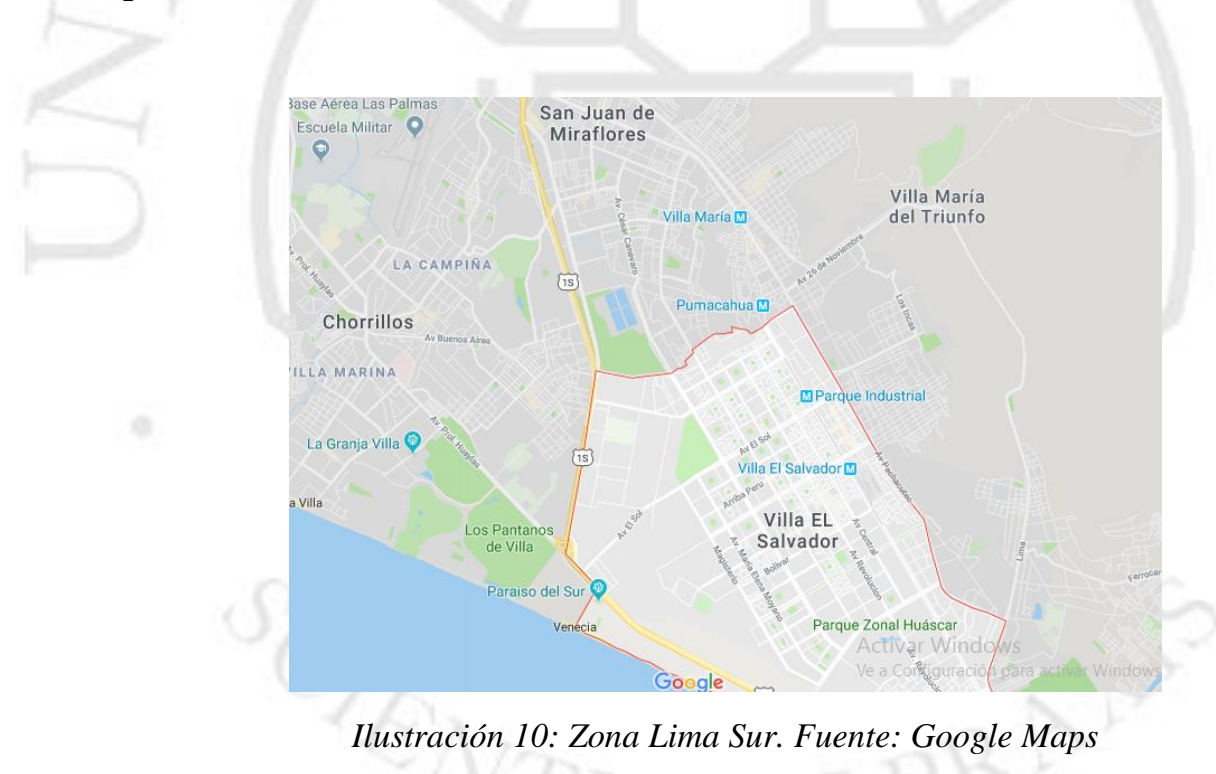

Para ser categorizados como competencia indirecta no deberán ser condominios vendidos a través de inmobiliaria. Por lo tanto en el cuadro de Benchmark que se realizó, colocamos Departamentos independientes vendidos tanto por personas naturales como inmobiliarias y también un departamento incluido en condominio pero vendido por una persona natural. En el siguiente link podrán apreciar el cuadro con la competencia.

\section{Benchmark de competencia:}

https://drive.google.com/open?id=1-v5XDXDEmUoCslMgQ6rHlBaOjRzrmNEN 


\section{Público Objetivo}

El condominio Villa del Atleta está ubicado en el distrito de Villa el Salvador y por lo tanto nuestro público objetivo está delimitado entre jóvenes y adultos de 25-55 años del NSE C y D, que tengan el sueño de conseguir un departamento propio.

Con la finalidad de conocer al público con el que debemos conectar es necesario mencionar las características más relevantes de acuerdo a estudios y encuestas realizadas. Al terminar esta recapitulación se realizará un breve resumen, el cual permitirá tener consolidado ciertos puntos estratégicos en los que podrá llevarse a cabo la campaña de marketing integral.

En primer lugar, para ayudar a delimitar nuestro público objetivo, hemos tomado de referencia un estudio de Ipsos del año 2017, denominado "Perfiles Zonales: Lima Metropolitana" basado en Lima Sur, donde se ubica nuestro distrito de interés. Estos son los datos que hemos podido resaltar:

\subsection{Perfil económico y demográfico:}

- Lima Sur comprende el 32.5\% del nivel socioeconómico C y el 35.2\% del nivel socioeconómico D.

- El ingreso promedio mensual del hogar es aproximadamente 3295 soles de los cuales el $21 \%$ va destinado hacia el alquiler de una vivienda y el $3 \%$ al mantenimiento de vivienda.

\subsection{Perfil Social de Interés (ama de casa y jefe del hogar):}

- $44 \%$ de los hogares son nucleares con hijos, es decir pareja con hijos y sin otros familiares y el $26 \%$ de los hogares están en la etapa de consolidación, es decir que tienen hijos menores de edad.

- Para el perfil de jefe del hogar el $64 \%$ lo tienen los hombres y el 36\% las mujeres. 
- $\quad$ El 33\% de los jefes de hogar tiene entre 40-54 años y un 22\% de 25-39.

- La mayoría se encuentra casado(32\%) o es conviviente(29\%).

- El 74 \% de ellos trabaja así que su situación económica es sustentable como para conseguir una vivienda.

- El promedio de edad que tienen son los 39 años dentro de Lima Sur.

- En cuanto a las amas de casa, $45 \%$ son convivientes y $31 \%$ son casadas.

- 5 de cada 10 amas de casa se dedica exclusivamente al cuidado del hogar y cuatro de ellas son amas de casa y al mismo tiempo tienen un trabajo eventualmente.

- En su tiempo libre las amas de casa de Lima Sur prefieren pasar el tiempo con sus hijos $(21 \%)$ y ver televisión(20\%).

\subsection{Perfil del adulto joven (21-35 años):}

- $53 \%$ son mujeres y pertenecen al nivel socioeconómico C (39\%) y el $33 \%$ al nivel socioeconómico D.

- 7 de cada 10 tienen pareja y el $67 \%$ son padres.

- Un $27 \%$ de ellos ya se independizó y ha dejado de vivir con sus padres.

- Asimismo un 53\% se encuentra trabajando.

\subsection{Perfil del internauta de Lima Sur}

- Cuatro de cada 10 internautas se conecta siete o más veces por semana a Internet y acceden al Internet desde una computadora o laptop (57\%) y a través del smartphone (34\%).

- El 57 \% tiene conexión a Internet en el hogar.

- $\quad$ El $76 \%$ pertenece a alguna red social y la mayoría tienen Facebook. 


\subsection{Perfil del usuario de medios de Lima Sur}

- Escucha el radio seis días a la semana.

- Los géneros que más escuchan son baladas (61\%), salsa y merengue con un $38 \%$ y rock español con un $34 \%$.

- Las emisoras más escuchadas son Studio 92 con un 30 \%; y moda y felicidad con un $20 \%$.

- Leen diarios cuatro días a la semana entre los que más leen está Trome $84 \%$, ojo $37 \%$ y el comercio $20 \%$

Reforzando el Perfil del Usuario de Lima Sur, en cuanto al consumo de radio, según un estudio de IPSOS del año 2017 llamado "Instituciones en las que más confían los peruanos" se demuestra que la radio genera mayor credibilidad y confianza que la Televisión por lo cual podemos tomarlo como uno de nuestros medios tradicionales al momento de plantear la estrategia de comunicación.

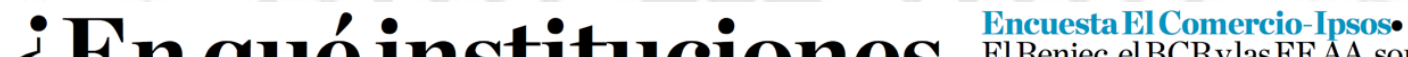 ¿En qué instituciones confían los peruanos? desconfianza por la ciudadanía.}

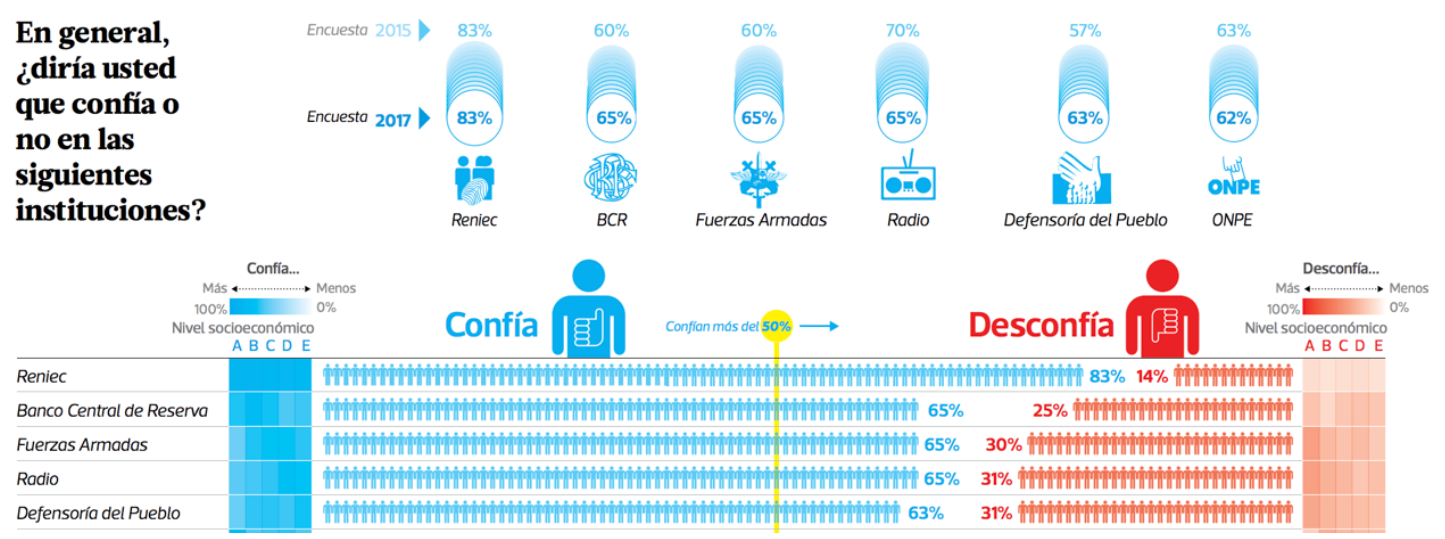

Fuente: IPSOS. Elaboración: IPSOS 2017

Asimismo, un estudio del CPI(2018) sobre la Audiencia Radial Nacional, afirma: 
- La radios el medio masivo en el que los sectores C y D pasan mayor parte de horas a la semana escuchándolo.

- Genera efectividad: logra un alto retorno por el impacto a millones de oyentes diarios.

- Genera recordación de marca y aporta un 30\% de aumento de la recordación de la marca, lo cual beneficia proyectos que posean objetivos tanto a corto como largo plazo.

Por otro lado, reforzando el perfil del adulto joven peruano, un estudio de Ipsos del 2018 demuestra que el $79 \%$ de los 2.7 millones de adultos jóvenes en Lima, ahorra y lo hace para comprar algún inmueble o para invertir en negocios.

$84 \%$ se encuentra trabajando y $85 \%$ es digital, por lo cual, en cuanto al uso de dispositivos: $61 \%$ tiene Smartphone y el $15 \%$ compra por internet.

\subsection{Encuestas a público objetivo}

Para terminar de segmentar y entender a nuestro target, realizamos una encuesta a 16 personas: 8 hombres y 8 mujeres. Entre los 25 años y los 55 años de edad. Si bien no es una cantidad acorde al volumen de la población de Villa El Salvador, ayudará a estimar en cuanto a porcentajes, las preferencias y el know-how del público. A continuación, se desglosará cada pregunta y lo que se puede estimar de sus respuestas.

\section{SEXO}

16 responses

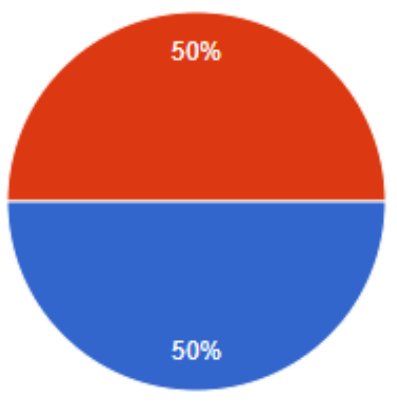


Decidimos equilibrar el número de hombres y mujeres con la finalidad de no presentar un interés adicional por el sexo de la persona dentro de nuestro target.

\section{EDAD}

\section{6 responses}

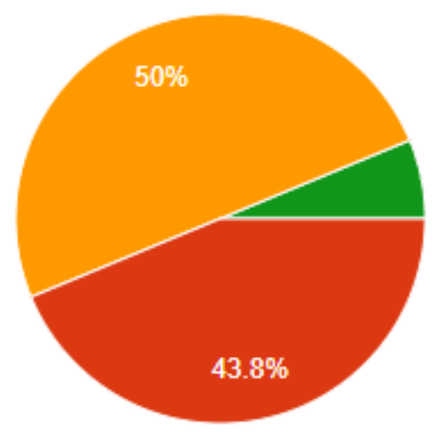

Dentro de esas 16 personas: 8 de ellas tienen entre 35-45, 7 tienen $25-35$ y solo 1 está entre el rango de 45-55 años de edad.

Una de las preguntas que debíamos resaltar era si los encuestados había visualizado o estado al tanto de los Juegos Lima 2019. Se entiende como un factor que iba a permitir contribuir a una conclusión con respecto del condominio.

¿Seguiste los Juegos Panamericanos y Parapanamericanos Lima 2019?
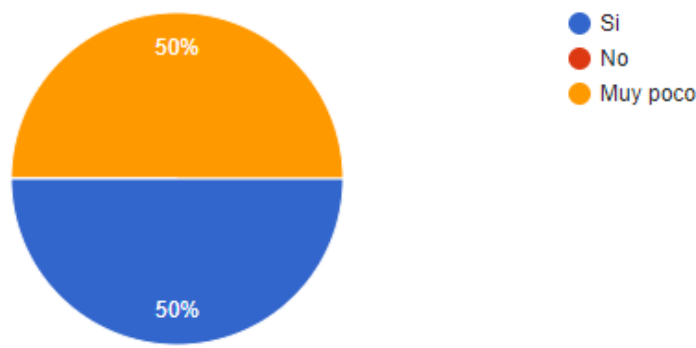
Entendemos que si la mayoría no los siguió completamente, al menos estuvieron enterados de la coyuntura.
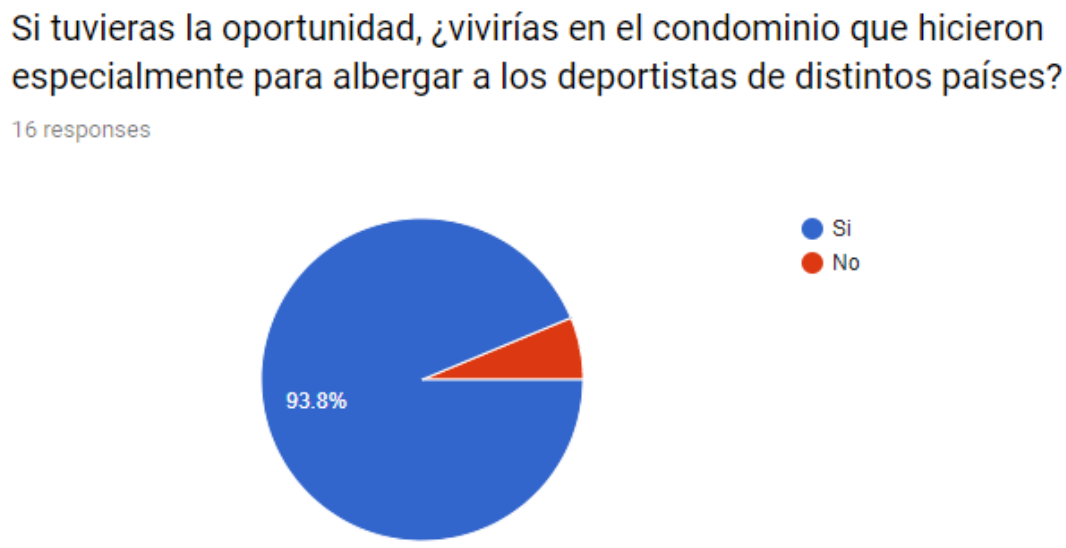

Figura 4: Seguimiento de los Juegos Lima 2019. Fuente: Propia.

Solo 1 de nuestros encuestados colocó que no viviría en el condominio porque tiene una vivienda donde ya se siente a gusto.

Seguidamente, les dijimos que justificaran por qué sí y por qué no y estos fueron los resultados:

- Porque me parece interesante vivir en un lugar donde varios deportistas estuvieron

- Porque siento que es seguro

- Parece espacioso y cómodo

- Parece seguro y espacioso

- Porque sería cómodo

- Son bonitos y cómodos

- Porque estoy cómoda donde estoy(quien dijo no)

- Porque tiene reconocimento el lugar

- Porque nos informamos que es inclusiva y mi hermano tiene discapacidad

- Es un ambiente positivo y seguro

- Siento que habría una bonita comunidad 
- Parece un lugar moderno y cómodo

- Moderno y cómodo

- Pareciera moderno y seguro

- Moderno y seguro

Por lo tanto, tenemos en cuenta que la visión que ellos proyectan hacia el Condominio Villa del Atleta es un espacio cómodo, espacioso, inclusivo, seguro y apto para adecuarse a un estilo de vida saludable.

Seguidamente les preguntamos el tipo de vivienda donde ellos se encuentran, la mayoría tiene vivienda alquilada y otra gran parte vive con sus familiares todavía.

¿En qué tipo de vivienda vives?

16 responses

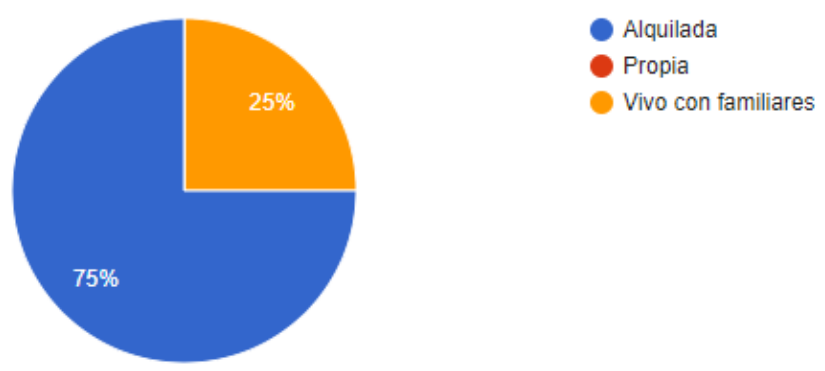

Figura 5: Tipo de vivienda que tienen. Fuente: Propia.

Sin embargo, todos ellos expresan que les gustaría tener una vivienda propia porque es una forma de sentirse más independientes. 
En caso tu vivienda no sea propia, ¿te gustaría tener una?

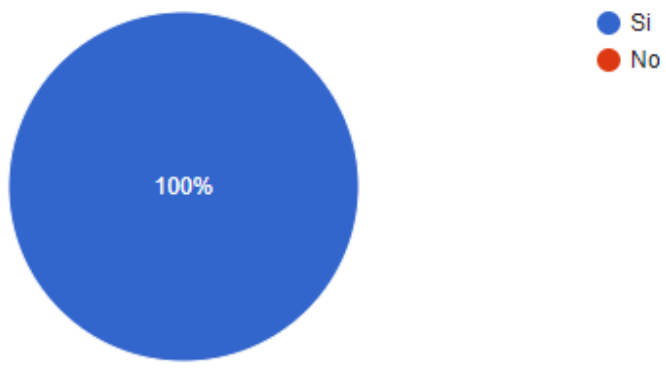

Figura 6: ¿Les gustaría tener vivienda propia? Fuente: Propia.

\section{¿Cuántos cuartos te gustaría que tenga?}

\section{6 responses}

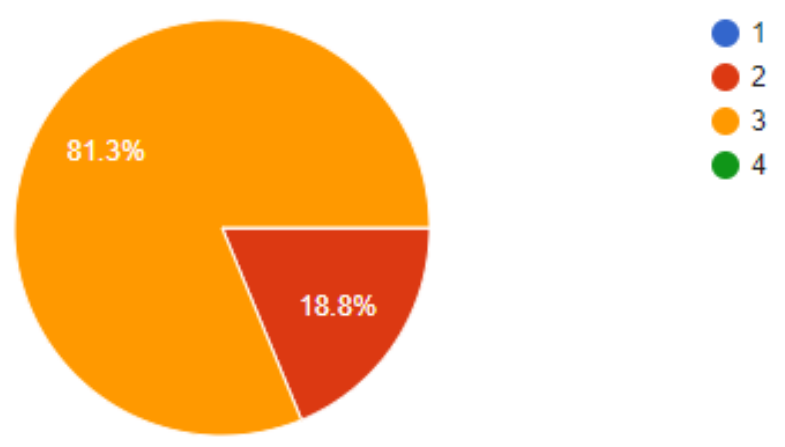

Figura 7: Número de cuartos que le gustaría tener. Fuente: Propia.

Les preguntamos también cuántos cuartos les gustaría tener y el mayor estimado indica 3 dormitorios, que es justo lo que ofrecemos.

Asimismo, queríamos que se explayen en cuanto a lo que ellos valoran cuando piensan tener una nueva vivienda. Estas fueron sus respuestas: 
- Que me haga sentir segura

- Espacio, seguridad, vecinos

- Propia, comodidad, espacio

- $\quad$ Bajo precio, comodidad, seguridad

- Espacio

- Seguridad

- Espacio, comodidad, seguridad

- Seguridad, comodidad, espacio

- Zonas cercanas para ejercitar y convivir

- Espacio, que te haga sentir seguro y en familia

- Seguridad y comodidad

- Buen ambiente, seguridad, precio

- Comidas, y precio

- Espacioso y precio

- Que esté en un lugar seguro y que sea cómodo vivir ahí

- Precio y comodidad

¿Cuáles consideras valores agregados que pueda tener una vivienda a tu disposición? (PUEDEN MARCAR VARIAS OPCIONES)

16 responses

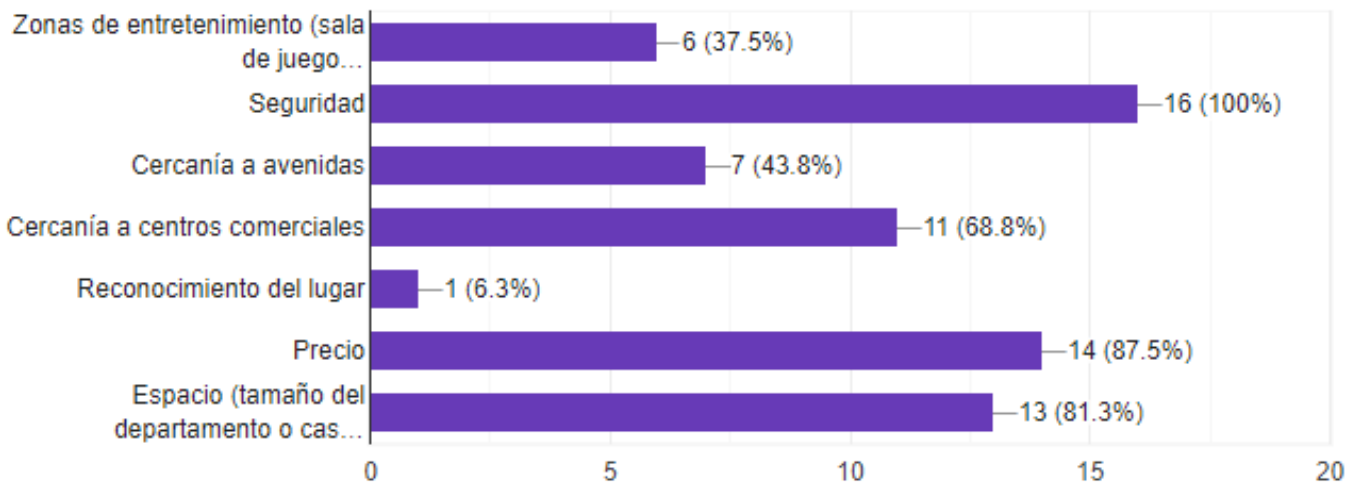

Figura 8: Valores agregados para tu vivienda. Fuente: Propia.

A manera de resumen, colocamos a su disposición marcar los valores agregados que les importa al plantearse vivir en una nueva vivienda. De acuerdo a los resultados, sentirse en un lugar seguro es lo más importante, seguido de un buen precio y espacio. Asimismo, 
6 personas de los 16 valoran que los departamentos tengan zonas de esparcimiento en donde puedan convivir entre ellos con sus amigos y familia.

¿Conoces el Nuevo Crédito Mi Vivienda?

16 responses
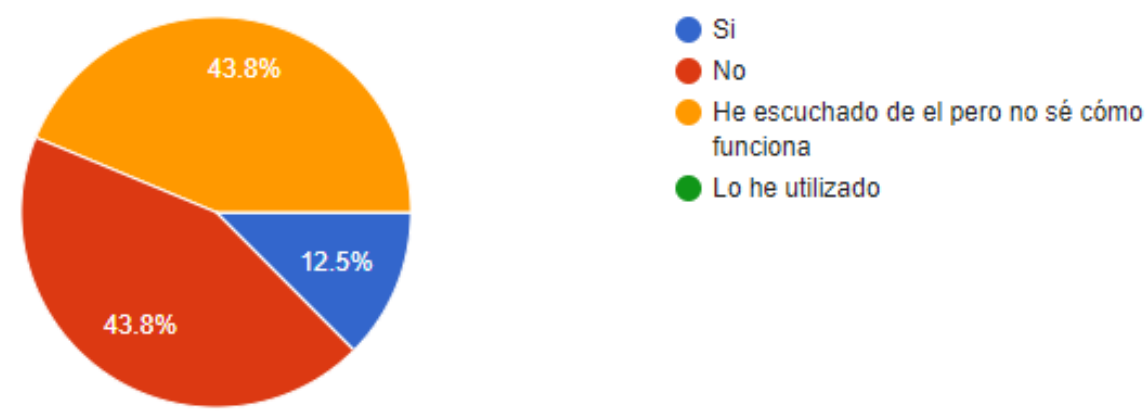

Figura 9: Conocimiento del Nuevo Crédito Mi Vivienda. Fuente: Propia.

Como es de conocimiento general, el Condominio Villa del Atleta podrá adquirirse mediante el Nuevo Crédito Mi Vivienda, este fondo hipotecario permitirá que nuestro público pueda sustentar su vivienda en cómodas cuotas mensuales y facilitar todo el proceso engorroso que puede conllevar la compra de un inmueble.

Con el Nuevo Crédito Mi Vivienda podrías financiar hasta el $90 \%$ del precio tu casa o departamento. ¿Te interesaría postular?

16 responses

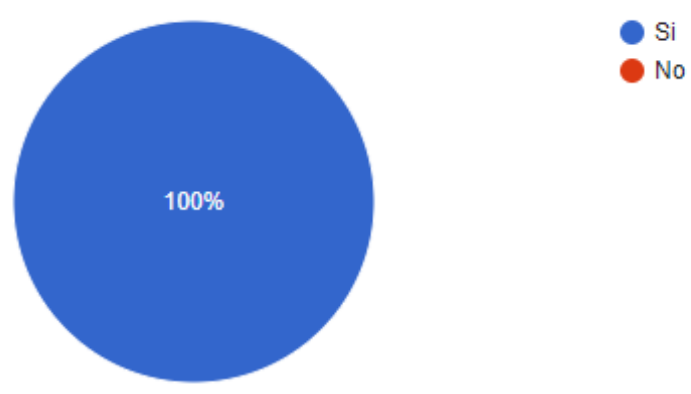

Figura 10: Interesado en postular al Nuevo Crédito Mi Vivienda. Fuente: Propia. 
Por lo tanto, de acuerdo a estas respuestas podemos ver que a todos los interesados les gustaría participar del Nuevo Crédito Mi Vivienda por las facilidades que brinda y sus descuentos adicionales añadidos al costo real: Bono del Buen Pagador y Mi Vivienda Verde. Esto permitiría resolver el tema del "precio" cuando se habla de encontrar un departamento "a su presupuesto". Debido a que, los interesados podrán dividirse el costo del departamento en unos 5 a 20 años en cuotas factibles a su sueldo.

Quiere decir entonces, que al plantear nuestra estrategia de marketing y comunicación habrá que informar la facilidad a través del fondo hipotecario, el estilo de vida que podrán llevar dentro del complejo habitacional y la oportunidad de sentirse en familia, cómodos entre sí, poder fomentar un estilo de vida saludable y por último, sentirse seguros.

\section{La Marca}

\subsection{Posicionamiento del Condominio Villa del Atleta}

Para los jóvenes adultos que buscan tener la oportunidad de una vivienda propia acorde a su estilo de vida, el condominio Villa del Atleta tiene la energía positiva que busca transmitir, la seguridad, la integración y unión que aporta en su entorno habitacional.

\subsection{Promesa}

Otorgar el sueño del departamento propio adecuado a tu estilo de vida en el que podrás integrarte, sentirte incluido cada día y pasar momentos en familia.

\subsection{Ventaja Diferencial}

Ofrecer un departamento propio que se acomode a tu estilo de vida saludable, positivo para ti y tu familia, donde pasarán momentos de confraternidad y que todo aquel que viva ahí se sentirá a gusto, seguro e incluido dentro de la familia Villa del Atleta. 


\subsection{Reason Why}

- El Condominio VILLA DEL ATLETA es un complejo habitacional adecuado a un estilo de vida saludable, donde reina la inclusión, la confraternidad y el sentirse seguro, la integración de las familias.

- El estilo de vida saludable predomina desde que escuchamos el nombre del condominio. Automáticamente lo enlazamos también con los Juegos Lima 2019 y nos brinda las facilidades de poder llevar una vida saludable con su pista para correr, la pista para bicicletas de $1 \mathrm{~km}$ de distancia y el gimnasio que está incluido en este condominio de 7 torres.

- La confraternidad se hace presente con los salones de juego, y demás zonas edificadas para interactuar entre familias, poder convivir y pasar tiempo con los que más quieres.

- La inclusión se transmite porque brinda apoyo y facilidades a las personas con discapacidad para que se sientan integradas y parte de una sociedad que vela por ellas.

- Nuevo Crédito Mi Vivienda te da la facilidad de poder financiar tu departamento y poder costearlo en cómodas cuotas mensuales durante un periodo de 5-20 años con la finalidad de hacer una realidad el sueño de tu vivienda propia.

- La inmobiliaria Q’umir House se encargará, a través de una estrategia de Marketing que abarca medios offline como medios online, de lograr la venta total de los departamentos que consignan el Condominio Villa de Atleta.

\subsection{Misión}

Somos el refugio de nuestros deportistas de los Juegos Lima 2019 y luchamos por darle la misma oportunidad de sentirse en casa a los vecinos de Villa el Salvador.

\subsection{Visión}

Ser el dulce hogar de los aspirantes a una vida sostenible con dedicación, disciplina y responsabilidad día a día. 


\subsection{Tono:}

El tono de comunicación mediante el cual estaremos hablándole a nuestro potencial comprador será ameno, en primera persona y refrescante. El mismo hecho de tratar a los clientes con una tonalidad fresca y que te haga sentir jovial y entusiasta, conllevará una mejor empatía con el target y podrán sentir que el entorno del condominio es positivo. Ello supondrá obtener la confianza del público objetivo y que ellos se sientan cómodos en el espacio que ofrecen los departamentos de Condominio.

\subsection{Color}

Si bien la psicología del color es subjetiva de acuerdo a múltiples aspectos, para el planteamiento del logo del Condominio Villa del Atleta, se estimó utilizar como recurso 4 colores: el crema, el guinda, el verde y el negro.

En primer lugar, para el desarrollo del isotipo se utilizaron los colores crema y guinda. Los cuales, además de representar la tonalidad de los edificios y el color de una pista atlética, también por su parte, el color crema o beige de los edificios tiene su propio significado. Según la Diseñadora Gráfica y Web, Cameron Chapman (2010) color crema evoca la calidez del marrón y la frescura del blanco. Asimismo, ella ejemplifica que el color crema proporciona calma y a su misma vez elegancia que en teoría se busca destacar de una vivienda, que se vea elegante y al mismo tiempo moderno.

En segundo lugar, el color guinda de la pista atlética, viene a ser una fusión de los colores rojo y marrón.

Según el estudio de Belburo Studio (2018) sobre la psicología del color, la tonalidad marrón (obtenida del guinda), que se suele asociar a las viviendas, también representa la naturaleza y la tierra, por lo tanto estos dos factores refuerzan la idea de que el condominio sea amigable con el medio ambiente. 


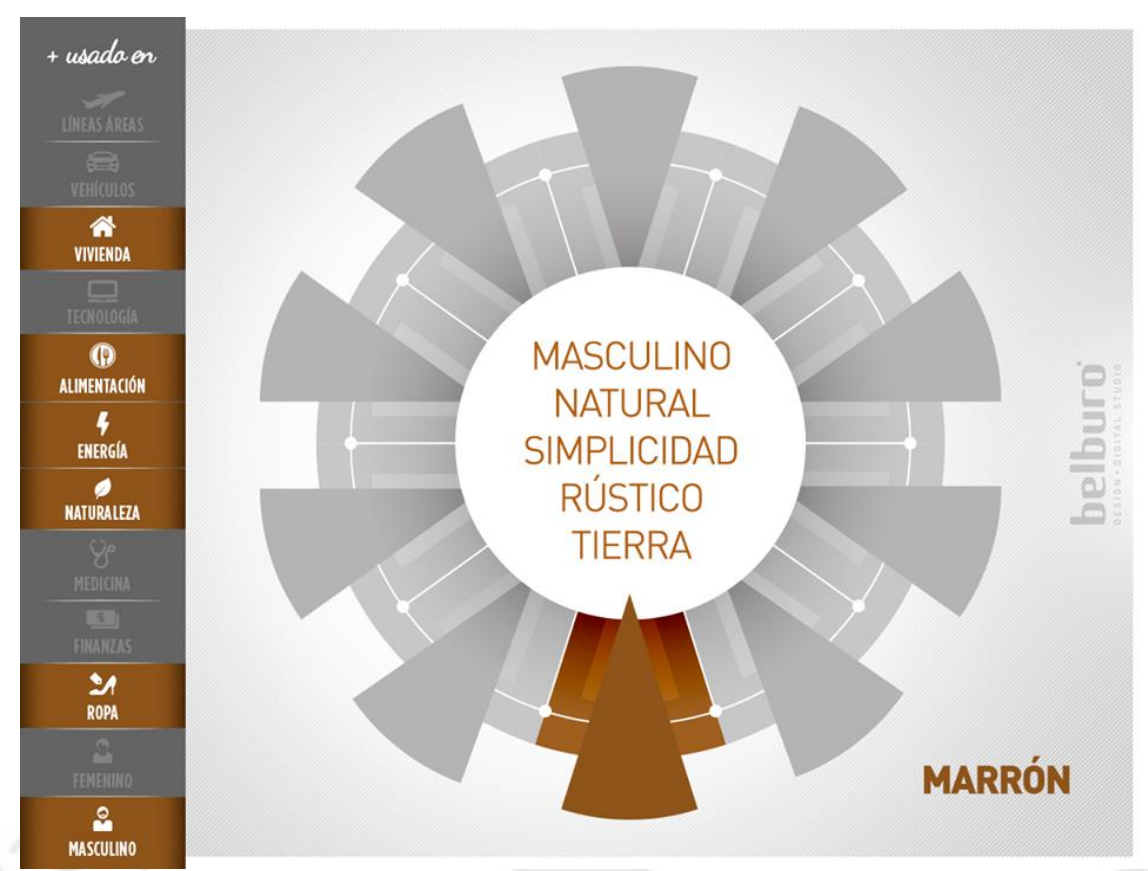

Ilustración: Psicología del color Marrón. Fuente: Belburo Studio.

Siguiendo el mismo estudio de Belburo, el color rojo (obtenido del guinda también) transmite e irradia: energía, pasión y naturaleza. Atributos que representan al condominio por sus zonas de esparcimiento que trasmiten una vibra positiva y en los cuales se te brinda la posibilidad de realizar actividades físicas en tu día a día.

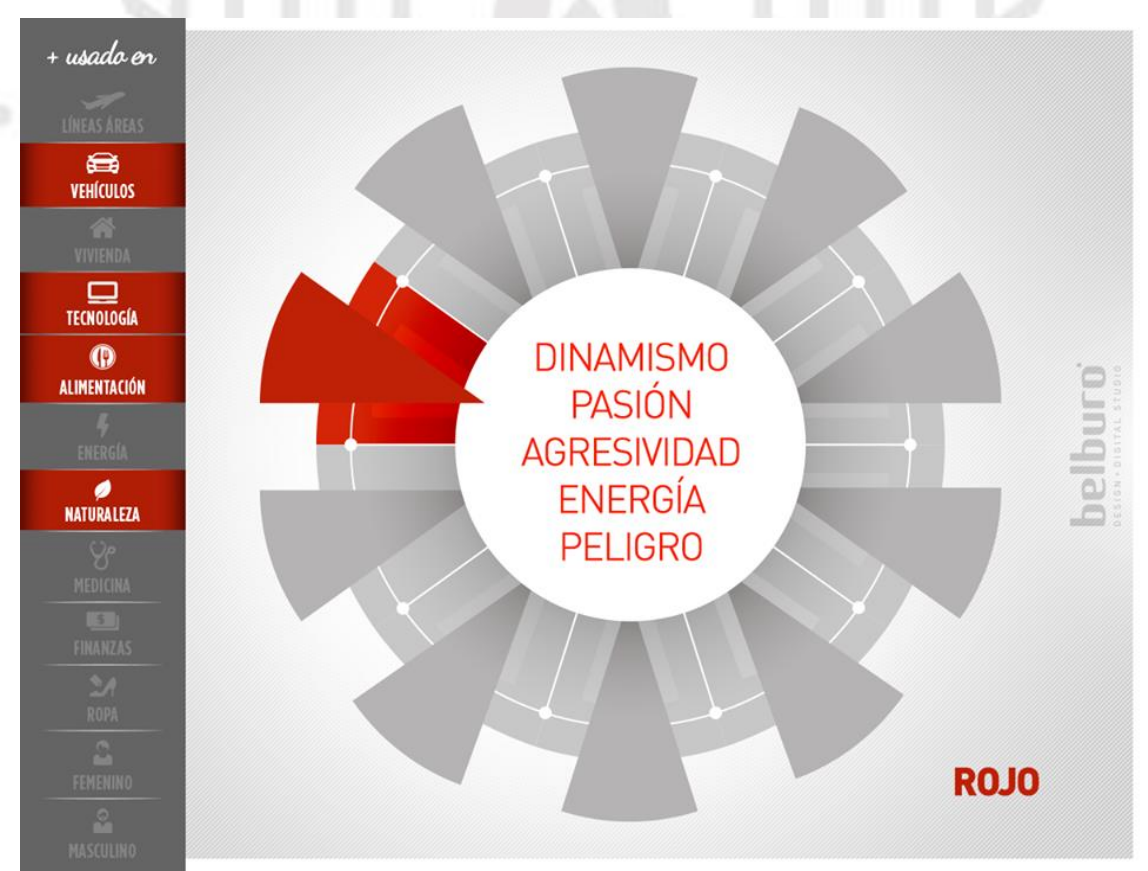

Ilustración: Psicología del color Rojo. Fuente: Belburo Studio. 
En tercer lugar, tenemos como principal fuente al color "verde" por todo lo que concierne al complejo habitacional: su inclusividad, su ahorro de energía, el contacto con la naturaleza por sus pistas para correr, manejar bicicleta y estar en contacto con el bienestar físico y la salud.

Según la "Psicología del color" libro publicado por Eva Heller (2015). Tenemos los siguientes fundamentos para colocar el color verde dentro de nuestro logo.

El verde es más que un color, el verde es la quinta esencia de la naturaleza; es una ideología, un estilo de vida: es conciencia medioambiental, amor a la naturaleza. El verde, situado en perfecta neutralidad entre los extremos, proporciona una sensación de tranquilidad y seguridad. Como el verde es el color más neutral en nuestro simbolismo, su efecto está particularmente determinado por los colores con él combinados. La combinación verde-azul domina en los acordes correspondientes a todas las cualidades positivas, aquellas que no permiten ningún grito, las que se basan en un tranquilo acuerdo: verde y azul son los colores principales de lo agradable y de la tolerancia. (p.267)

Además, el estudio de Belburo Studio (2018) sobre la psicología del color, expone en la siguiente imagen que el color verde se asocia a la vivienda, a la naturaleza y a la energía, sobre todo cuando se trata de su ahorro.

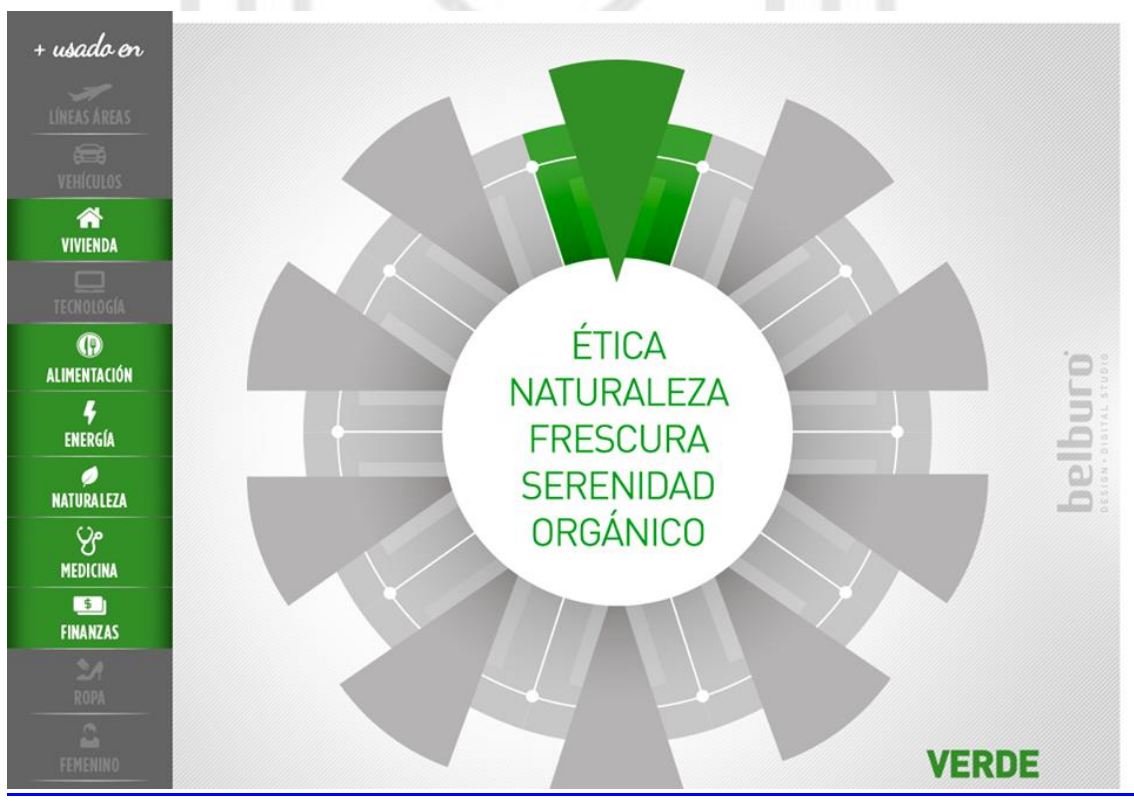

Ilustración: Psicología del color Verde. Fuente: Belburo Studio. 
Por último, el color negro que se utiliza en el logotipo secundario que dice

"Condominio", según el mismo estudio de Belburo, también se utiliza en viviendas y al mismo tiempo, refleja prestigio y valor, los cuales se le atribuyen al condominio por haber sido un complejo habitacional creado para albergas los deportistas de los Juegos Lima 2019.

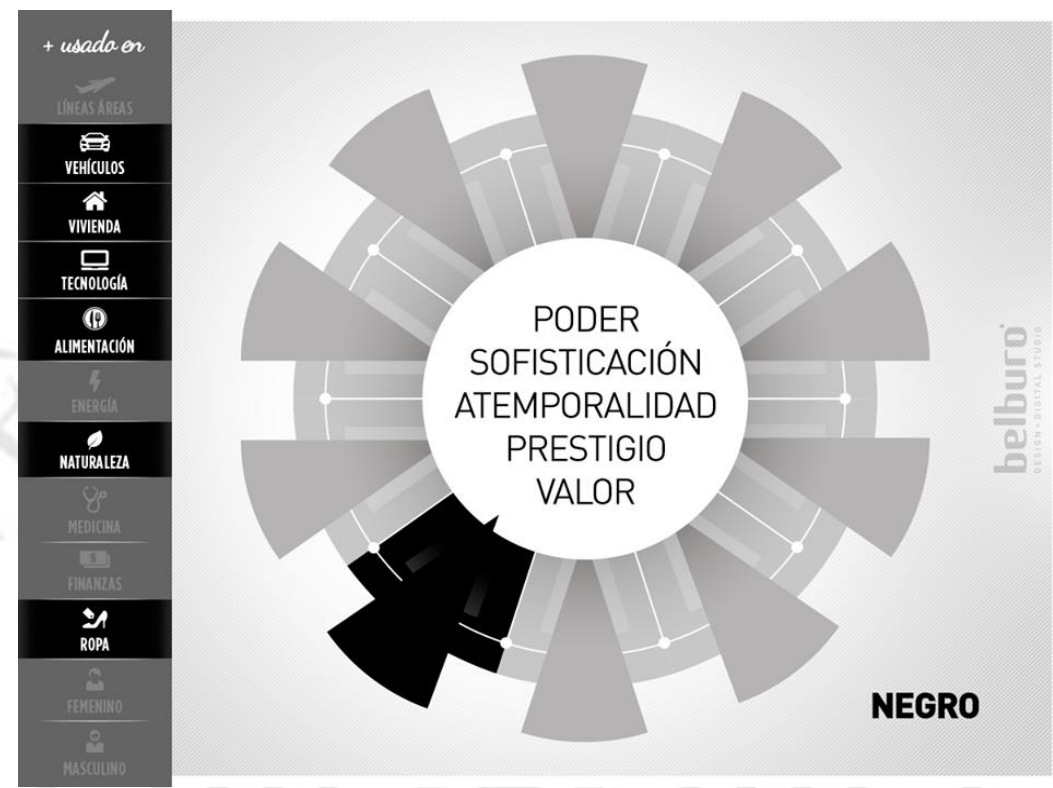

Ilustración: Psicología del color Negro. Fuente: Belburo Studio.

\section{MANUAL DE IDENTIDAD CORPORATIVO}

\subsection{Nombre}

El condominio Villa del atleta conservará el mismo nombre propuesto, ya que, al permanecer con la palabra atleta de por medio, indirectamente asocias su significado al deporte y por consecuencia a los juegos Panamericanos y Parapanamericanos que tuvieron un efecto bastante positivo en la mente de los peruanos y países invitados al evento realizado este año. En adición, la palabra "Villa" se asocia a una vivienda común donde los habitantes se sientan en familia dentro del complejo. Por lo tanto, Villa del Atleta, será una vivienda común para personas que deseen vivir en un lugar cómodo y seguro, personas que también tengan en sus planes seguir una vida saludable por los espacios en los cuales podrán cuidar de su salud física. Y al mismo tiempo, un lugar donde se podrá socializar entre los habitantes, sus familias y sus 
amigos, aportando a su salud afectiva, por los espacios y salas de reuniones que posee el condominio.

\begin{tabular}{|l|l|}
\hline \multicolumn{1}{|c|}{ Ventajas del nombre } & Desventajas del nombre \\
\hline - Se asocia a los Juegos Lima & - Podría asociarse a que solo se \\
2019 & permite ingreso a deportistas, y \\
- El término atleta podría & no es así. \\
fomentar que los habitantes & - De no utilizarse la palabra \\
tengan una vida más sana. & Condominio antes del nombre \\
Dentro del complejo & "Villa del Atleta" podría \\
habitacional. & interpretarse como un complejo \\
El término Villa se asocia a & deportivo y no como un \\
"población" por lo que la gente & complejo habitacional por ello \\
del condominio se podrá sentir & siempre irá de la mano con la \\
en familia y reforzar el hecho de & palabra "condominio". \\
cuidarse entre todos y velar por & \\
ellos mismos y sus seres & \\
queridos también. & \\
\hline
\end{tabular}

\subsection{Logo}

\subsubsection{Antecedentes del logo}

Como tenemos asociado los condominios con los juegos Lima 2019, debemos basarnos también en el logo de este evento deportivo. El logo que fue diseñado para los juegos Lima 2019, salió ganador gracias a un concurso público. Una de las características que destaco del logo de los juegos es la tipografía. Su tipo de letra es curva, no tiene terminaciones muy duras y con serifa; y cuando una marca trata de ser amigable, dinámica y empática, su tipo de letra no es tosco, sino suave, no aplica entonces un tipo de letra "serif" sino "sans serif", cuya terminación es sin serifa. 


\subsubsection{Logotipo Principal}

Para la construcción del logo tomamos elementos referidos a los siguientes puntos. En primer lugar, planteamos colocar un elemento de los Juegos Panamericanos y Parapanamericanos Lima 2019. En este caso, como se puede apreciar, decidimos incluir la flor de Amancaes, "una especie muy representada en el arte peruano y presente en poemas y canciones populares", como lo explicó en una entrevista el autor del logo, Diego Sanz. Asimismo, esta flor forma parte de la infraestructura del condominio, por lo cual obtendrá el reconocimiento respectivo y la asociación a los Juegos Lima 2019. Decidimos varias sus colores originales a las tonalidades crema y marrón y colocarle el tipo de opacidad en "multiplicar" para adherirlo de forma que se sienta parte del edificio.

Por otro lado, necesitábamos incorporar el tema de una vivienda eco-amigable, que se preocupa y vela por tu salud, relacionados a nuestra esencia. Por lo tanto, al momento de armar el logotipo recurrimos a utilizar una tonalidad verde en la tipografía y negra en el logotipo secundario porque ese color también se le asocia a las viviendas y denota el prestigio, como anteriormente se explicó.

- Isologotipo:

El isologotipo es la mezcla del isotipo con el logotipo. 


\section{CONDOMINIO}

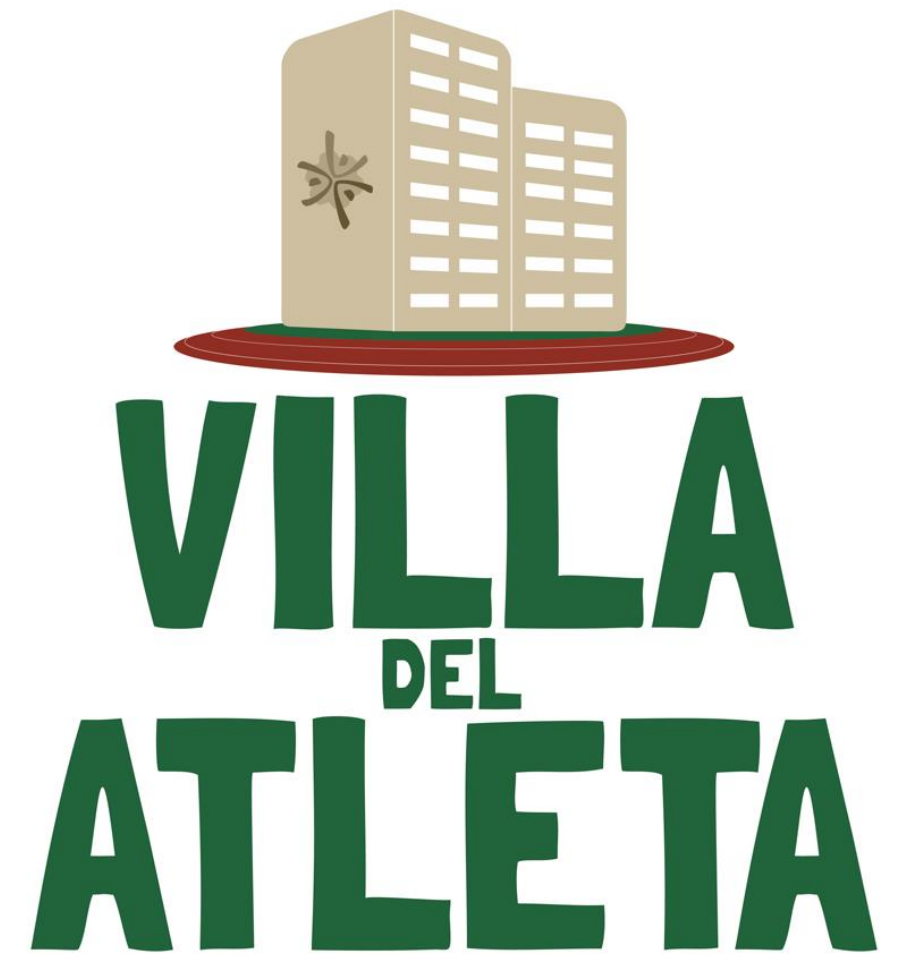

Ilustración 1: Isologotipo Villa del Atleta. Fuente: Propia

- Logotipo:

Dentro del logotipo, tenemos dos tipos de tipografía. La principal: Villa del Atleta y la secundaria que va en "Condominio".
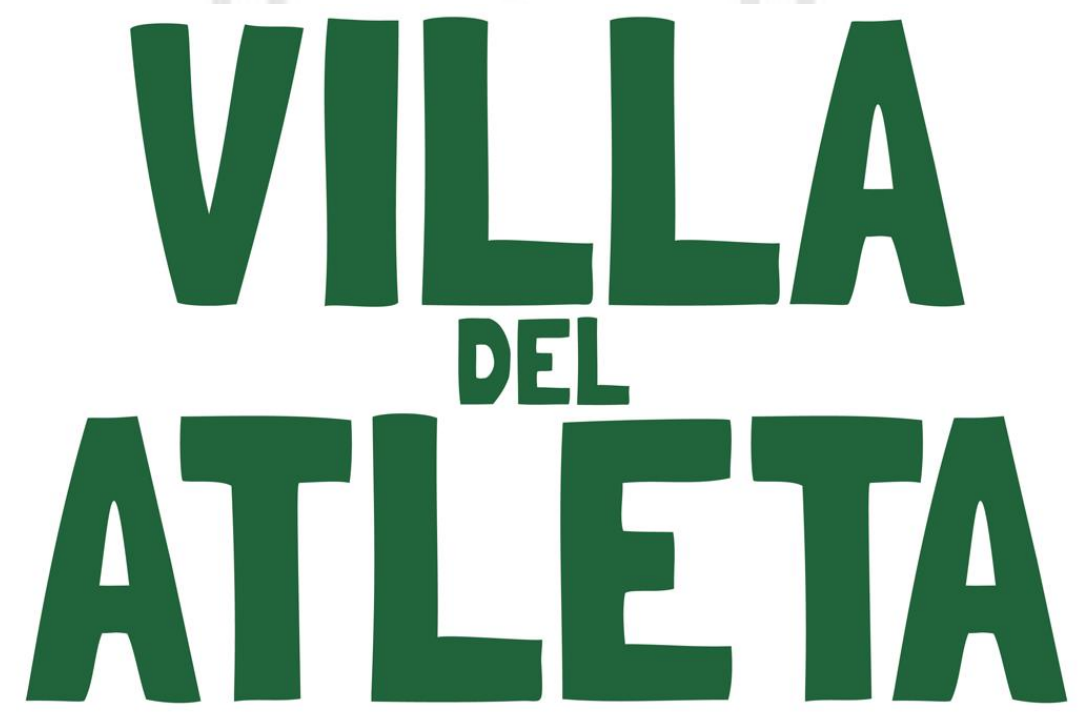

Ilustración 2: Logotipo principal Villa del Atleta-Londrina Solid. Fuente: Propia. 


\section{CONDOMINIO}

Ilustración 3: Logotipo secundario Condominio- Gill Sans MT (BOLD). Fuente: Propia.

- Isotipo

El isotipo es nuestro definido "icono" que comprende el isologotipo. Este representa las torres conglomeradas en medio de una pista atlética, ello refiriéndose a los Juegos Lima 2019 y también porque se ofrece zonas donde los residentes puedan hacer ejercicio dentro del complejo habitacional.

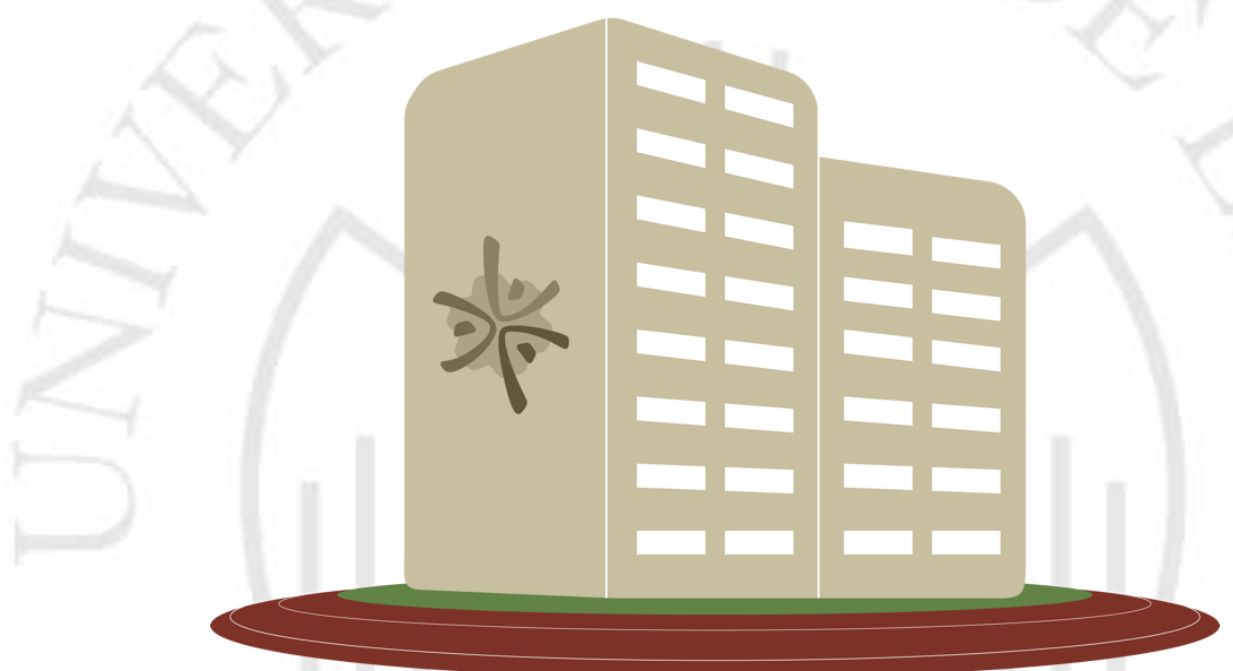

Ilustración 4: Isotipo Condominio Villa del Atleta. Fuente: Propia.

\subsection{Variantes del logo}

El logo se podrá utilizar con los fondos de los colores corporativos tanto en posición vertical (la principal) como en posición horizontal. 


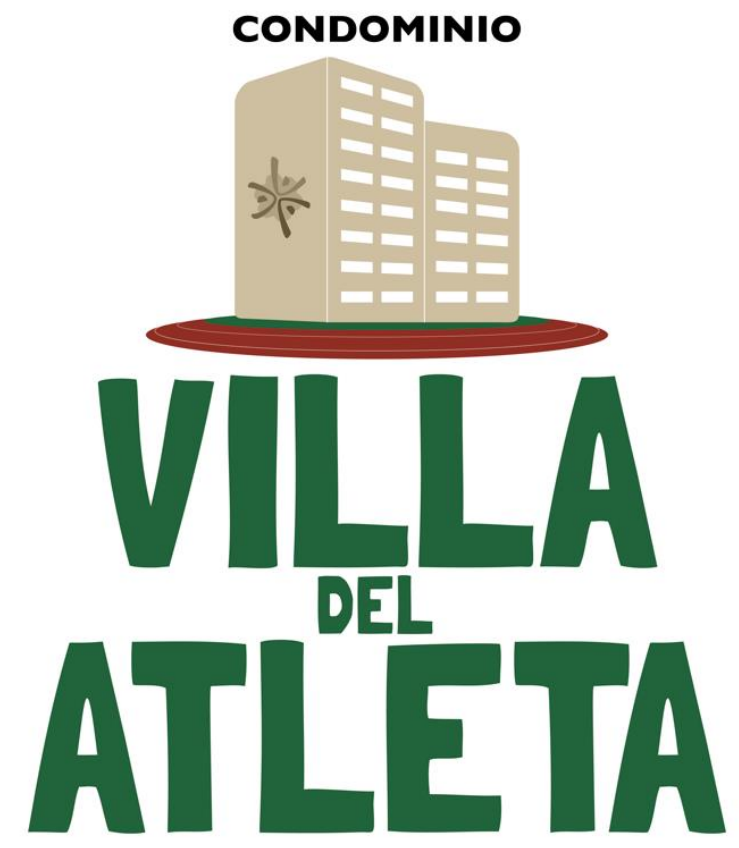

Ilustración 5: Logo principal: Condominio Villa del Atleta. Fuente: Propia.

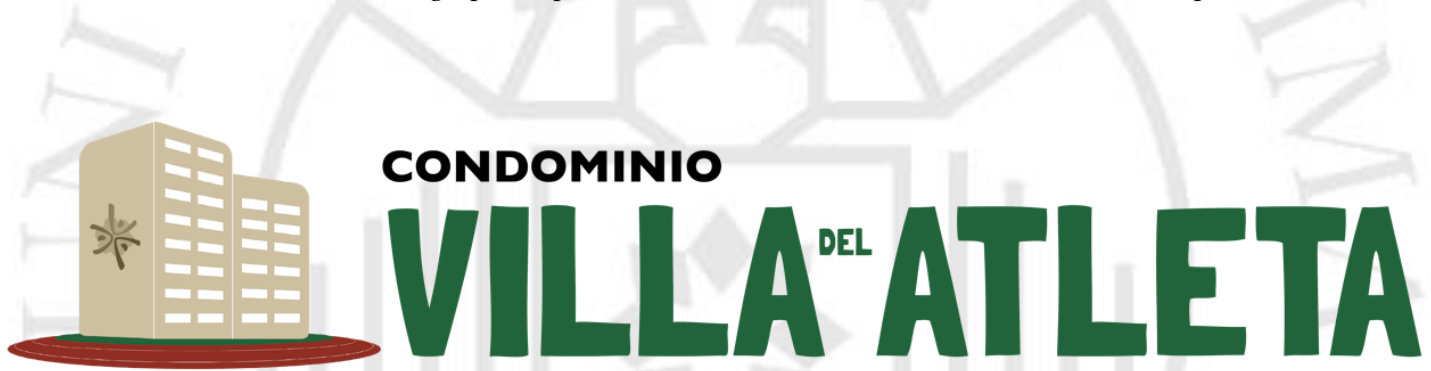

Ilustración 6: Logo Secundario: Condominio Villa del Atleta. Fuente: Propia.

\subsection{Variantes del logo en positivo y negativo}

El logo podrá utilizarse tanto en positivo como en negativo, más no en escala de grises. Ambos logos, el principal y el secundario podrán variar de positivo a negativo. 


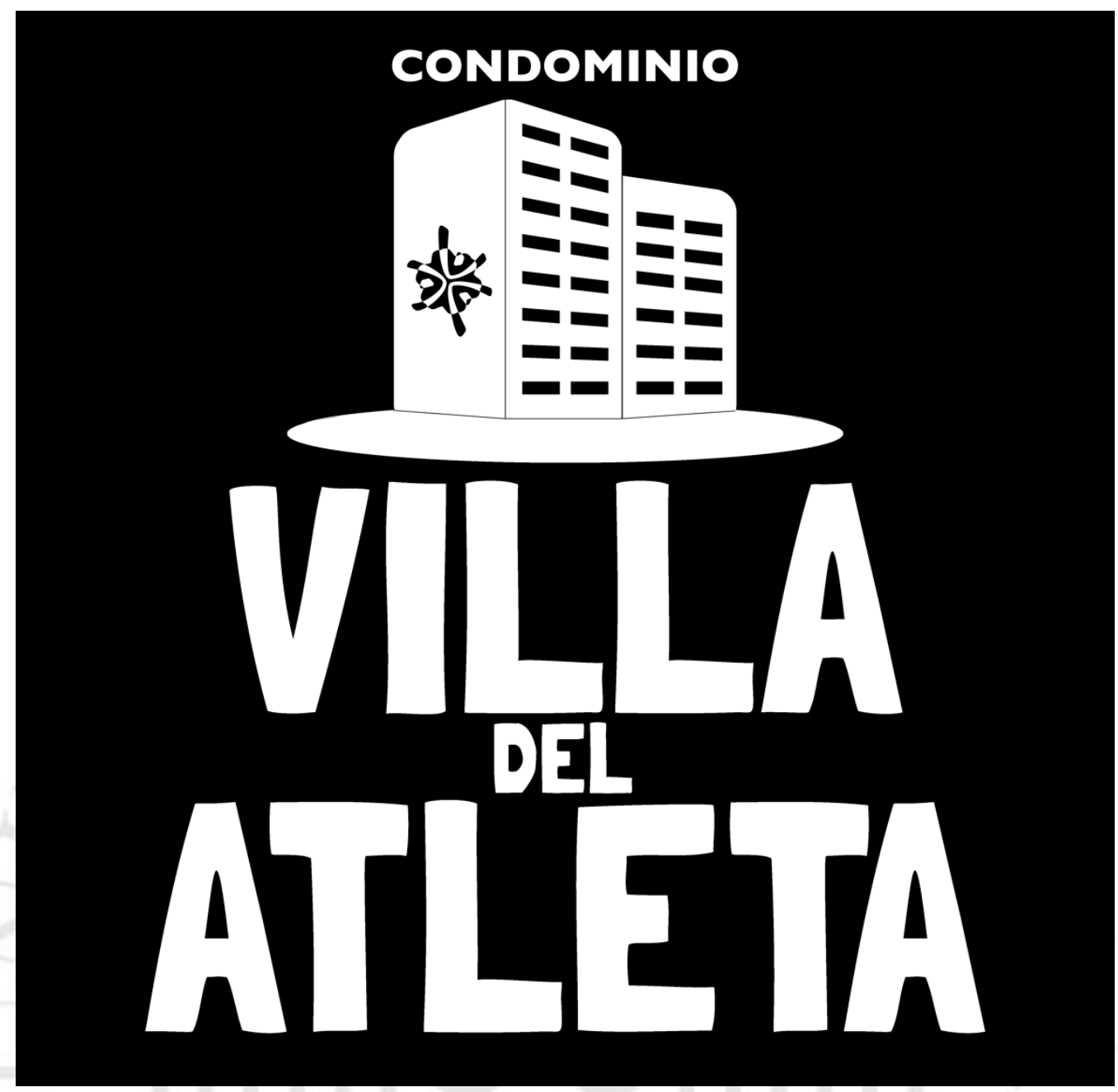

Ilustración 7: Logo en negativo principal: Condominio Villa del Atleta. Fuente: Propia.

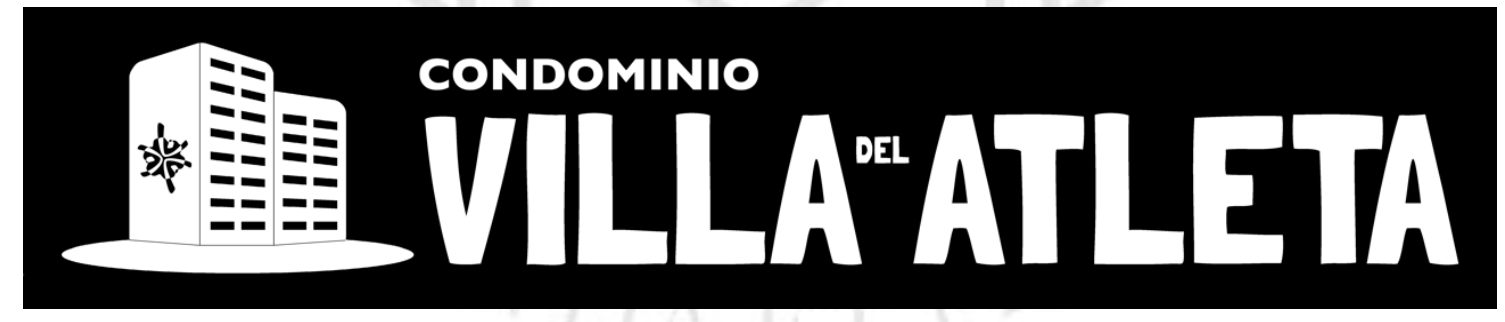

Ilustración 8: Logo en negativo secundario: Condominio Villa del Atleta. Fuente: Propia. 


\section{CONDOMINIO}

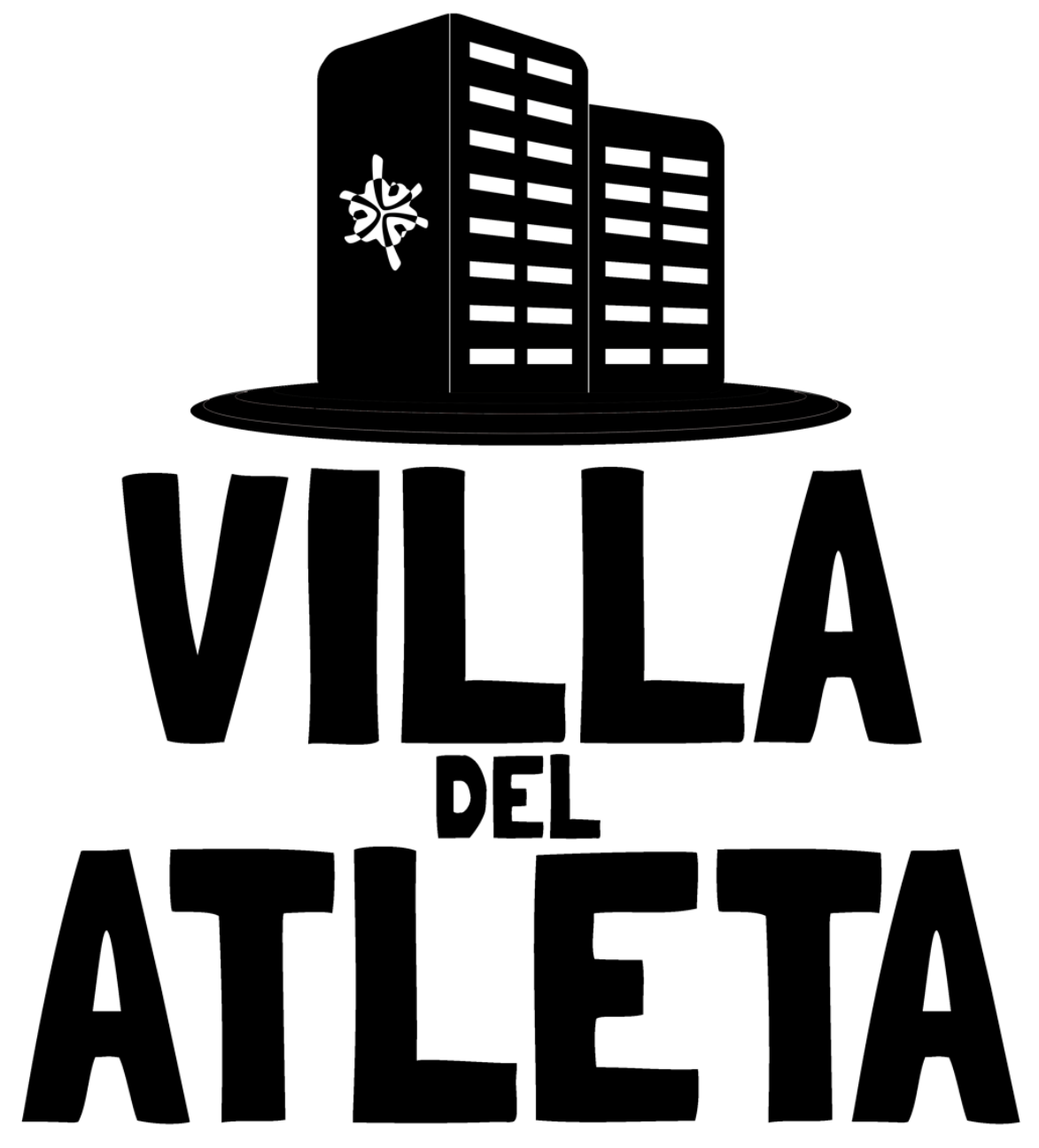

Ilustración 9: Logo en positivo principal: Condominio Villa del Atleta. Fuente: Propia.

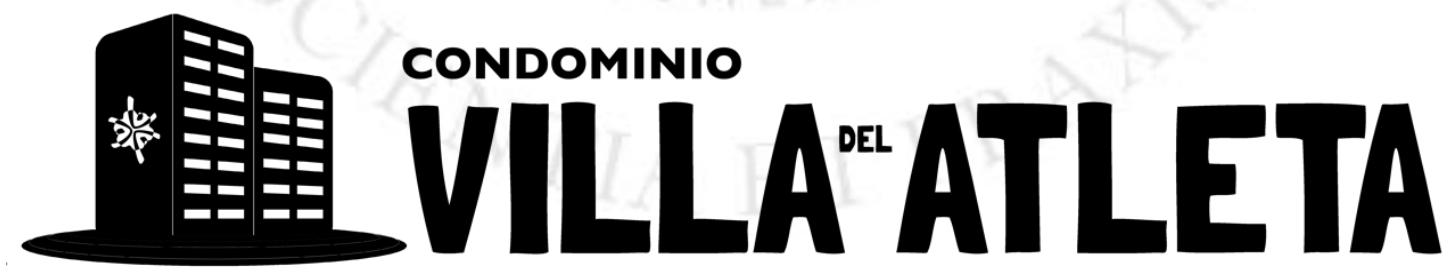

Ilustración 10: Logo en positivo secundario: Condominio Villa del Atleta. Fuente: Propia. 


\subsection{Valores del logo}

- Armonía

- Disciplina

- Inclusión

- Tolerancia

- Sostenibilidad

\section{La Campaña}

\subsection{Objetivos}

\subsubsection{Objetivo de Marketing}

Lograr la venta del $100 \%$ de los departamentos del Condominio Villa del Atleta. La campaña se iniciará en enero del 2020 y la venta de todo el condominio se estima concluir máximo el 30 de Junio del año 2020, finalizando el segundo trimestre del año.

\subsubsection{Objetivos de comunicación}

a) Dar a conocer el proyecto y sus características hasta antes de marzo del 2020.

b) Motivar al target a adquirir cada uno de los departamentos para el segundo trimestre del 2020.

c) Comunicar al target acerca de las modalidades de financiamiento a través del programa Mi Vivienda cada vez que se realice una cotización o se reserve una cita.

\subsection{Público Objetivo:}

Jóvenes y adultos desde los 25 hasta los 55 años de edad en adelante, de los NSE C y D. Todo aquel que tenga el anhelo de adquirir una vivienda propia. El público objetivo se dividirá en dos. En primer lugar, nuestro Público Objetivo Primario son las parejas de 
jóvenes-adultos entre los 25 a 35 años de edad que tienen un estilo de vida moderno, están al tanto de la coyuntura y en su mayoría tratan de llevar una vida saludable. Estos jóvenes adultos están al tanto de los medios digitales y pasan su tiempo libre en distintas redes sociales y páginas web.

Por otro lado, el público objetivo secundario son parejas de adultos mayores desde los 35-55 años.

Nuestro público objetivo secundario son adultos mayores desde los 35 años hasta los 55 años. Este público es un sector maduro que busca tener una vivienda factible a sus necesidades y su comodidad. Ellos buscan una vivienda que les proporcione seguridad y el condominio Villa del atleta con el posicionamiento que tiene, lo brinda. Y no es solo el posicionamiento, sino también la infraestructura amplia pensada para todo público. La Villa del atleta proporciona espacios especiales en los cuales una persona con discapacidad podrá transitar con la mayor comodidad y tranquilidad posible. Por lo tanto, si un adulto mayor que padece alguna discapacidad decidiera vivir en el condominio, tendrá un espacio en el cual sentirse en casa y sentirse como un campeón, puesto que, al demostrarle que pensamos en ellos y su comodidad, le estimularemos el sentido empático y gustará de vivir en los departamentos. Asimismo, cabe resaltar que no solo nos basamos en espacios amplios para personas con discapacidad, sino también simpatizamos con adultos que deseen vivir en pareja, solos o tener a su familia con ellos y que sus nietos puedan encontrar en el mismo condominio muchos espacios en los cuales desarrollar sus actividades motoras y poder jugar o hacer ejercicio o ser parte de una sociedad dedicada al cuidado de su salud y que te brinda la facilidad de poder cuidarte.

En adición, se hará un listado de las características sociodemográficas que pudimos concluir a partir de los diferentes estudios y recompilación de datos de nuestro P.O:

- Les interesa mucho vivir en un departamento propio.

- Utilizan sus smartphones y navegan por el Internet con regularidad diariamente.

- Escuchan radio y les transmite seguridad lo que se comunica a través de ese medio.

- Les gusta tener a su alcance espacios que mejoren su calidad de vida y que beneficien a a su necesidad de socializar. 


\subsection{Concepto}

"Vive en familia como un campeón"

Este concepto parte de la coyuntura latente que nos dejaron los Juegos Panamericanos y Parapanamericanos 2019. En primer lugar, desglosaré el significado de la siguiente frase, el concepto de vivir en familia equivale a sentirse parte de una sociedad, de un entorno familiar, tal vez no necesariamente que vivas con tu familia pero sí sentirte en un hogar real, como te sentías en casa de pequeño, donde estarás cómodo, sentirás que velan por ti y te sentirás parte de una pequeña sociedad dentro del mismo Condominio. Y por otro lado, la frase como un campeón denota dos variantes. El primero es relacionado a los juegos, ya que los medallistas de oro peruanos tienen departamentos en la Villa del Atleta y se le asocia que literalmente vivirás como un "campeón”. Y en segundo lugar, “como un campeón" se utiliza como una metáfora que se asocia al sentirnos cuidados, que velan por nuestra salud, que estamos viviendo en un hogar que cuida de ti. Eso queremos dejar marcado con la frase. Por esta razón, se decide implementar dentro de las piezas creativas, las personas llevando alrededor de sus cuellos unas medallas de oro, con este elemento se reforzará el sentir que genera la frase "como un campeón" y se complementa con las actividades cotidianas y sociales como pasar tiempo con tu familia, sentirte cómodo, a gusto, seguro, como cuando te sentías engreído en casa de pequeño. Asimismo, también se le da un giro a la palabra campeón en cuanto al precio, porque nosotros nos encargaremos de ayudarte a cotizar el depa a través del financiamiento del Nuevo Crédito Mi Vivienda, para que la mensualidad salga a un precio totalmente alcanzable y el ganador será la persona interesada, puesto que habrán obtenido un premiaso y se sentirán unos campeones.

\subsection{Estrategia de Comunicación}

Para el planteamiento de las estrategias de comunicación se recopilarán todos los datos utilizados dentro de los análisis de la situación actual, la competencia, perfil del usuario, etc. Para el planeamiento de las estrategias tomaremos en cuenta los objetivos que tenemos de marketing y de comunicación. 
En primer lugar, después de haber identificado nuestra audiencia lo que necesitamos es descomponer estos objetivos en mensajes para cada uno de los públicos, estos mensajes tendrán que llegar a ellos a través de los distintos canales de comunicación.

En cuanto a las piezas publicitarias, decidimos incorporar los siguientes elementos para darle unidad a las piezas publicitarias: familias felices, que se vean cómodas en familia, disfrutando de la compañía de sus seres queridos, la accesibilidad que se propone al colocar un precio tentativo, al alcance del sector y sobretodo, se utilizará el recurso de la metáfora con las medallas, antes mencionada, la cual implícitamente denota que el consumidor vive como un campeón dentro del Condominio Villa del Atleta. Asimismo, además de incorporar la música tranquila, alegre y motivacional a los videos de las redes y la publicidad radial(que se explicará aún más en el apartado de medios), se harán presentes los colores del logo dentro de las gráficas, el tipo de letra secundario y primario del logo; todo con el fin de reforzar la marca, seguir sus lineamientos y promover su recordación.

Por otro lado, se especificará en el apartado de Presupuesto, el calendario y/o frecuencia de los medios y su circulación. En adición, en el siguiente cuadro colocaremos las acciones a realizar para conseguir los objetivos, sus acciones, mensajes, recursos asignados, presupuesto y tiempo. 


\begin{tabular}{|c|c|c|c|c|}
\hline$E$ & 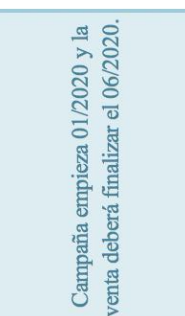 & 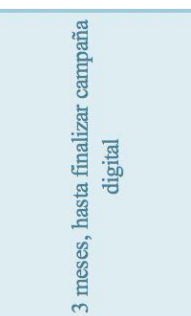 & 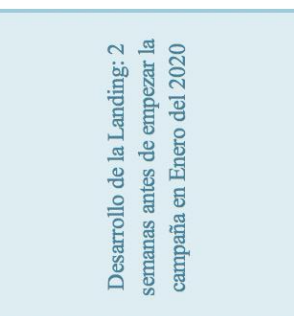 & 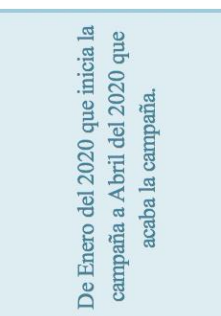 \\
\hline$\frac{2}{2}$ & 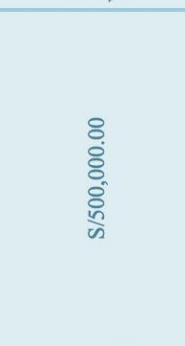 & 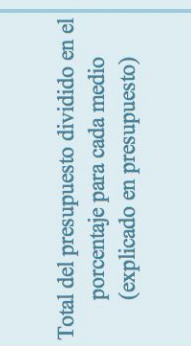 & 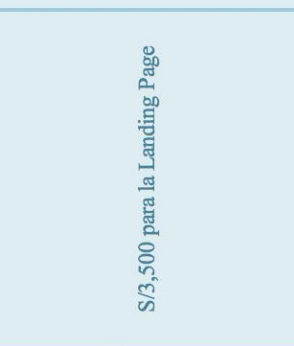 & 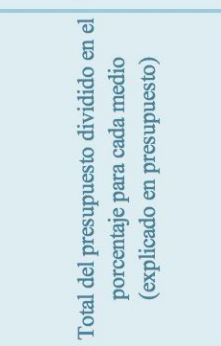 \\
\hline$\frac{1}{2}$ & 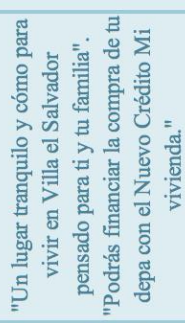 & 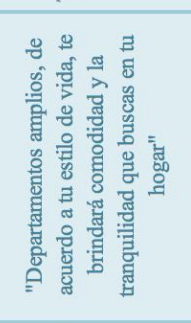 & 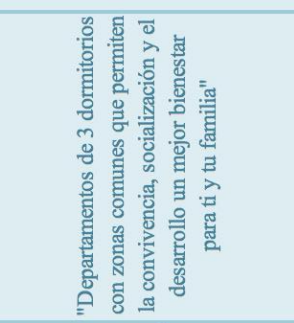 & 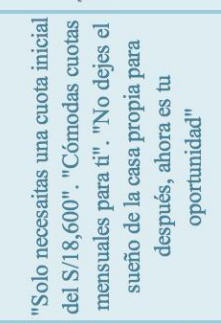 \\
\hline 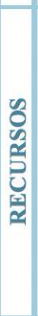 & 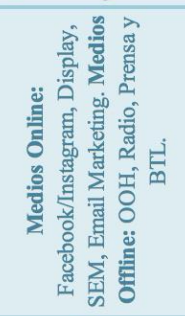 & 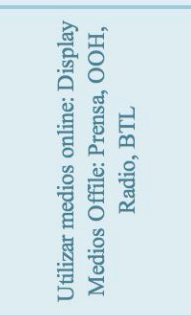 & 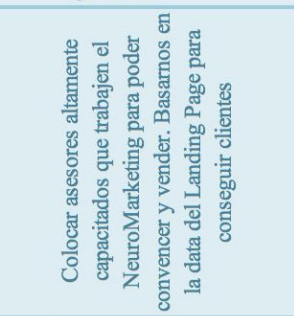 & 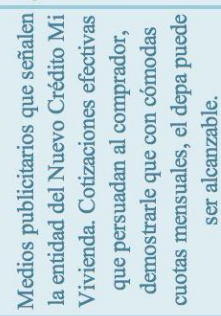 \\
\hline $\begin{array}{l}\mathrm{z} \\
\mathrm{d} \\
\mathrm{d}\end{array}$ & 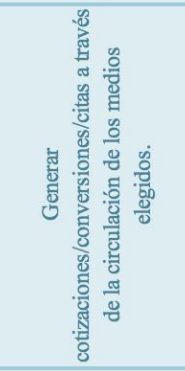 & 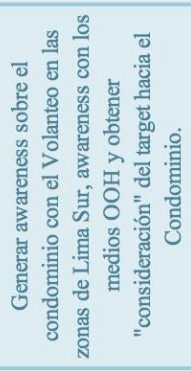 & 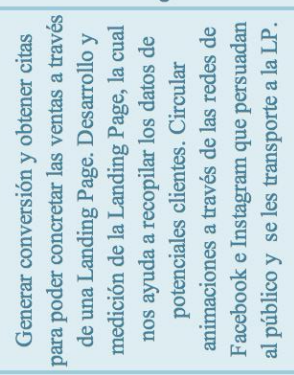 & 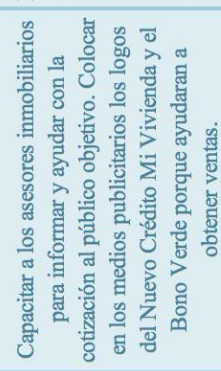 \\
\hline & 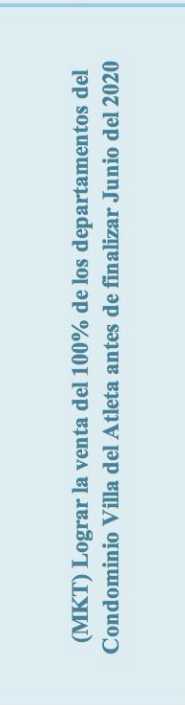 & 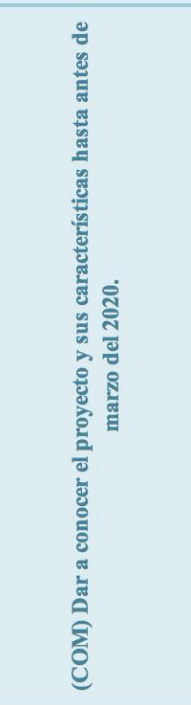 & 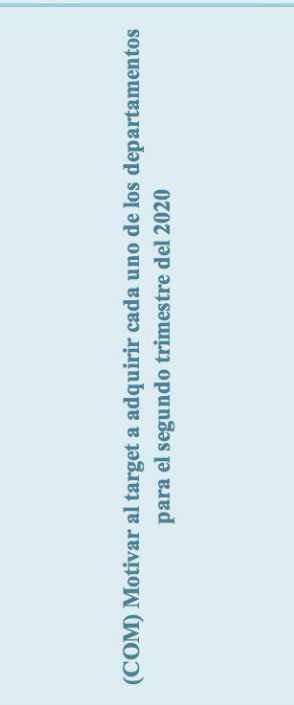 & 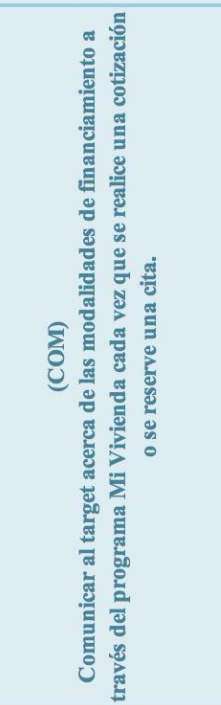 \\
\hline
\end{tabular}

Tabla: Estrategias de Comunicación. Fuente: Propia. 


\subsection{Estrategia de medios}

Según un estudio de IPSOS (2017) denominado: "La importancia de una adecuada estrategia 360", se expone lo siguiente.

Tradicionalmente las estrategias de medios habían estado separadas por el uso de estrategias divididas en los medios masivos tradicionales y los no convencionales. Sin embargo, a raíz del surgimiento de los denominados medios ATL (Above The Line) y BTL (Below The Line) y con el desarrollo de nuevos medios de comunicación, se abre un sin número de posibilidades en el desarrollo de estrategias 360 grados, en donde se puede utilizar una mezcla de medios ATL y BTL de manera que se pueda atacar al consumidor desde diferentes flancos con el fin de lograr una mayor efectividad en la recordación, imagen de marca, consumo y lealtad de nuestros productos" (p.2)

Nuestros medios digitales circularán desde enero a marzo y nuestros medios off-line se establecerán desde febrero y terminarán en abril, a excepción del volanteo de flyers, el cual empezará al mismo tiempo que digital en la zona de Lima Sur, sobretodo en centros comerciales como el Mega Plaza, Plaza Lima Sur y otras zonas aledañas donde circulen muchos transeúntes.

Se decide iniciar la campaña con los medios digitales porque de acuerdo a ello podemos tener un escenario inicial del mercado y la respuesta que brinda a los estímulos que le persuadimos en los medios digitales. Y, a través de esa respuesta, podemos ver cómo es que se incrementa o mejora el ritmo de la conversión y las ventas al poner en marcha los medios off-line. Esto nos servirá para poder armar seguir desarrollando un modelo de atribución preciso que nos impulse al objetivo de la venta total del Condominio.

Por esta razón, nos hemos embarcado en una campaña mixta tanto con medios online como offline. 


\subsection{Ecosistema de medios}

\section{Medios Offline}

- Prensa (Objetivo: Awareness y Cotización)

- $\mathrm{OOH}$ (Objetivo: Awareness y consideración)

- BTL/Volanteo (Objetivo: Awareness y consideración)

- Radio (Objetivo: Awareness y consideración)

\section{Medios Online}

- Desarrollo Landing Page (Objetivo: Consideración y cotización)

- Email Marketing (Objetivo: Consideración y cotización)

- Facebook/Instagram (Objetivo: Consideración y cotización)

- Display (Objetivo: Awareness y consideración)

- SEM (Objetivo: Consideración y cotización)

De acuerdo al siguiente planteamiento, ¿cuáles serán nuestros medios centrales y cuáles los secundarios?

Medios principales/ejes: Facebook (20\%), Display (20\%), SEM (15\%), Radio (16\%) y Prensa (18\%). Los mencionados son nuestros medios ejes, ya que se llevan el grueso de nuestro presupuesto. Ellos nos ayudarán a alcanzar un mayor porcentaje de conversión y posteriormente a obtener resultados y la venta total esperada antes de finalizar Junio del 2020. A estos medios los elegimos como pilares motivadores a objetivos porque, como comentamos anteriormente en el perfil del público y en el análisis sociodemográfico, son medios en los que nuestro público cree, medios que suele visitar con frecuencia, medios que generan una mayor recordación, medios en los que confía y medios con los que convive en su día a día. Por otro lado, se debe integrar en los medios ejes a la Landing Page, porque aunque nuestro presupuesto solo haya destinado el $1 \%$ en su creación, esta página será la que reciba los CTA que nos otorgará clientes interesados, nos permitirá poder obtener una cita o realizar una cotización y finalmente, será de ayuda para poder cerrar una venta.

Medios secundarios: Medios OOH (4\%), Email Marketing (3\%) y BTL/ Volanteo (4\%). Se les atribuye como medios secundarios porque no hemos necesitado destinar una 
cantidad fuerte del presupuesto para poder obtener beneficios al hacer uso de ellos. Aunque sean medios alcanzables en cuanto al presupuesto, los beneficios que ellos nos traen también aportan beneficiosamente a la estrategia de comunicación. Por ejemplo, los medios $\mathrm{OOH}$, generarán awareness y consideración para la compra de uno de los departamentos. Email Marketing nos da grandes beneficios cuando la segmentación es precisa, ya que, al ser un medio de comunicación directo, puede generar que un lead se convierta en una venta en poco tiempo estimado. Por último, el volanteo despertará el interés del público objetivo al desarrollar una necesidad: querer obtener tu departamento propio a un precio bastante considerable donde podrás vivir cómodo y tranquilo.

\subsection{Presupuesto}

En cuanto al planteamiento del presupuesto, se decide dividir la campaña en los meses de enero febrero marzo y abril. Durante esas 16 semanas, tanto la campaña off-line como la online se pondrán a circular. Esta campaña de comunicación empezará desde el 5 de Enero y terminará el 26 de abril.

En una primera instancia, se debe tener en cuenta que por más que la inmobiliaria que nosotros dirigimos cuente con diseñadores, se necesitará la creación de una Landing Page, con propio dominio y hosting, en la cual basaremos toda nuestra publicidad digital. La creación de esta página está planteada para estar movimiento ni bien inicie la campaña el 5 de Enero. Lo que buscamos con nuestra Landing Page será generar una cotización, donde podamos obtener los datos del cliente como nombre, DNI, su número y hasta su correo. 


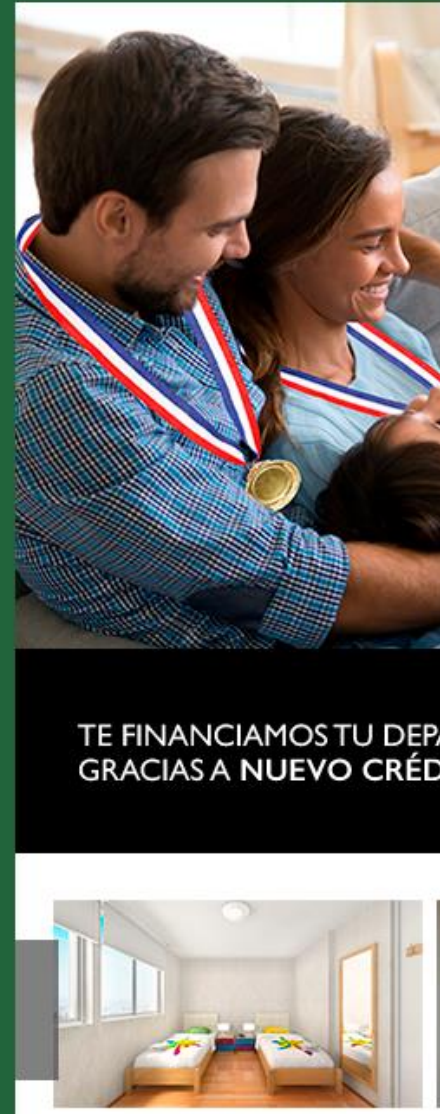

DORMITORIOS

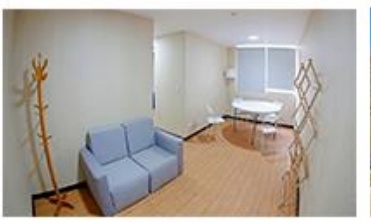

SALAS

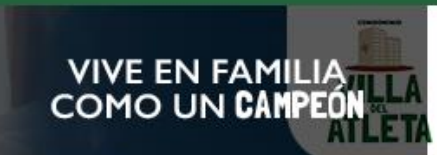

Nombre

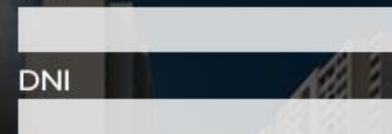

Celular

Correo

\section{TE LLAMAMOS}
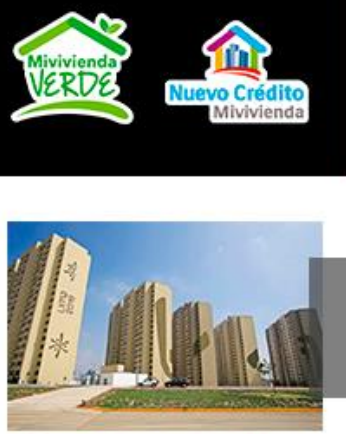

ÁREAS COMUNES

- 3 dormitorios

- Condominio inclusivo para personas con discapacidad

- Extensas habitaciones y pasillos

- Pista atlética y de bicicleta

- Gimnasio

- Áreas comunes

- Seguridad las 24 horas

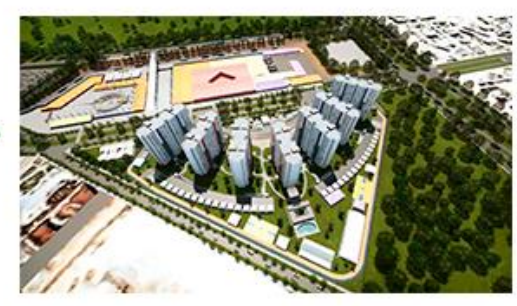

\section{COTIZA HOY}

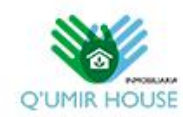

Ilustración: Landing Page. Fuente: Propia 
De acuerdo a esto, nosotros nos pondremos en contacto con nuestros potenciales clientes y los convenceremos gracias a nuestros asesores inmobiliarios, quienes destacaran todas las facultades de nuestros departamentos y reducirán cualquier temor que pueda acontecer a nuestro target a través de un excelente trabajo de Neuromarketing.

Según Roberto Blanco en su libro "Cómo vender el cerebro" (2018) Neuromarketing tiene la siguiente definición:

El neuromarketing se define como la disciplina que investiga y estudia los procesos cerebrales que explican la conducta y la toma de decisiones de las personas dentro de las áreas de acción del marketing tradicional, como son la inteligencia de mercado, servicios, precios, posicionamiento, branding, diseño de productos, canales y ventas. (p.93)

Entonces, el Neuromarketing ataca la mente del consumidor jugando básicamente con sus pensamientos. De acuerdo a ello, tendríamos que no prometer nada y cubrir una necesidad que está en el corazón de la gente. Asimismo, basarnos en entender las profundidades del inconsciente y subconsciente de las personas.

Y ¿de qué manera podrían nuestros asesores introducirse en nuestro target?

En primer lugar, reduciendo el miedo que tienen las personas al cumplir la promesa que estemos dando. Seguidamente, ahorrarle energía; es decir, presentarles una oferta accesible o las oportunidades de obtener un departamento propio a través del nuevo Crédito Mi Vivienda que propone también descuentos como el Bono Verde y el Bono del Buen Pagador. Por último, habrá que aumentarle el placer a la persona mostrándole lo que espera recibir (como los salones, salas de juego, el gimnasio, etc) o tal vez no lo esperaba, pero llegamos a introducirlo en la mente del target como una necesidad. Entregar valor y obtener valor. Eso es vender. 


\section{Etapas de la campaña}

\subsection{Primera Etapa: Online}

Decidimos empezar a captar a nuestro target en el primer mes de Enero a través de una campaña con medios online. Esta misma tendrá un porcentaje del $59 \%$ de nuestro presupuesto planteado de 500.000 soles. Ese $59 \%$ Se dividirá a lo largo de tres meses, es decir que partirá desde enero hasta marzo del 2020. La razón por la cual decidimos invertir el $59 \%$ en nuestros medios online es porque nuestro público objetivo está muy conectado a las redes sociales e Internet en general y, además de eso, la gran mayoría cuenta con smartphones desde donde se conectan por semana al tratarse de un medio con un alcance considerable, a diferencia de las laptops o computadoras, las cuales no te permiten tanta facilidad de llevar consigo.

Dentro de los medios digitales que se utilizarán, dejando de lado la creación de la Landing Page, Utilizaremos Facebook, display, SEM, y por último email marketing.

Por lo tanto, en el ámbito digital haremos uso del 59\% de nuestro presupuesto de S/ 500,000. En suma, se plantea que el grueso de nuestro presupuesto sea destinado a Facebook, con un 20\%, y a display, con el mismo porcentaje

\subsection{Propuesta de medios digitales}

\subsubsection{Email marketing:}

Se trata de uno de los medios que ataca directamente al target, aunque suele considerarse invasivo, si se le realiza de una forma llamativa e interesante, puede obtener resultados altamente beneficiosos. Se invertirá un $4 \%$ del presupuesto total planeado para Email Marketing. Asimismo, las empresas a las que otorgaremos el planeamiento de MM son Perú Total, con una inversión aproximada de S/9,000.000, y Mailing top, con un 40\% de la inversión de MM. 


\section{Propuesta}

Lead de email marketing, adaptado a mobile, imagen debe incluir nuevo crédito mi vivienda/ mi vivienda verde, con copys que llamen la atención de nuestro target y un Call to Action que lo redirija hacia la landing page.

\section{Potenciales copys}

Tu depa propio solo con S/18600 de inicial. (Enfocado al precio)

-Vivir saludable ahora es más sencillo desde la Villa del Atleta-emoji depa, -emoji green(Enfocado al Target estilo de vida saludable)

- Vive en familia como un campeón (Emoji medalla + emoji casa) (Enfocado al concepto)

- El lugar perfecto para vivir en Villa el Salvador (Enfocado al target demográfico)

\subsubsection{Facebook}

Nuestro público objetivo del sector socioeconómico C y D es partícipe de las redes sociales, encabezando Facebook y siguiéndole Instagram.

Dentro de estas dos redes, colocaremos anuncios llamativos para nuestro target donde se aprecien las cualidades del Condominio Villa del Atleta.

Se invertirá $20 \%$ de nuestro presupuesto total en Facebook, del cual $80 \%$ se le destinará a Facebook porque es la red social principal que tiene mayor uso y alcance; y $20 \%$ a Instagram para igual atacar ambas redes sociales y tener mayor oportunidad.

Los anuncios aparecerán tanto en el feed de Facebook, como en el feed de Instagram. En un formato $1200 \times 1500$, el cual se interpreta como un 2:3 vertical, que ocupa el $75 \%$ de la pantalla del celular aproximadamente.

En cuanto al planteamiento de la animación que se circularía en Facebook e Instagram, se decidió optar por 2 videos, con un máximo de 15 segundos, destinados a los dos públicos objetivos: primario y secundario. Ambas animaciones tendrán el contenido similar, a excepción de una de sus escenas. Gracias a que Facebook nos permite delegar 
un anuncio por público específico, la animación para el Público Objetivo Primario tratará de llamar la atención del potencial comprador con una pregunta en los primeros 2-3 segundos del video, seguidamente se mostraran las cualidades del Condominio que profundizan la idea de "vivir en familia como un campeón": Estar cómo con tu familia, tener espacios amplios para pasar tiempo de calidad, etc. Además, cabe resaltar que las animaciones culminarán con un CTA hacia la landing page, que lleve a los interesados a cotizar y obtener una cita que permita concretarse en una venta.

Link de animación para P.O.P:

https://drive.google.com/open?id=110_sO3LB8cdjf4nLX6MZnGg6fEDUB3EI

Link de animación para P.O.S:

https://drive.google.com/open?id=1n6deDJXzOqEyOeW--SAMfa-LPjHT_gsp

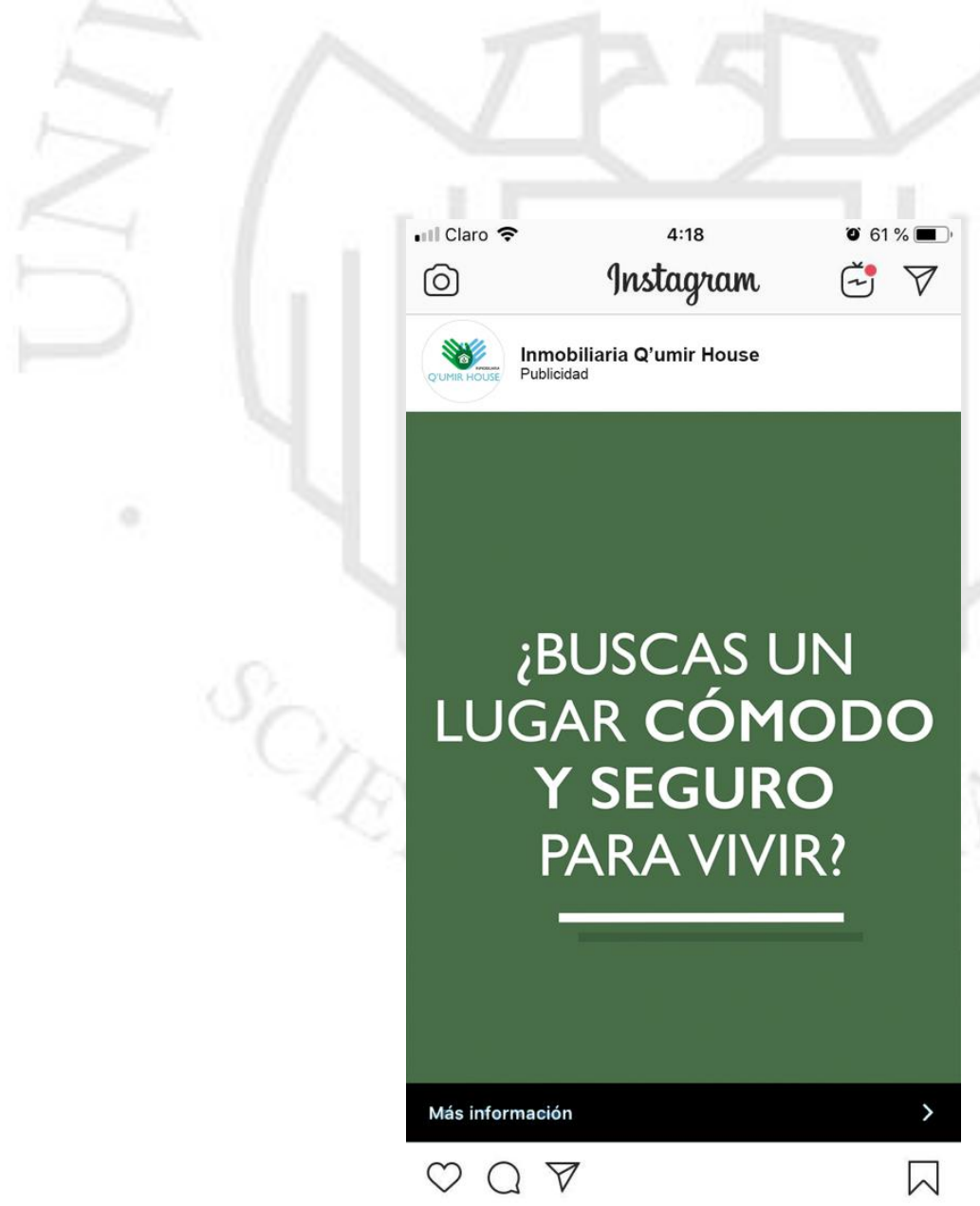

Ilustración: Feed Instagram. Fuente: Propia. 


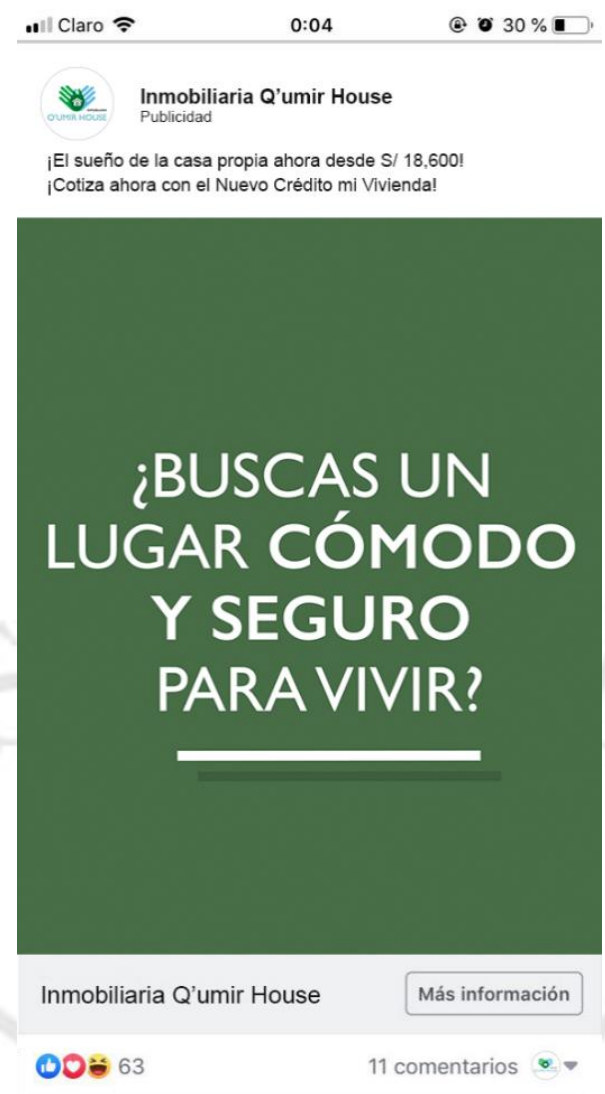

Ilustración: Feed Facebook. Fuente: Propia.

\subsubsection{Display:}

Un banner o display es una herramienta bastante útil que se utiliza en páginas que podrían interesarle a nuestro público objetivo debido a que se trata de un medio que atrae la mirada al consumidor debido a su inmediata aparición. Este medio recibirá otro grueso denuestro presupuesto total ya que se lleva el $20 \%$ de nuestra inversión.

Trabajamos con nuestro proveedor Peru Red, quienes nos facilitaron colocar banners rectangulares/cuadrangulares en formato gif. A medida que el lector y potencial comprador visualice notas o noticia, el display se podrá apreciar. Asimismo, se propone colocar un gif, ya que después de visualizar lo que dice la imagen, aparecerá un botón (a lo largo de toda la imagen) que diga "Más información”. Este supuesto botón aterrizará en la landing page. 


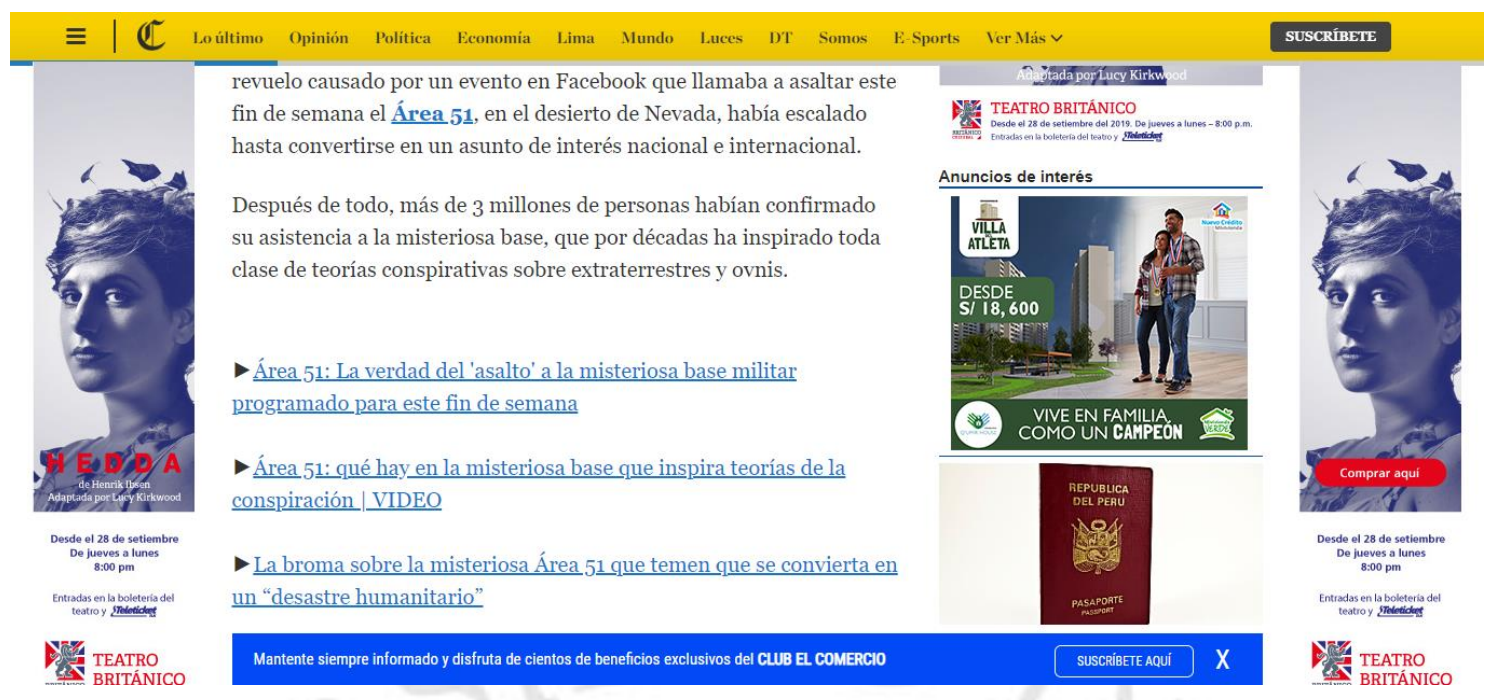

Ilustración: Display de Perú Red en El Comercio. Fuente: Propia.

\subsubsection{SEM}

Google Adwords es uno de los medios que permite asociar palabras relacionadas a lo que ofrece tu producto o servicio, para que al momento de redactar una frase o palabra que se asemeje al contenido relacionado al producto como en este caso lo es el condominio.

Entre las palabras clave que pueden ayudarnos a conseguir clientes que coticen, se encuentran:

- Villa el Salvador

- Condominio

- Condominio en villa el Salvador

- Villa del Atleta

- Condominio con gimnasio

- Juegos Panamericanos 2019

Y así colocar muchos más a nuestra disposición. Lo ideal de invertir en SEM es posicionarnos primero que cualquiera para poder contactarnos con un potencial comprador, a quien finalmente, después de aterrizar en nuestra Landing, le podrán ofrecer una asesoría personalizada que lo convenza. Se le destinará un $15 \%$ de nuestro presupuesto total a SEM para obtener resultados altamente positivos. 


\subsection{Segunda etapa: Medios Offline}

\subsubsection{BTL/ Volanteo}

Contrataremos una agencia que nos ayudará con el volanteo a través del anfitrionaje. A esta agencia le destinaremos un 3\% de todo nuestro presupuesto para estos 3 meses. A diferencia de los demás medios off-line, el Volanteo iniciará al mismo tiempo que la campaña digital para sumergirnos al mercado y generar awareness en las Zonas de Lima Sur aledañas a Villa El Salvador.

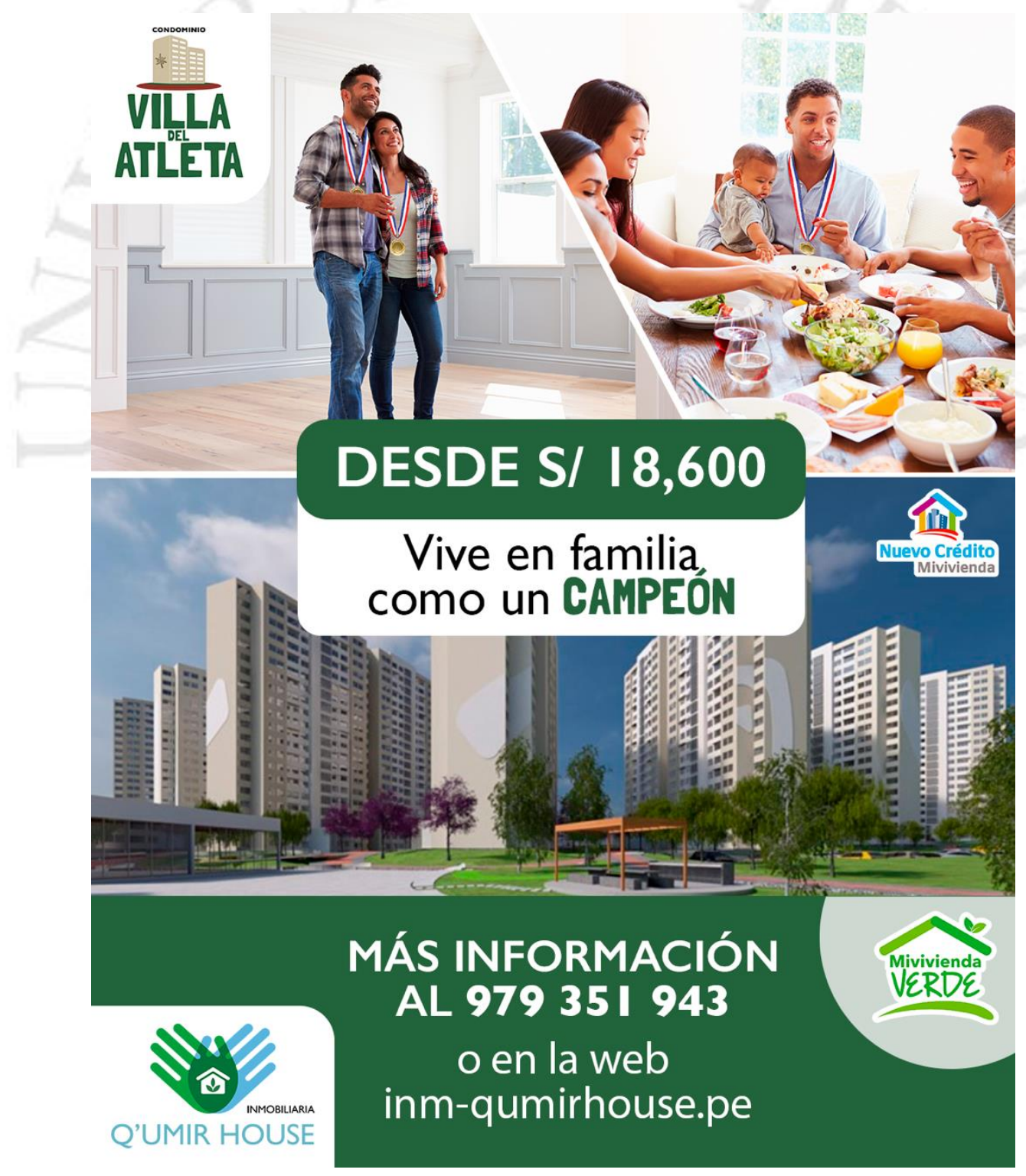

Ilustración: Flyer para volantear. Fuente: Propia. 


\subsubsection{Medios OOH}

En cuanto a los medios Outdoor, a los cuales se les destina un $4 \%$ del presupuesto total lo que significa cerca de $\mathrm{S} / 18,000$ invertidos, se quiere lograr posicionarnos en la mente del potencial consumidor gracias a buscar la visibilidad.

Queremos disponer de una Torre Minipolar en la zona de Lima Sur sobre todo cercana a Villa el Salvador y también queremos colocar un banner a lo largo de un muro que también pueda llamar la atención de nuestro Target. Además de ellos, tenemos presencia en un paradero y una paleta.

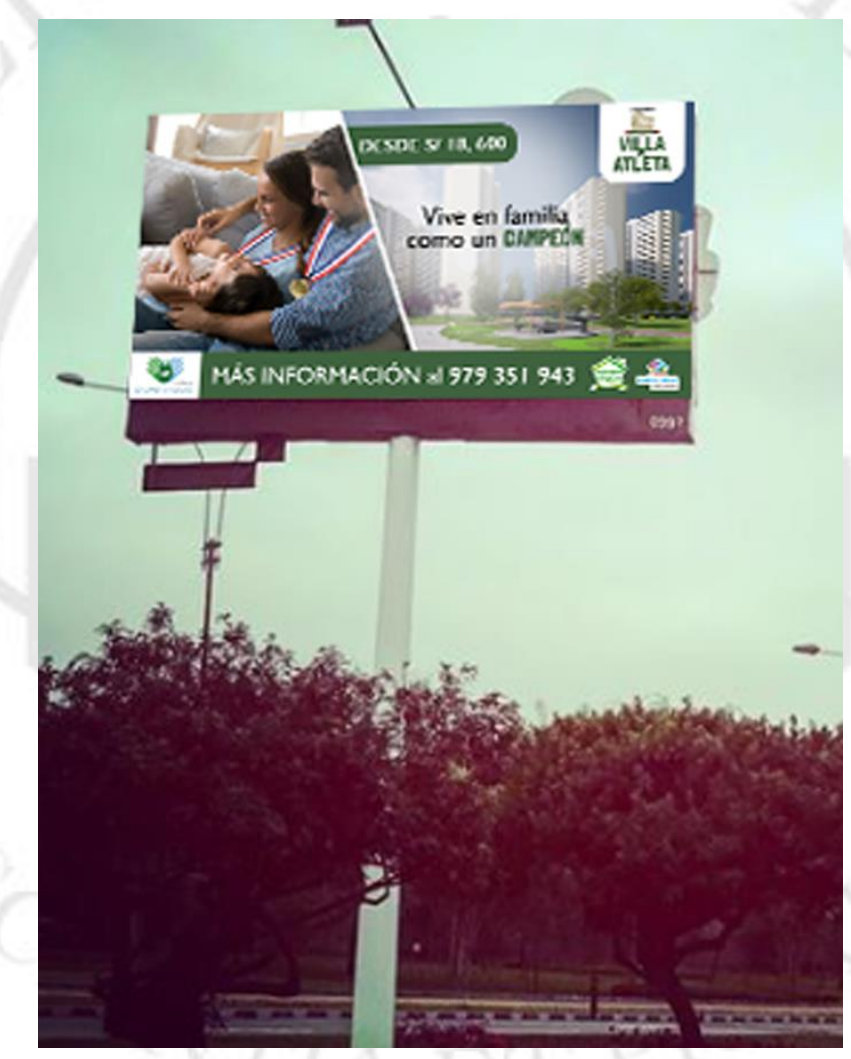

Ilustración: Torre Minipolar C. Fuente: propia. 


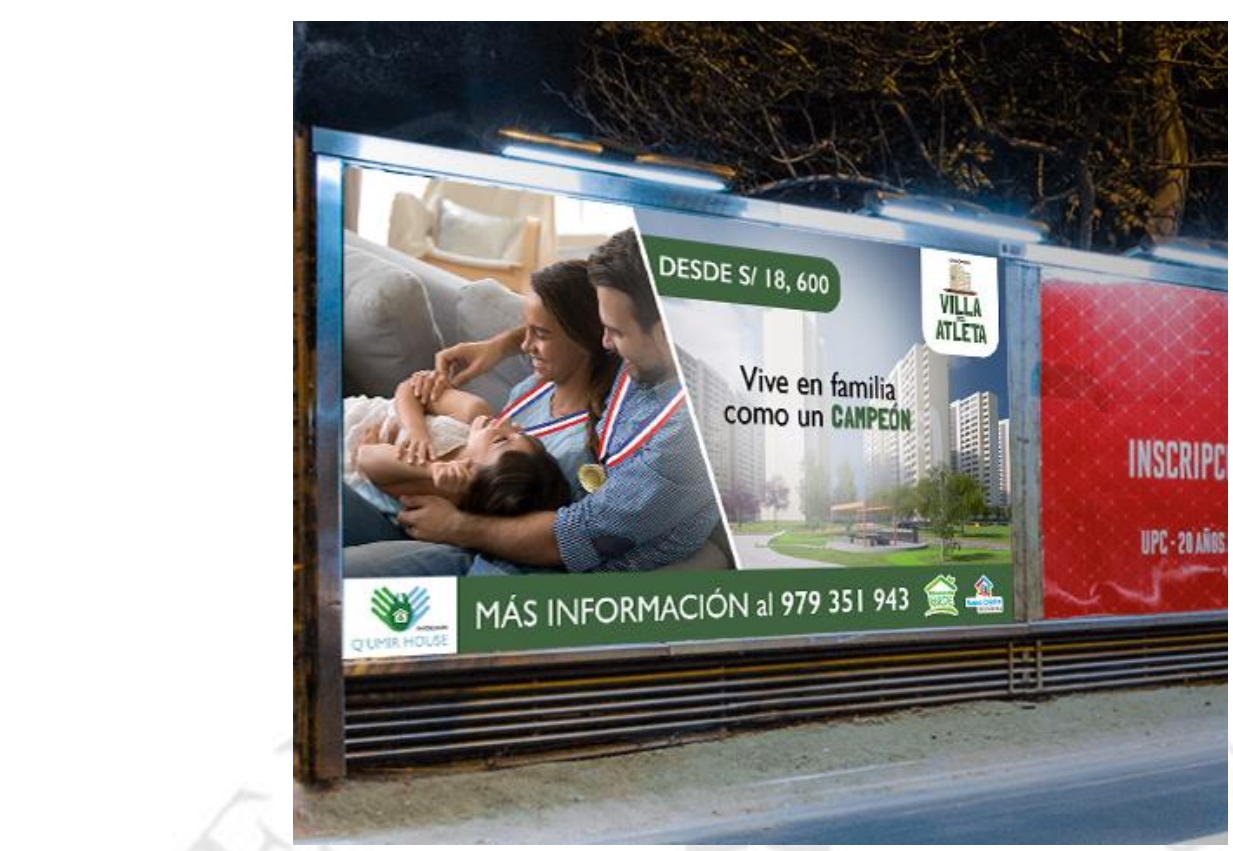

Ilustración: Muro o Valla al piso. Fuente: propia.

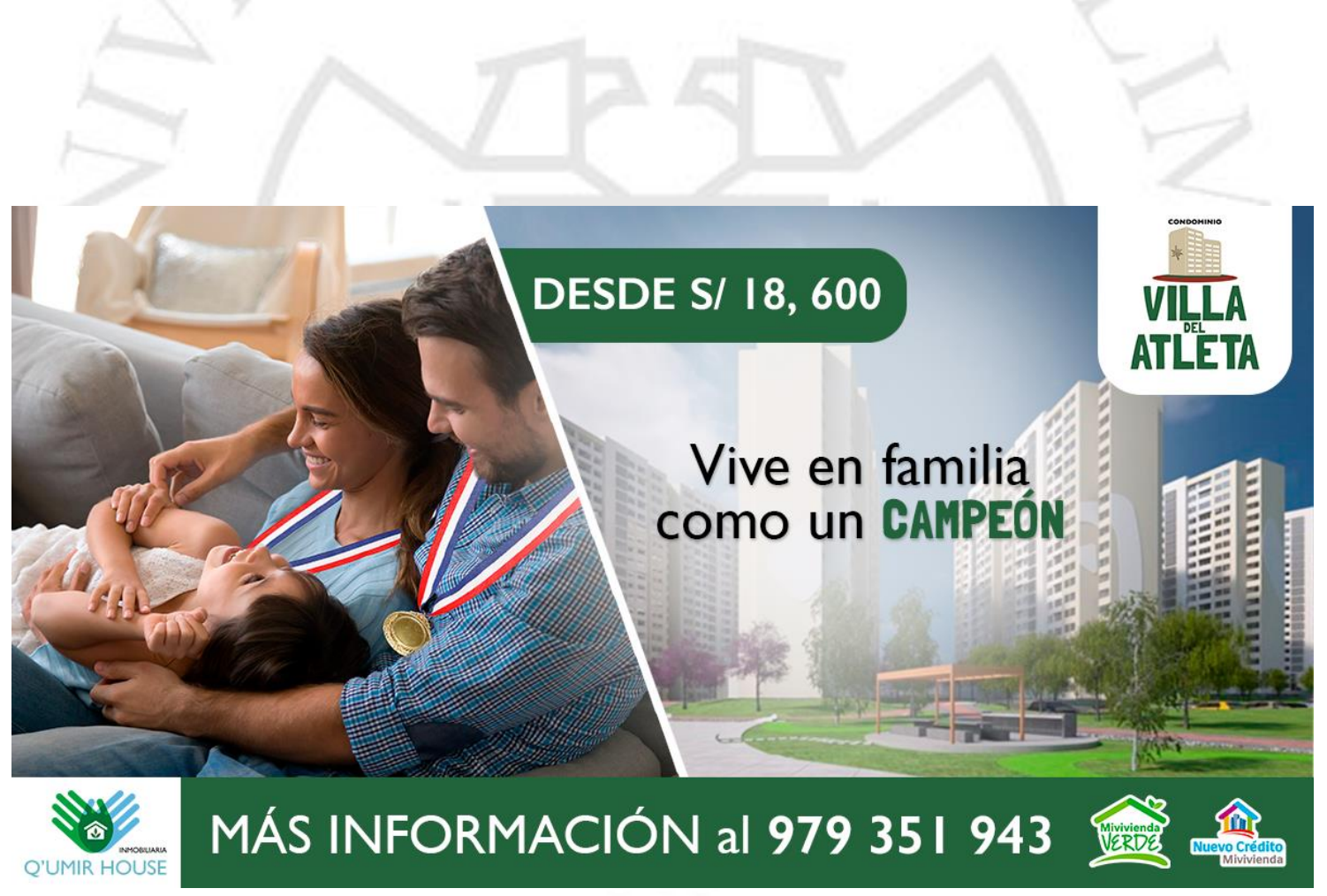

Ilustración: Arte de Valla al piso y Torre Minipolar. Fuente: propia. 


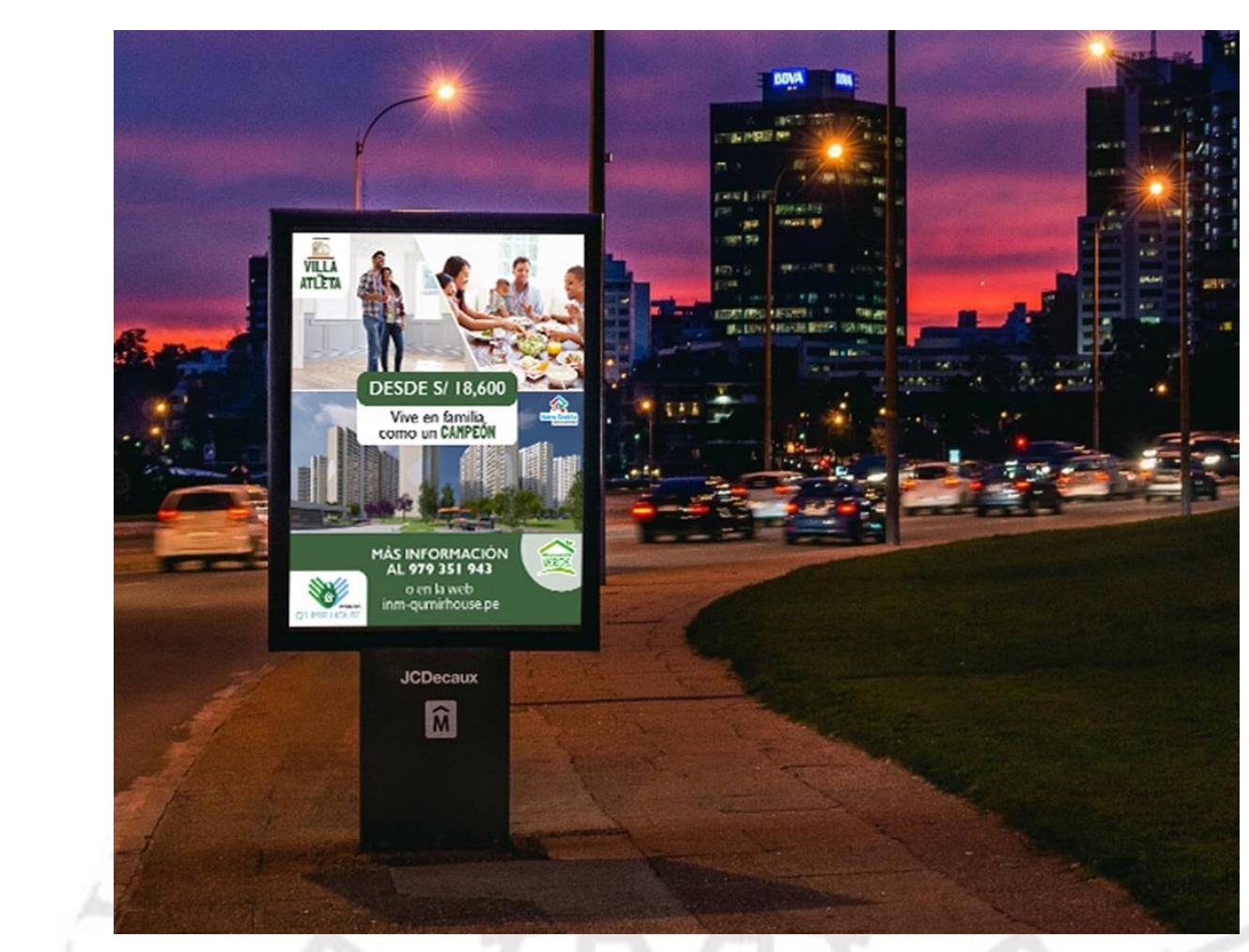

Ilustración: Paleta. Fuente: propia.

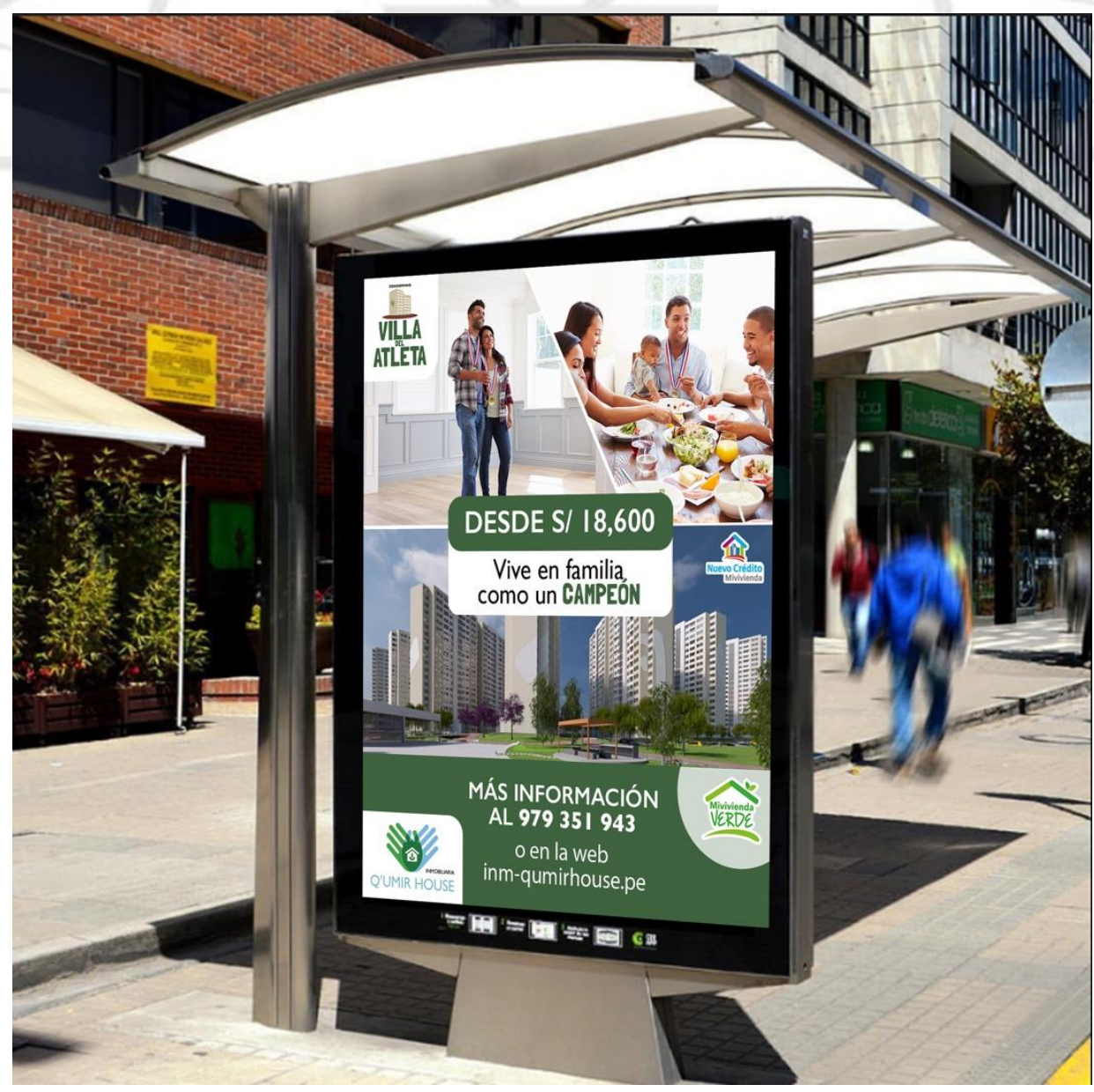

Ilustración: Paradero. Fuente: propia. 


\subsubsection{Radio}

Debemos tener en cuenta que nuestro público del nivel socioeconómico $\mathrm{C}$ y $\mathrm{D}$, muy aparte de encontrarse alineados a los medios digitales y hacer uso de los smartphones y pasar horas navegando diariamente por internet, también siguen creyendo en los medios tradicionales y le tienen un alto rango de credibilidad como anteriormente mencionamos que en el estudio de IPSOS del año 2017 llamado "Instituciones en las que más confían los peruanos". Es necesario hacer hincapie en que este estudio demuestra que la radio genera mayor credibilidad y confianza que la Televisión.

Asimismo, según el estudio del CPI sobre la Audiencia Radial Nacional (2018) se afirma que la Radio es un medio cuya masividad promueve efectividad, como lo expone la siguiente ilustración que recopila la CRP en su brochure de preventa 2019 basado en el estudio del CPI sobre la Audiencia Radial Nacional.

Más de $\mathbf{2 8}$ millones de peruanos la escuchan, en promedio, $\mathbf{2 3}$ horas a la semana. El consumo es segmentado, pues cada oyente elige el formato con el que más se conecta.

9 de cada 10 peruanos escuchan radio a la semana. ${ }^{3}$

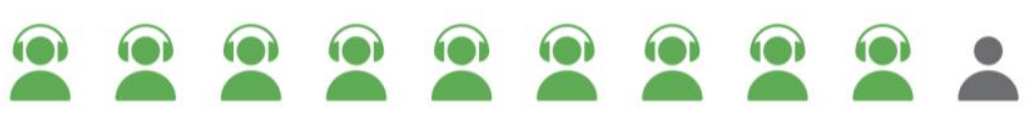

Consumo de radio. ${ }^{4}$

\begin{tabular}{|c|c|c|}
\hline Por sexo & Por NSE & Por edad \\
\hline $\begin{array}{l}\text { HOMBRE } \\
23 \text { h } 06 \text { min }\end{array}$ & $\begin{array}{l}\text { A - B } \\
19 \text { h } 27 \mathrm{~min}\end{array}$ & $\begin{array}{l}11-16 \\
16 \mathrm{~h} 12 \mathrm{~min}\end{array}$ \\
\hline $\begin{array}{l}\text { MUJER } \\
22 \text { h } 54 \text { min }\end{array}$ & $\begin{array}{l}\text { C } \\
22 \text { h } 24 \text { min } \\
\text { D - E } \\
24 \text { h } 51 \text { min }\end{array}$ & $\begin{array}{l}17-25 \\
20 \mathrm{~h} 03 \mathrm{~min} \\
26-37 \\
23 \mathrm{~h} 27 \mathrm{~min} \\
\mathbf{3 8}-\mathbf{5 0} \\
25 \mathrm{~h} 33 \mathrm{~min} \\
+51 \\
26 \mathrm{~h} 09 \mathrm{~min}\end{array}$ \\
\hline
\end{tabular}

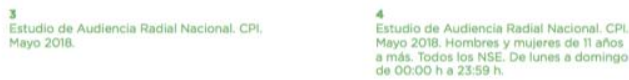

Fuente y elaboración: CPI (2018) 
Por ello es que añadimos un medio tradicional más a nuestro plan de comunicación: la radio y le dedicamos el $16 \%$ de nuestro presupuesto total. En cuanto a la radio, vamos a trabajar con la empresa CRP y hemos decidido colocar un anuncio publicitario de 20 segundos en Radio Moda.

¿Por qué nos basamos en radio moda si está posicionada como la radio de los jóvenes?

Porque después de RPP, Radio Moda es una de las emisoras radiales más escuchadas de todo el Perú y Lima metropolitana según el estudio del CPI sobre las Audiencia Radial Nacional, mencionada anteriormente.

\section{PERFIL DE AUDIENCIA}

MODA ES LA EMISORA QUE CONECTA TU MARCA CON LOS JÓVENES. TIENE UNA AUDIENCIA

ACUMULADA SEMANAL DE MÁS DE 3.86 MILLONES

DE OYENTES A NIVEL NACIONAL.

DISTRIBUCIÓN POR NSE 1

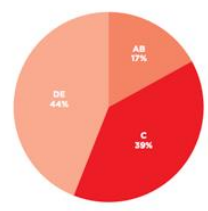

DISTRIBUCIÓN POR SEXO
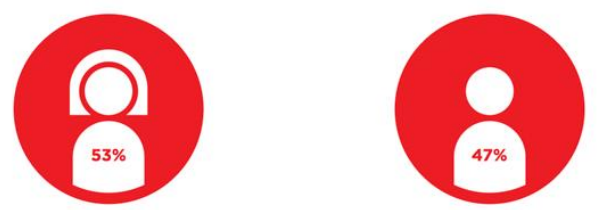

DISTRIBUCIÓN POR EDAD

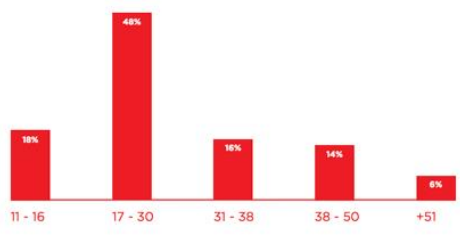

DISTRIBUCIÓN POR DISPOSITIVO²
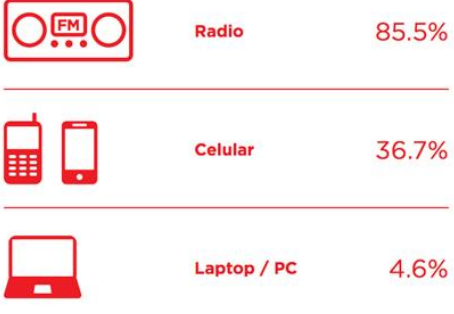
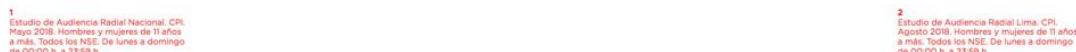

Fuente: CRP Brochure Preventa (2019) 


\section{AUDIENCIA ACUMULADA DE EMISORAS FM/AM}

- LIMA METROPOLITANA -

LUNES A DOMINGO DE 00:00 - 24:00 hrs.

GRUPO OBJETIVO: Hombres y mujeres de 11 años a más / NSE Total

UNIVERSO: 8527.4 (miles)

\begin{tabular}{|c|c|c|c|c|c|c|c|c|}
\hline \multirow{2}{*}{$\begin{array}{l}\text { R } \\
\text { K } \\
\text { G }\end{array}$} & \multirow{2}{*}{\multicolumn{2}{|c|}{ EMISORAS }} & \multicolumn{2}{|c|}{$\begin{array}{c}\text { AUDIENCIA } \\
\text { ACUMULADA SEMANAL }\end{array}$} & \multirow{2}{*}{$\begin{array}{c}\text { Horas y } \\
\text { minutos } \\
\text { escuchados } \\
\text { (Semanal) }\end{array}$} & \multicolumn{2}{|c|}{$\begin{array}{l}\text { AUDIENCIA ACUMULADA } \\
\text { PROMEDIO POR DÍA }\end{array}$} & \multirow{2}{*}{$\begin{array}{l}\text { Horas y } \\
\text { minutos } \\
\text { escuchados } \\
\text { (Por día) }\end{array}$} \\
\hline & & & Alc \% & Mls. & & Alc $\%$ & Mls. & \\
\hline \multicolumn{3}{|c|}{ Total audiencia acumulada } & 91.9 & 7838.6 & 21:51 & 74.6 & 6360.2 & 03:51 \\
\hline 1 & R.P.P. & FM/AM & 26.4 & 2248.7 & $07: 12$ & 11.8 & 1002.3 & $02: 18$ \\
\hline 2 & Moda & FM & 25.8 & 2204.1 & 06:00 & 9.8 & 836.0 & 02:15 \\
\hline
\end{tabular}

Fuente: CPI, Estudio de Audiencia Radial Nacional (2018)

Y como se puede visualizar en primera imagen sobre el perfil de la audiencia y su distribución por edad, no solamente los jóvenes consumen Radio Moda, sino también las personas con rangos de edades entre 31-38 y 38-50, así que, aunque no se tenga una preferencia alta en los adultos mayores, también les genera un interés y son consumidores de Radio Moda. Asimismo, el alcance que genera semanalmente entre todos los niveles socioeconómicos es uno de los más abundantes y Radio Moda es la radio top del CRP, con el más alto alcance de todas las que ellos poseen.

OYENTES A NIVEL NACIONAL

Público total

$3 \cdot 867,000 '$
semanalment

$176.8 \mathrm{mil}^{2}$ cada $1 / 2$ hora
Público objetivo

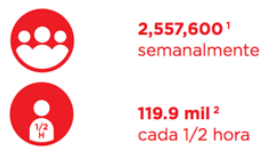

TOP 5 DE EMISORAS Comparativo de audiencia Lima

En miles de oyentes - $\mathrm{PO}^{4}$

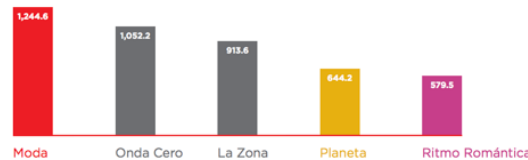

Fuente: CRP, Brochure Preventa (2019)

Este anuncio se reproducirá en las horas Premium del día, es decir entre 3:00 a 9:00 de la noche. A lo largo de tres meses, en distintas semanas, se reproducirá el anuncio pauteado.

En el primer mes se reproducirá el anuncio en las primeras tres semanas. En el segundo mes, se reproducirá el anuncio la segunda semana y la cuarta semana. Por último, en el tercer mes, el anuncio será reproducido en la semana 1, 3 y 4.

¿Por qué decidimos alternar la rotación de los anuncios? 
Se decide alternarla para evitar saturar al oyente y, en las semanas que se le destina una pausa, generar cierta intriga. Esto ocasionará que la persona interesada que no pudo obtener una cita por más que le interesó lo que ofrecía el condominio, en ese momento, al enterarse que estén disponibles no lo pensará dos veces y esta vez sí concretará la cita y posteriormente una venta.

\subsubsection{Guión de radio}

Para el planteamiento del guión que se narrará en el anuncio, se propone lo siguiente:

“(efecto de sonido de alerta) Esto no es un simulacro (efecto reverb), ¡Ahora podrás tener el depa que TANTO soñaste en el condominio Villa del atleta! El mejor lugar para vivir acompañado de tu familia como TODO un campeón.

Separa tu cita hoy al 979351943.

Porque nosotros pensamos en tu tranquilidad"

Cabe destacar que a las palabras que se encuentren en mayúscula se les dará cierto énfasis al momento de narrarlas. Además, la frase "esto no es un simulacro" tendrá un efecto reverb de estudio conocido como "reverb de voz media". Posteriormente la narración transcurrirá normal con una música de fondo alegre, y un beat positivo, que genere motivación y se le asocie con un entorno de familiaridad. Nosotros como la Inmobiliaria Q'umir House contamos con un locutor interno que prepara los anuncios radiales para proyectos grandes que busquen resultados en corto plazo.

En el siguiente link podrán escuchar el audio base del anuncio: https://drive.google.com/open?id=103FzT0697tmqz2ZnZxTL7zlhhkr8-z3m

\subsubsection{Prensa}

Por último pero no menos importante, utilizaremos el recurso del periódico tradicional por tres meses. Estaremos en la prensa los fines de semana de todo el mes de febrero, marzo y abril, en la página número 13 del periódico Trome en un reducido espacio, pero 
que ayudará a generar Awareness y conocimiento de los departamentos que se encuentran en alquiler.

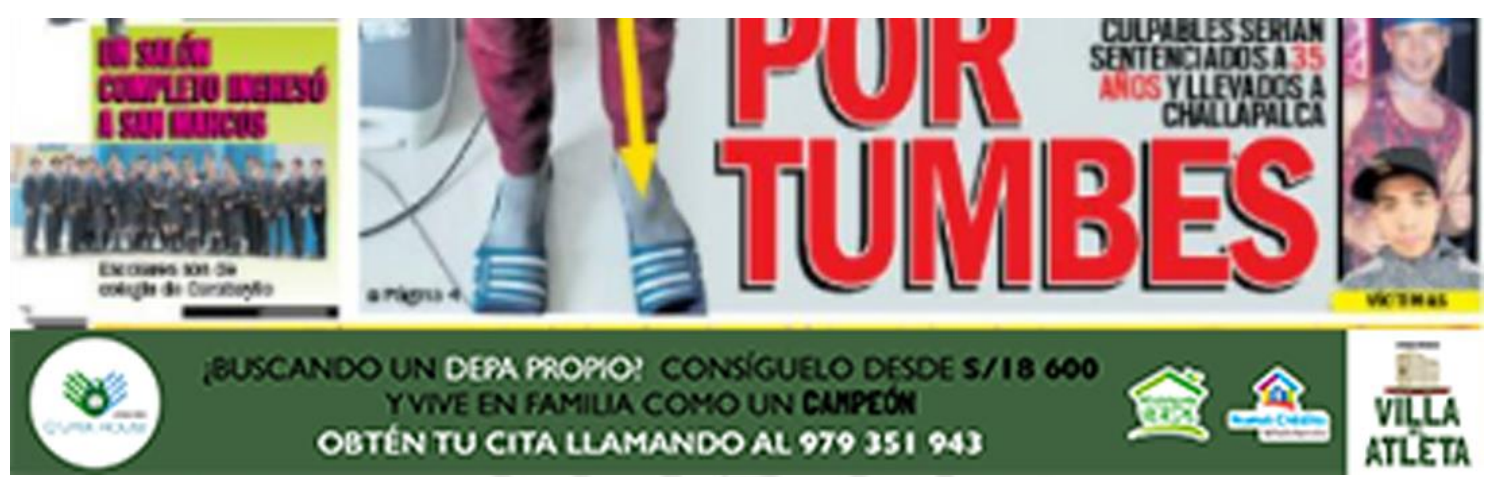

Ilustración: Prensa el Trome. Fuente: Propia.
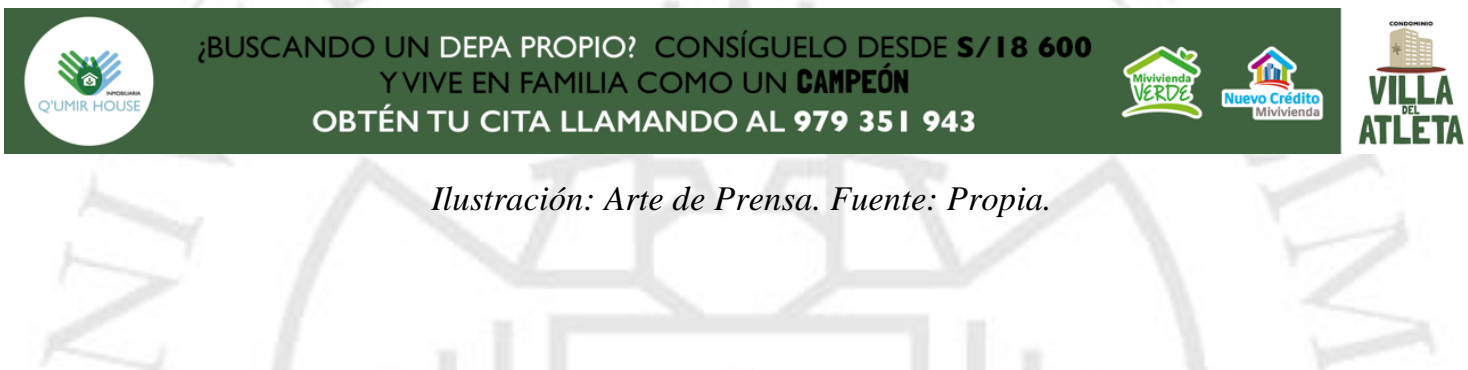

Para mayor explicación y desglose del Presupuesto en cuanto a los meses/semanas, este es el link:

https://drive.google.com/open?id=1MubnJ_Iv9GCIrNLgdKukcp__7ukDpEby 


\section{Sustentación de presupuesto}

Es importante resaltar la distribución de presupuesto que se realizó para esta campaña para poder entender cómo se alinea a los objetivos. Los medios online representan, la mayor parte de la inversión con un 59\%, ya que, como anteriormente cité a IPSOS en un estudio del 2018 sobre hábitos y usos del internet, demuestra que ahora las compras online son mayores.

Además, es muy importante tener claro que si a nuestro público objetivo lo estamos persuadiendo en su día a día con anuncios en distintos tipos de medios y que tenga a su alcance, al menos la curiosidad se habrá despertado y con ello, es probable que se consiga hasta una cotización y se logre concretar una venta.

La razón por la cual no vimos tan necesaria la participación de TV dentro del mix de medios, sin considerar el presupuesto que teníamos, se desistió porque es un medio que no garantiza una venta, al momento de querer vender una vivienda, lo que se busca es que el target interactúe contigo, quiera cotizar, quiera hacer una visita al departamento, conocer más a profundidad la infraestructura, etc.

\section{Conclusiones}

El condominio Villa del Atleta es una propuesta de complejo habitacional que tiene características que ahora se podrían llamar indispensables en nuestros tiempos. Es un condominio dedicado más que nada, al deporte, al preservar la salud y a convivir en un ambiente seguro y familiar.

Asimismo, estos departamentos se venderán lo más pronto posible debido a cómo repercutió positivamente el evento deportivo de los Juegos Lima 2019. Demuestra ser parte de una infraestructura dedicada, que tienes espacios y dormitorios especiales para personas con discapacidad. Todo el plan de comunicación buscará conseguir la venta total del condominio a través de la comunicación de sus facultades. 
Cabe resaltar que todo el plan se encuentra desarrollado en cuanto a propuestas, debido a que los medios puede que no cuenten con capacidad para aportar su granito de arena o puede que se cobre un precio mucho menor o nos oferten un beneficio aún más interesante. Los medios siempre cuentan con variables numéricos de precio y de resultados.

\section{RECOMENDACIONES}

Recomendaría poder tener un par más de animaciones que respalden nuestro presupuesto dedicado a los medios digitales. Si se tiene un video que realmente impacte, este puede generar una mayor cantidad de leads que lleven a cotizar y por ende, que los clientes compren. De repente se pudo también idear, mostrar las áreas de los departamentos del condominio para que el target no solo tenga en cuenta los beneficios sino también el valor agregado que brinda su espacio habitacional.

El excel de presupuesto denota un estimado de los montos que se suelen cobrar por medio, sin embargo, suele ser una variable que se encuentra en constante cambio. 


\section{REFERENCIAS}

-Blanco R. (2018) Cómo vender al cerebro, neuromarketing aplicado. Recuperado de: https://es.scribd.com/book/393945399/Como-vender-al-cerebro-neuromarketingaplicado

-BBVA Reseach. (2019). Mercado de viviendas nuevas y oficinas prime en Lima Metropolitana. Recuperado de: https://www.bbvaresearch.com/wpcontent/uploads/2019/03/MercadoViviendasNuevas_OficinasPrime_Lima.pdf?fbclid=I wAR0jZ9a5TQMZEv74Gj1Aodm9VUPFhR7CraOMBe4phhYGnC-zJ-vmLnuXclM

-Chapman (2010). Color Theory for designers, part 1: the meaning of color. Recuperado de: https://www.smashingmagazine.com/2010/01/color-theory-for-designers-part-1-themeaning-of-color

-Congreso del Perú (2016) Proyecto de ley N`3609, ley que incorpora el derecho a una vivienda digna. Recuperado de: http://www.leyes.congreso.gob.pe/Documentos/2016_2021/Proyectos_de_Ley_y_de_R esoluciones_Legislativas/PL0360920181107..PDF

-CPI Perú. (2018). Audiencia Radial total Perú: Urbano y rural - mayo 2018. Recuperado de:

https://cpi.pe/images/upload/paginaweb/archivo/26/mr_total_peru_radio_audiencia_201 $\underline{8 . p d f}$

-CRP Radios (2018) Brochure Preventa. Recuperado de: http://www.crpweb.pe/wpcontent/uploads/2018/12/1545946540_brochure-preventa-2019.pdf

-Datum Internacional. (2018). Vida saludable ¿Yo? Recuperado de: http://www.datum.com.pe/new_web_files/files/pdf/Vida-Saludable.pdf

-Fondo Mi Vivienda. (2006) Ley $\mathrm{N}^{\circ}$. 28579. Recuperado de: https://www.mivivienda.com.pe/portalweb/fondo-IVIVIENDA/pagina.aspx?idpage=3 
-Heller E. (2015) Psicología del color. Como actúan os colores sobre los sentimientos y la razón. Recuperado de: https://es.scribd.com/book/317029629/Psicologia-del-color$\underline{\text { Como-actuan-los-colores-sobre-los-sentimientos-y-la-razon }}$

-IPSOS Perú (2018). Hábitos del internet. Recuperado de: https://www.ipsos.com/sites/default/files/ct/publication/documents/2018-

10/habitos_del_internet.pdf

-LuJhon. (2019) Estadisticas consumo digital 2019 Perú. Recuperado de: https://lujhon.com/estadisticas-consumo-digital-peru-2019/

\section{ANEXOS}

- Dirección web de piezas de comunicación:

https://drive.google.com/open?id=1otUKSm5YFjyPfraY1aK9tLiCq38aEw6o

- Dirección web de tablas de excel:

https://drive.google.com/open?id=1T2-JxWw3BFJMLa-UAysEOXPdhoOkOk4q

- Encuesta a público objetivo: 16 personas- 8 hombres/8 mujeres

1. Sexo:

- Masculino

- Femenino

2. Edad

$-25-35$

$-35-45$

$-45-55$

3. ¿Seguiste los Juegos Panamericanos y Parapanamericanos Lima 2019?

$-\mathrm{Si}$ 
- No

- Muy poco

4. Si tuvieras la oportunidad, ¿vivirías en el condominio que hicieron especialmente para albergar a los deportistas de distintos países?

- Sí

- No

5. ¿Por qué?

6. ¿En qué tipo de vivienda vives?

- Alquilada

- Vivo con familiares

- Propia

7. En caso tu vivienda no sea propia, ¿te gustaría tener una?

$-\mathrm{Si}$

$-\mathrm{No}$

8. ¿Cuántos cuartos te gustaría que tenga?

$-1$

$-2$

$-3$

$-4$

9. ¿Qué valoras más al buscar una vivienda? Explica, puedes dar varios argumentos. 
10. ¿Cuáles consideras valores agregados que pueda tener una vivienda a tu disposición? (PUEDEN MARCAR VARIAS OPCIONES)

-Zonas de entretenimiento

-Seguridad

-Cercanía a avenidas

-Cercanía a centros comerciales

-Reconocimiento del lugar

-Precio

-Espacio

11. ¿Conoces el Nuevo Crédito Mi Vivienda?

$-\mathrm{Si}$

-No

-He escuchado de él pero no sé cómo funciona -Lo he utilizado

12. Con el Nuevo Crédito Mi Vivienda podrías financiar hasta el $90 \%$ del precio tu casa o departamento. ¿Te interesaría postular?

$-\mathrm{Si}$

$-\mathrm{No}$ 